تأثثير عو امل الفعالية الإعلانية على سلوك التكافل الاجتماعي

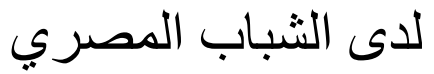

\author{
دراسة تطبيقية على إعلانات المؤسسات الخيرية
}

\title{
د/هالة الطحاتي"
}

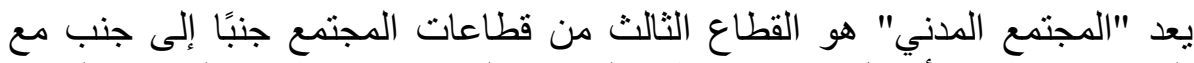

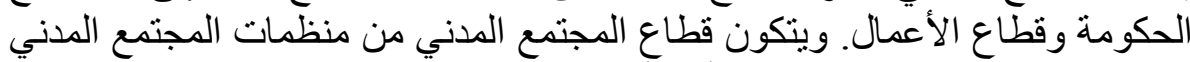

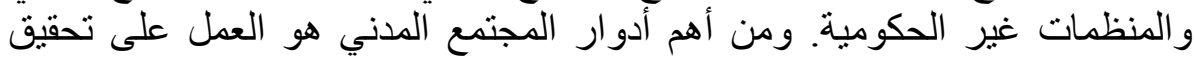

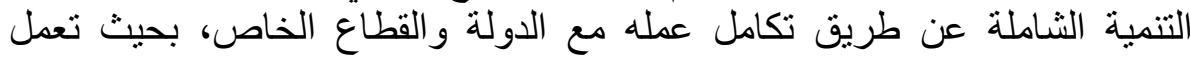

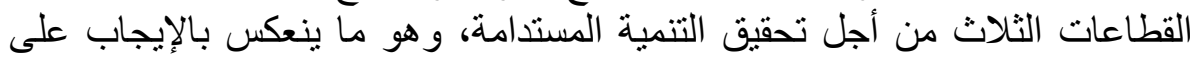

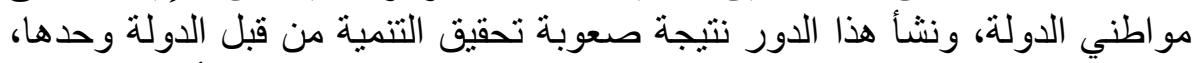

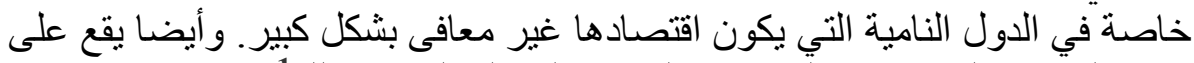

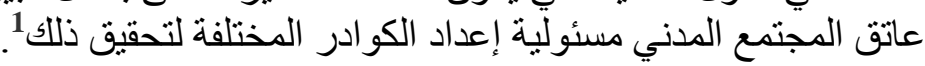

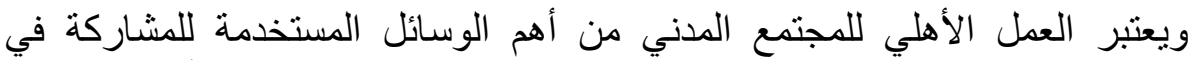

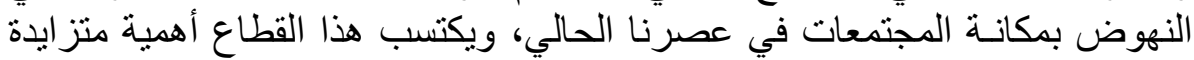

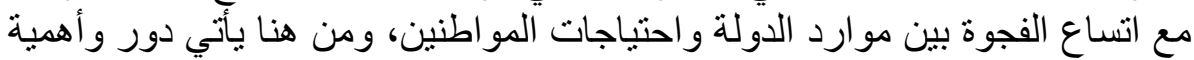
المنظمات الأهلية لتكن بمثابة شريك في التنمية المستدامة، وتساند الدولة التئ في تللية احتياجات المو اطننين.2

ويعتمد المجتمع الددني في أنشطته وفي تحقيق أهدافه على وسائل الإعلام للوصول

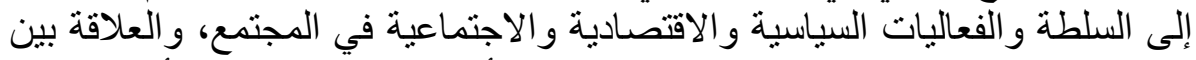

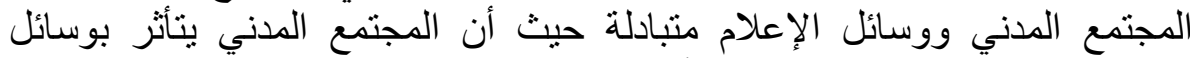

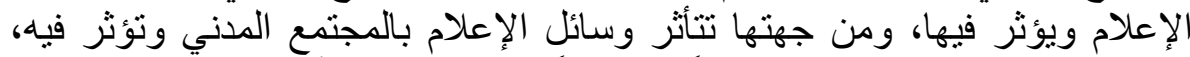

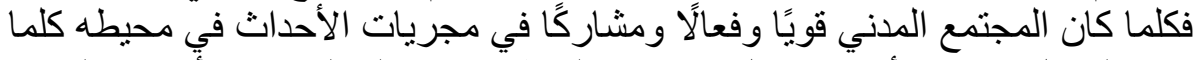

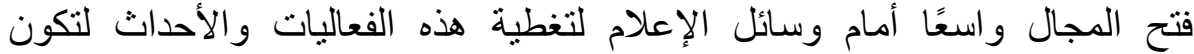

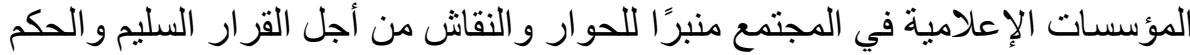

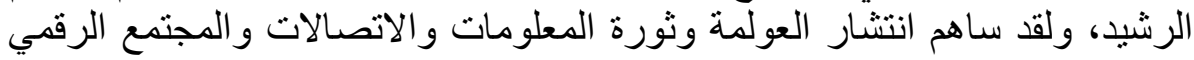

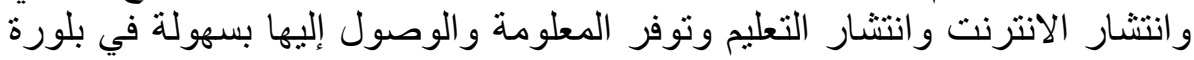
ونضج فكرة المجتمع المدني في الوطن العربي التربي.

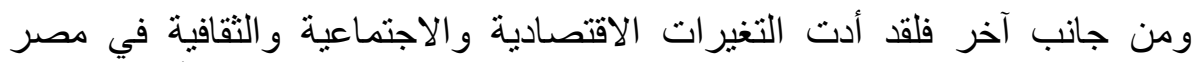

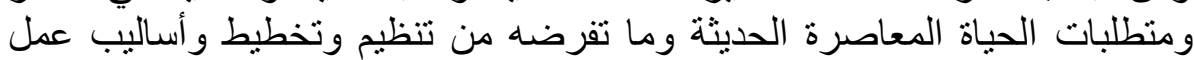
مبتكرة إلى تحول العمل الاجتماعي التطوعي من صيغتنه و أنماطه التقليدية السابقة إلى على

* مدرس بقسم العلاقات العامة والإعلام بكلية الإعلام - الجامعة الحديثة للتكنولوجيا والمعلومات. 


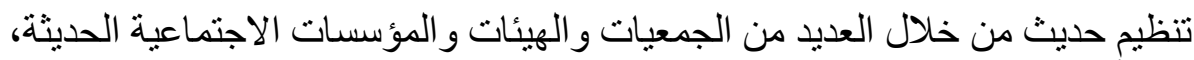

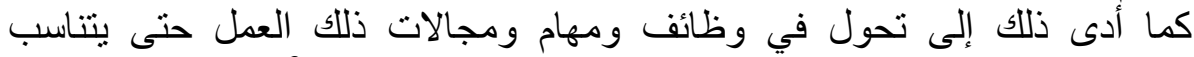

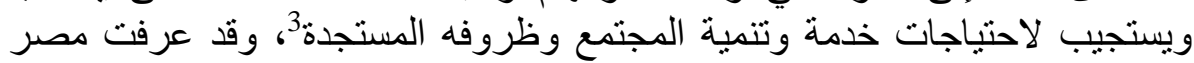

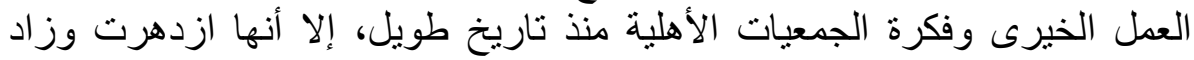

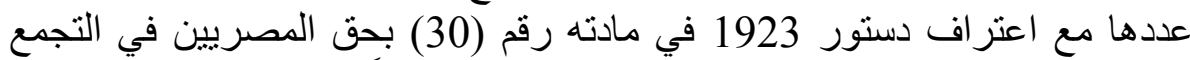

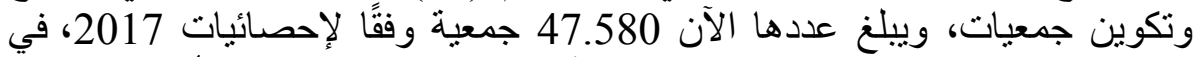

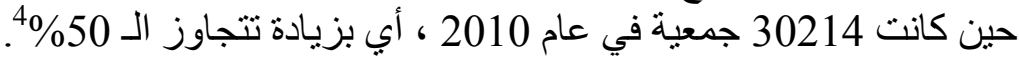

و هناك مسئولية كبيرة تقع على عائق مؤسسات المجتمع المدني إلا وهي المشّاركة في

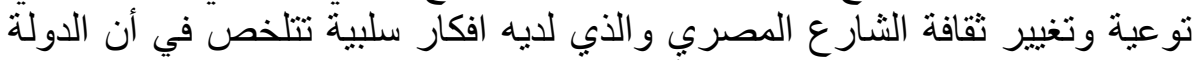

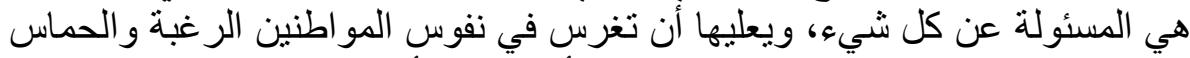

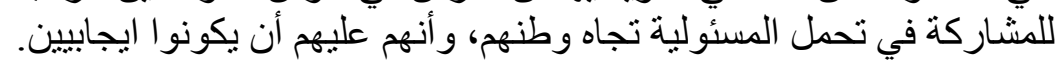
وتعتبر الإعلانات سواء كانت المقروءة أو المسموعة أو المرئية وسواء تم مشاهدتها

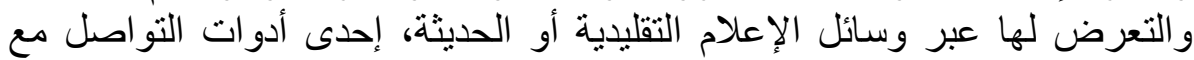

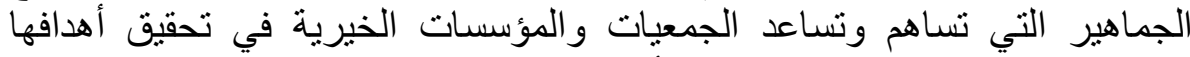

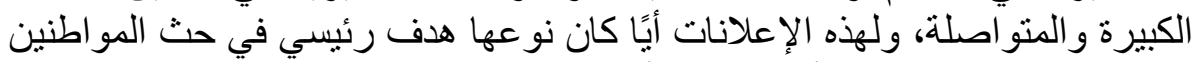

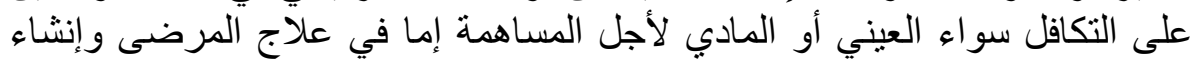
المستشفيات، والبحث أو إنقاذ الأفراد الفقراء من الحاجية الحاجة، أو تحسين البنية التحتية

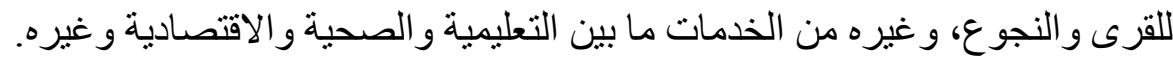

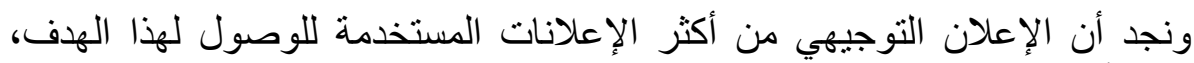

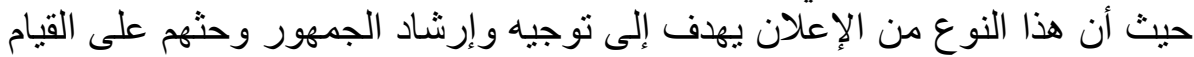

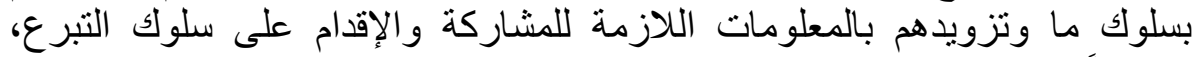

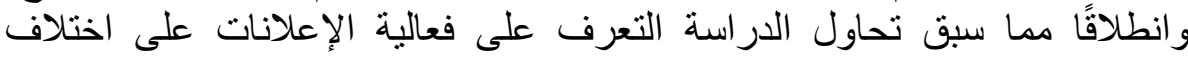

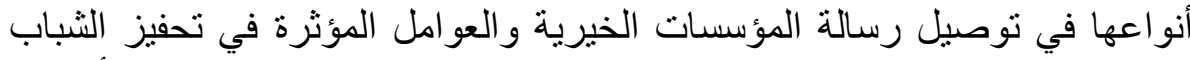

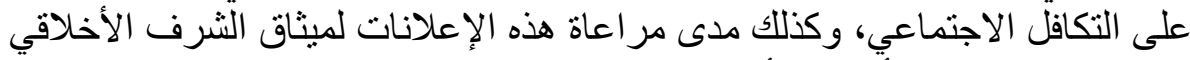

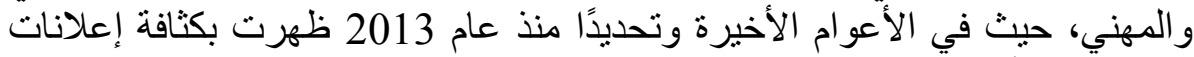

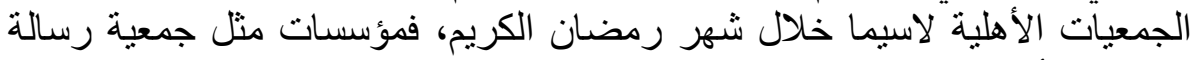

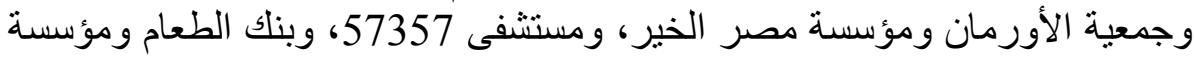

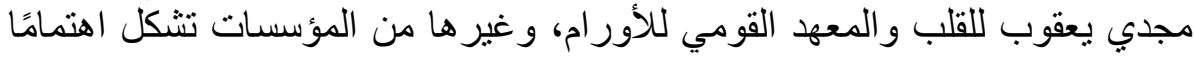

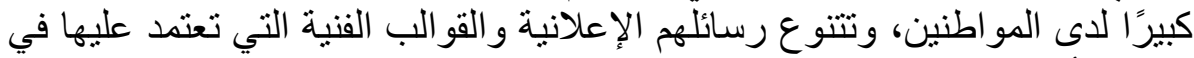

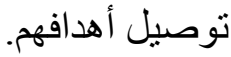

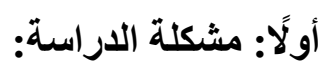
أكدت العديد من الدراسات على أهمية تحمل الجمعيات الأهلية لدور ها في التصدي لألهاي

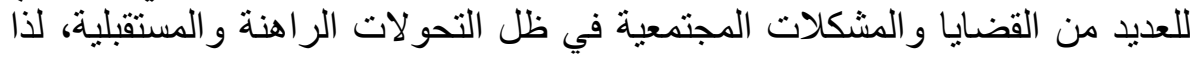


تتصاعد أهداف إعلانات الجمعيات الأهلية بغية التعريف بأنشطتها و إنجاز اتها أو حث

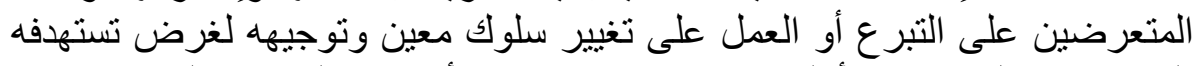

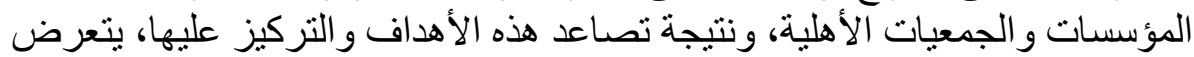

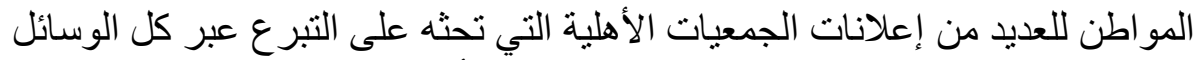
الإعلامية وخاصة القنوات الفضائية المختلفة، التي أصبحت الصنية تستهدف جميع التيع الثرائح حتى المواطن البسبط.

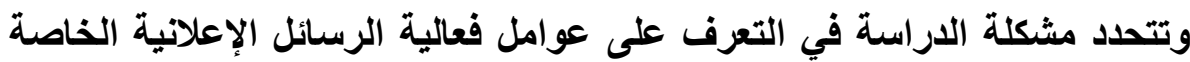

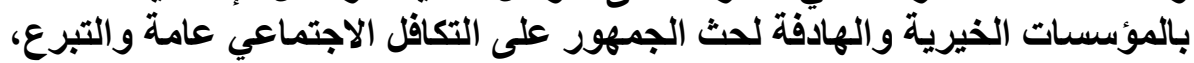

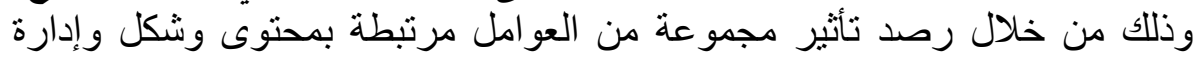

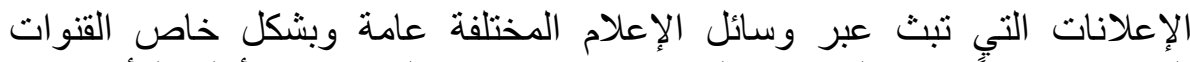

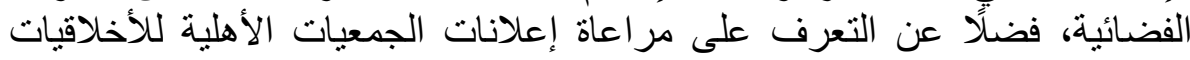

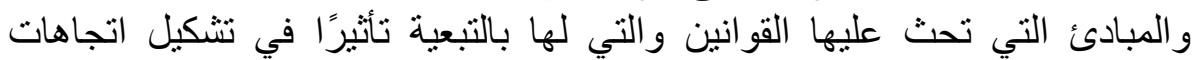
المشاهد وحثه على التبر ع لهذه المؤسسات الخيرية.

ثانيًا: أهمية الاراسة: وتأتي أهمية الدراسة من خلال العديد من النقاط كالآتي:

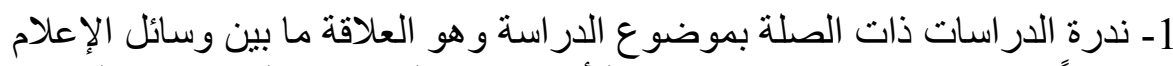

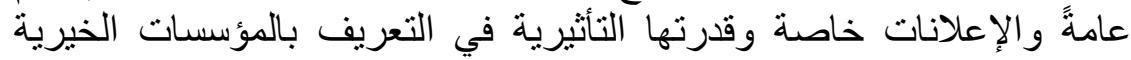

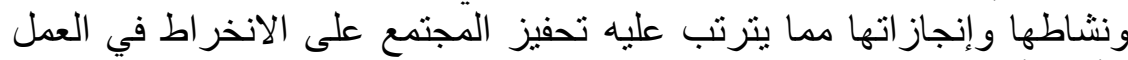

$$
\text { الأهلي أو التطوعي. }
$$

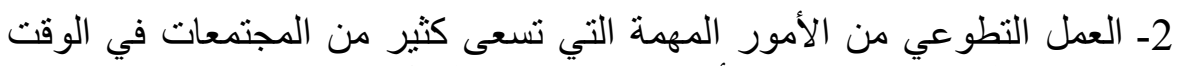

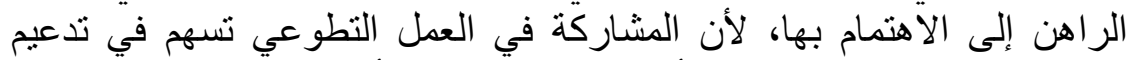

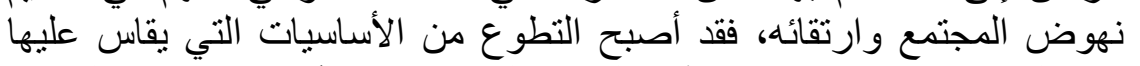

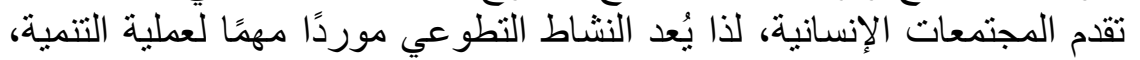

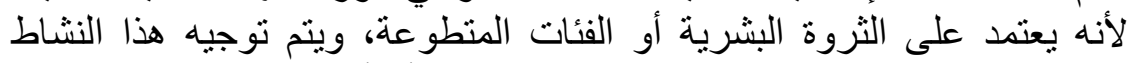

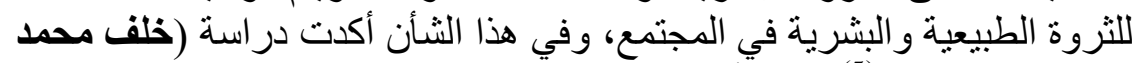

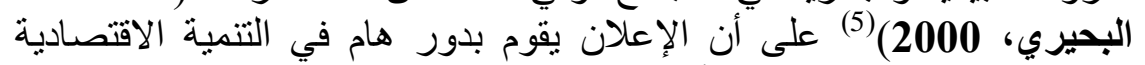

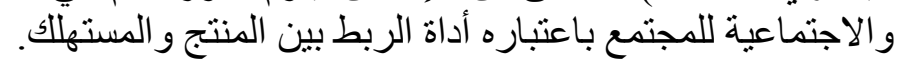

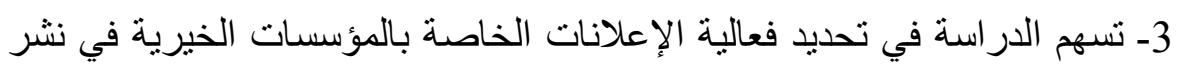

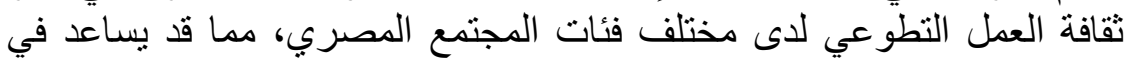

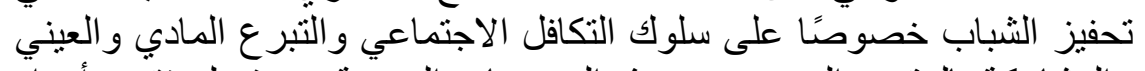

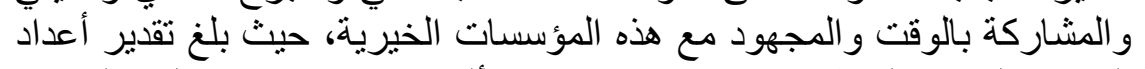

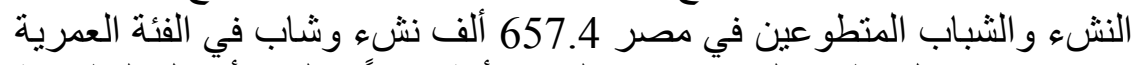

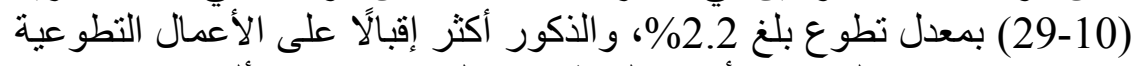

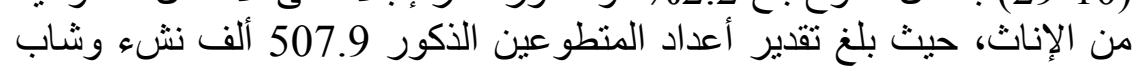


بمعدل تطوع 3.3\%، بينما بلغ تقدير أعداد المتطوعات من الإناث 149.5 ألف

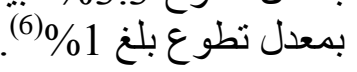

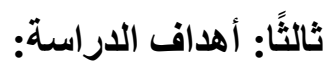

1- تحديد أهمية دور الإعلام في مجال عمل المؤسسات الخيرية.

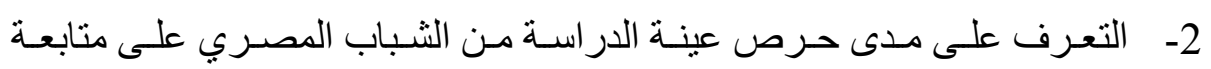

الإعلانات التليفزيونية الخاصة بالمؤسيسات الخيرية.

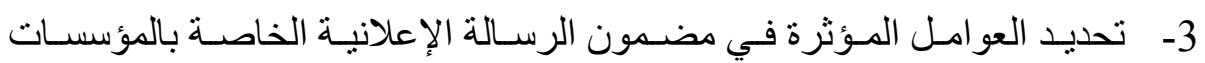

الخيرية.

4- تحديد العو امل المتعلقة بإدارة الرسالة الإعلانية الخاصة بالمؤسسات الخيرية.

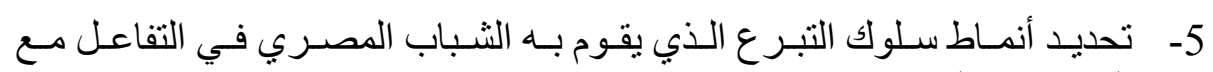
المؤسسات الخيرية.

6- تحديد تأثير الفعاليـة الإعلانيـة على سلوك التبرع تـأثرًا بالإعلانـات التليفزيونية الخاصة بالمؤسسات الخيرية.

رابعًا: الدراسات السابقة:

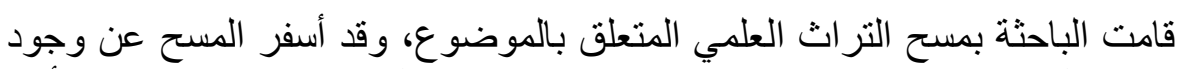

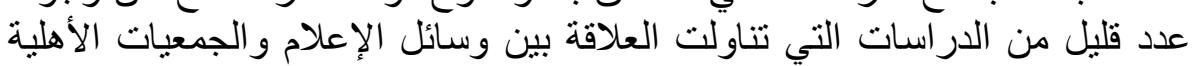

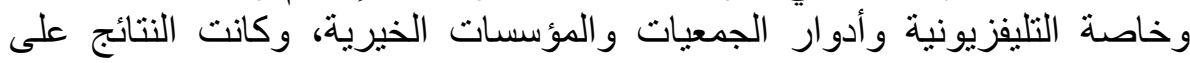
النحو التالي:

الحملات الإعلانية التليفزيونية لمستشفى سرطان الأطفال في مصر وتأثيراتها

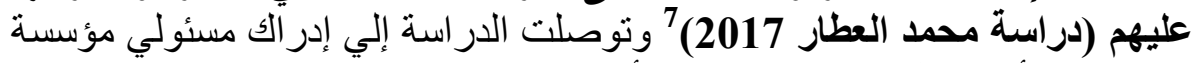

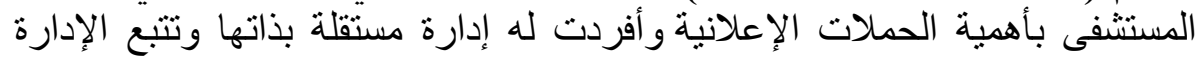

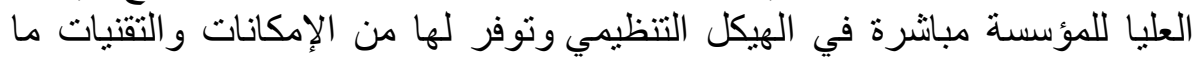

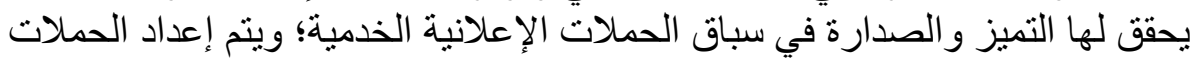

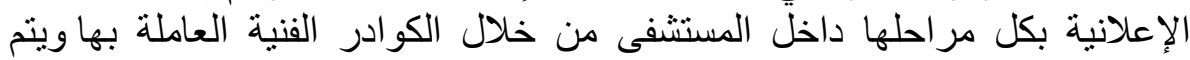

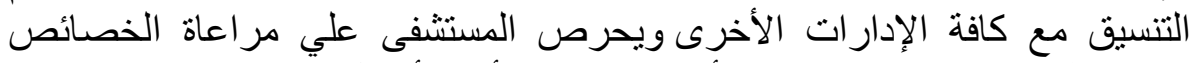

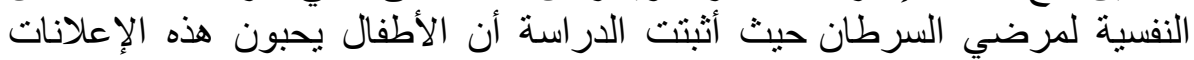
ويحرصون علي المشاركة فيها ومتابعتها.

وعن "حملات التسويق الاجتماعي في وسائل الإعلام الإكترونية ودورها في في فئي

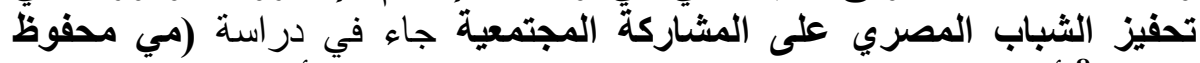

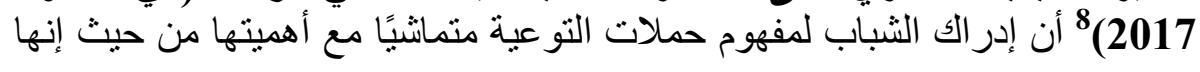


مجمو عة من الممارسات و السياسات و البر امج تتكامل استر اتيجيًا في جميع أنشطتها

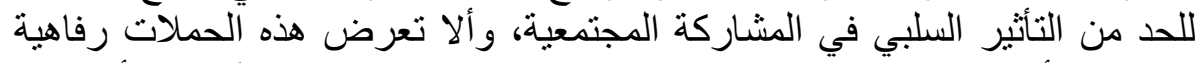

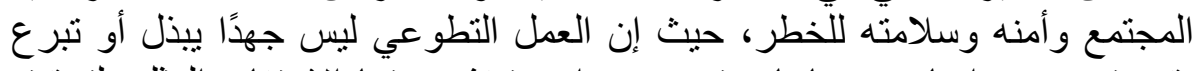

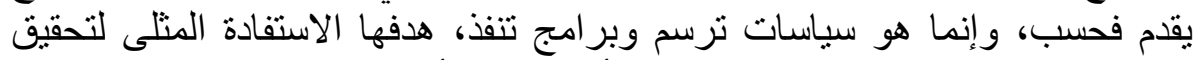

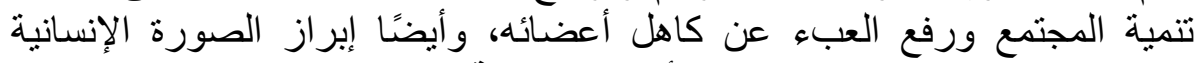

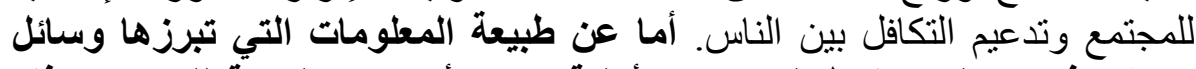

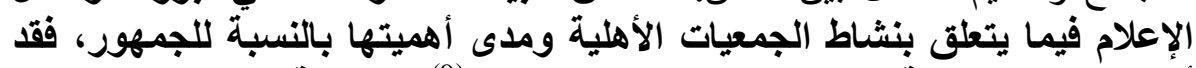

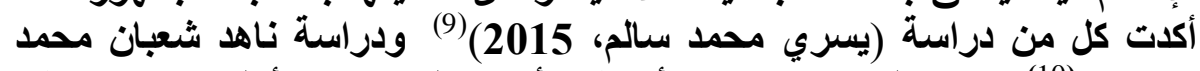

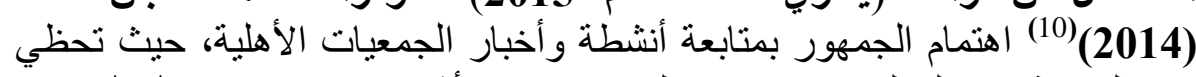

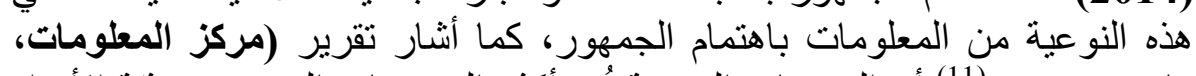

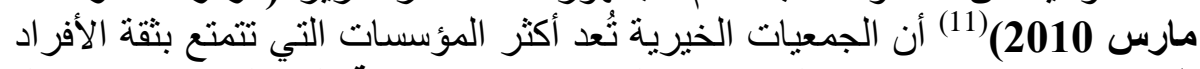

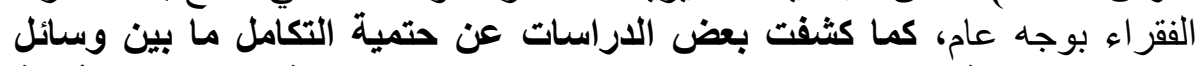

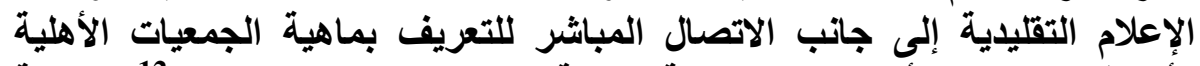

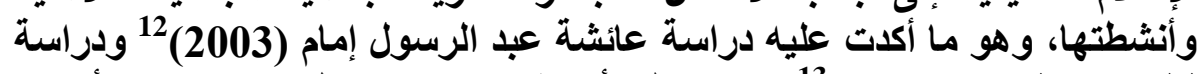

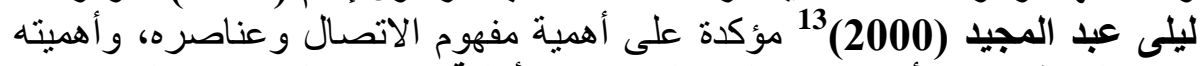

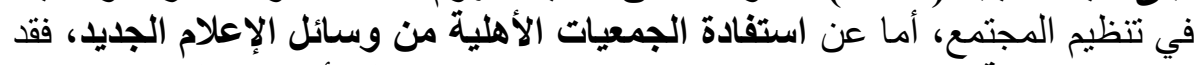

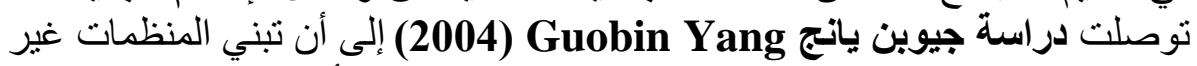

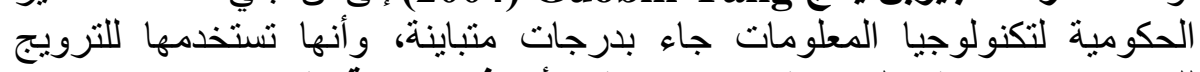

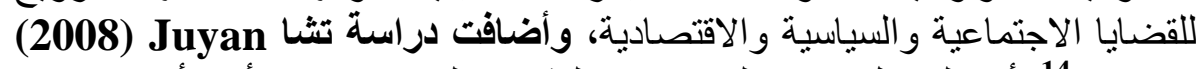
14 Zhang الجمعيات الأهلية.

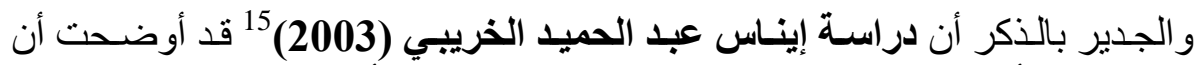

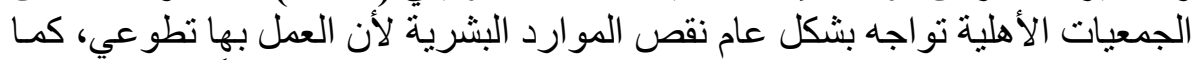

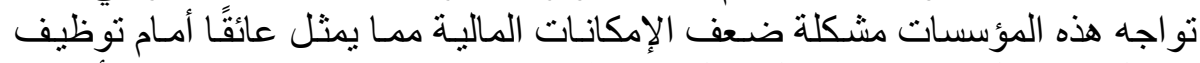

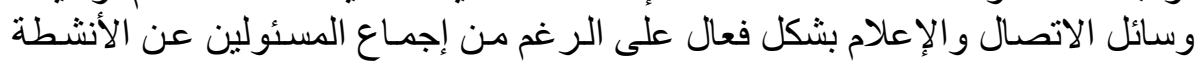

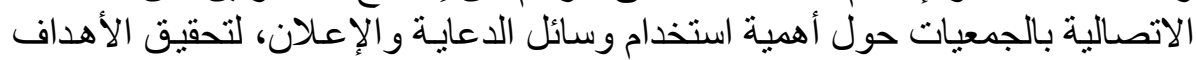

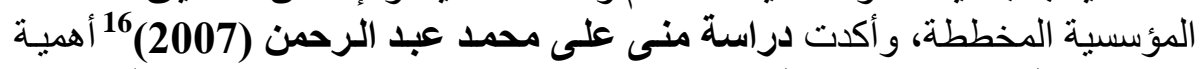

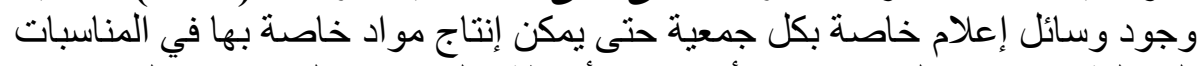

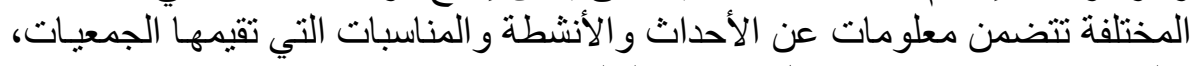
و التي يتم فيما بعد إمداد وسائل الإعلام التقليدية بها. أهم التعليقات على الاراسات السابقة:

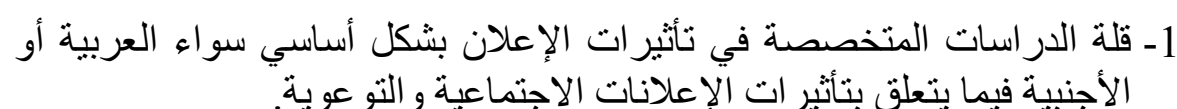


2- غلبة البحوث الوصفية التحليلية والميدانية وندرة البحوث التجريبية، لذا يرتفع استخدام منهج المسح بالعينة، والتي غلب الته عليها صغر حجم عيناتها.

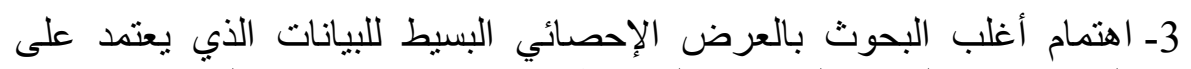

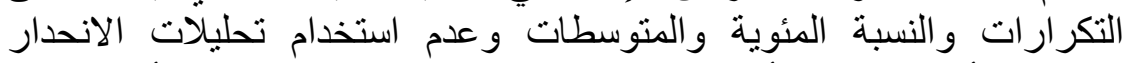

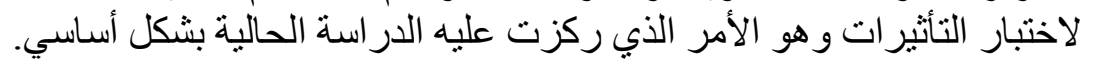

\section{خامسًا: الإطار المعرفى:

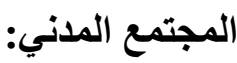

بيتشكّل المجتمع المدني من المؤسسات والجمعيات الأهلية، غير الحكومية، المعتمدة

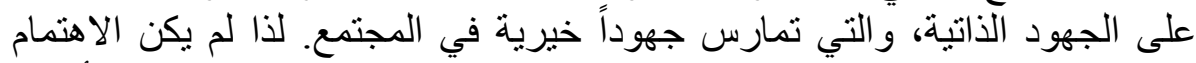

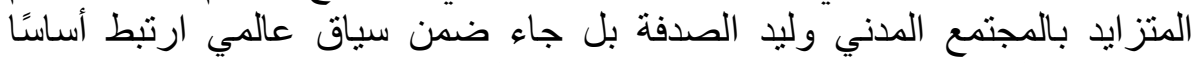

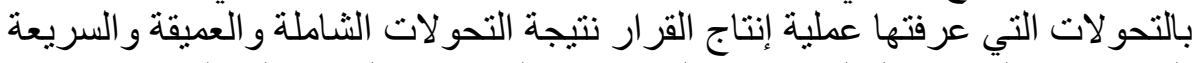

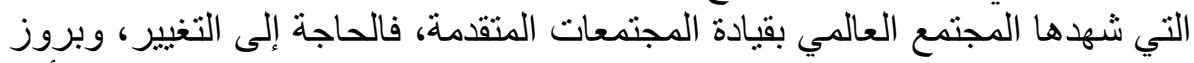

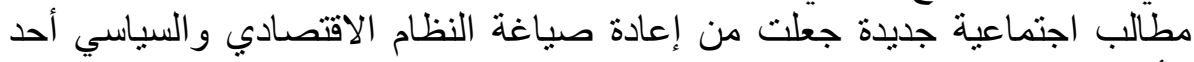

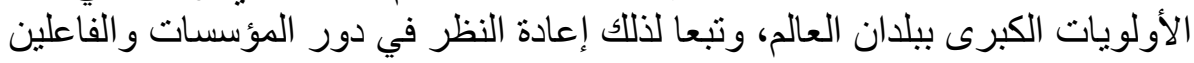

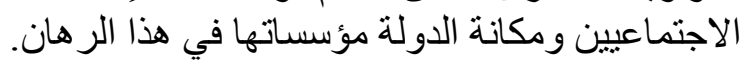

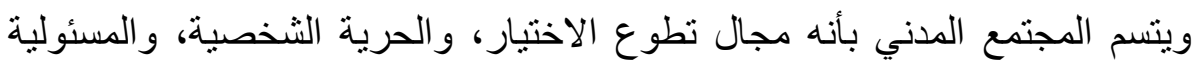

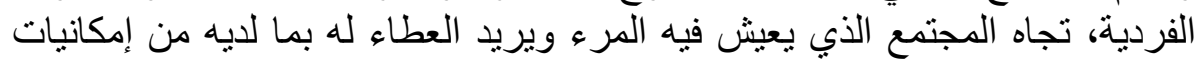

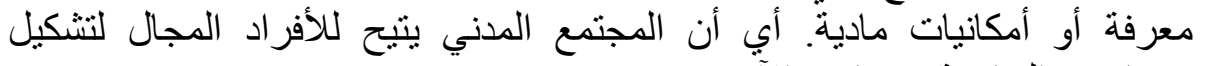
مصائر هم الخاصة ومساعدة الآخرين.

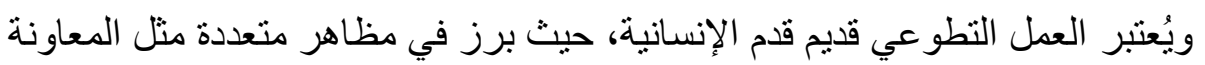

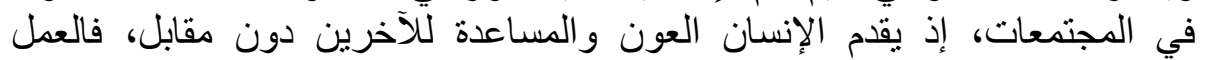

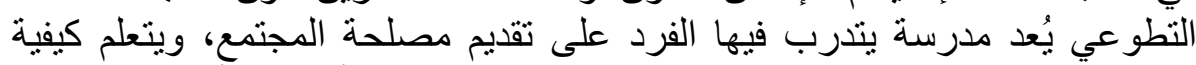

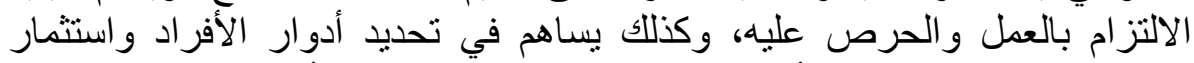

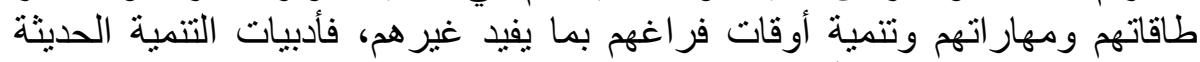

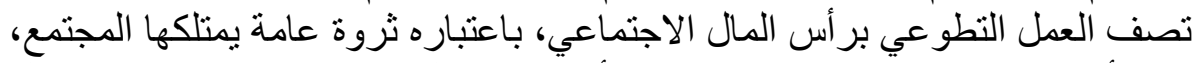

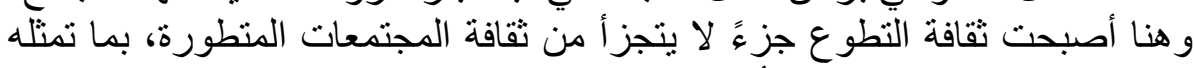

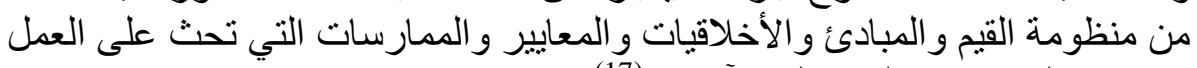
الإيجابي الذي يعود بالنفع على الآخرين الآلمين (17).

و هناك مسئولية كبيرة تقع على عائق مؤسسات المجتمع المدني، فيجب علئ عليهم

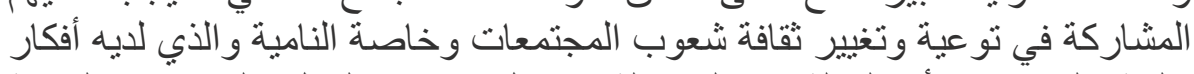

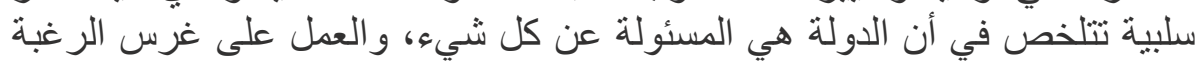


و الحماس في نفوس المواطنين للمشاركة في تحمل المسئولية تجاه وطنهم، و أنهم عليهم أن يكونوا إيجابيين.

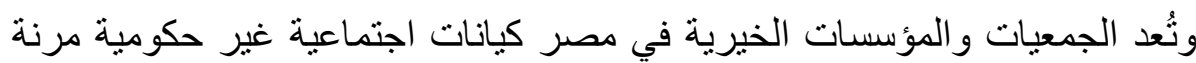

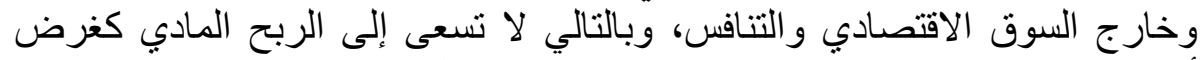

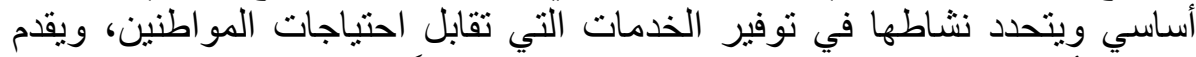

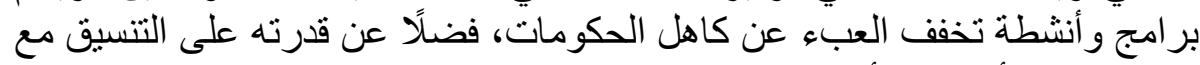

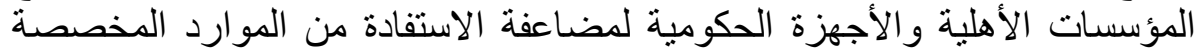
لتعزيز بر امج التنمية الاجتماعية.

ولقد حظيت هذه الكيانات الاجتماعية بدعم الدولة وتشجيعها ور عايتها، و أصبح للعمل

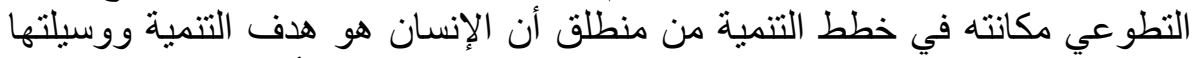

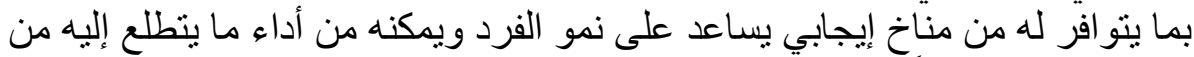

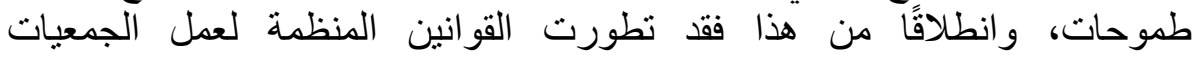

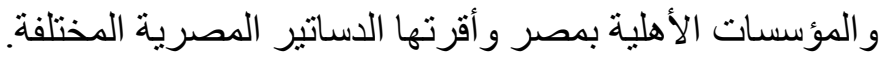

\section{المجتمع المدني والإعلام والحملات الإعلانية:}

وبالنظر إلى الواقع الفعلي في العديد من مؤسسات المجتمع المدني المشاركة في

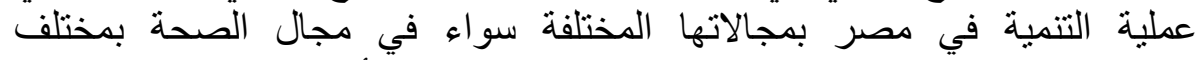

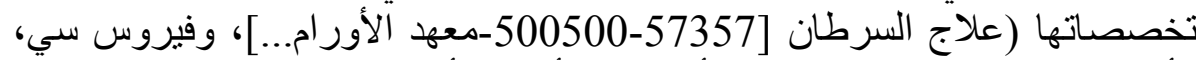

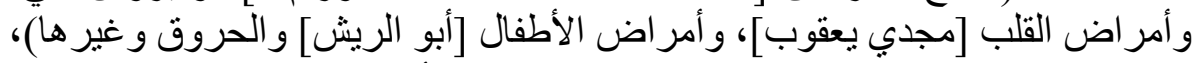

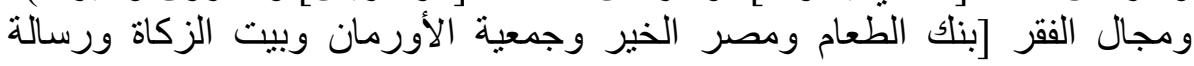

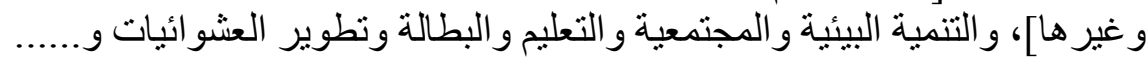

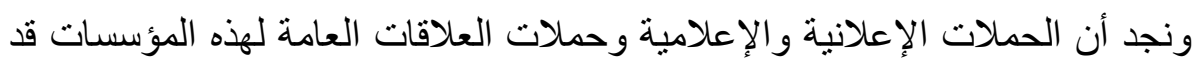

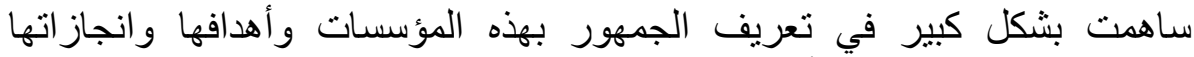

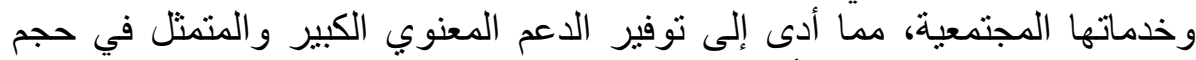

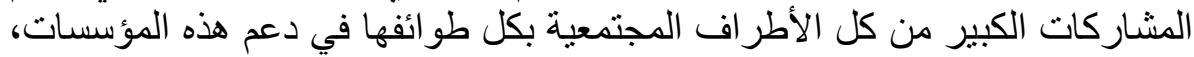

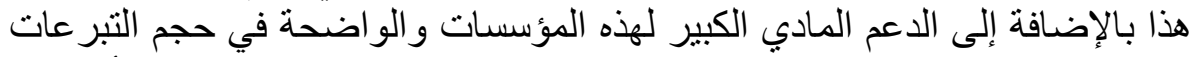
الكبيرة وبالتالي حجم الخدمات المقدمة من هذه المؤسسات وزيادة التهوة حجم أنشطتها و أفر عها وتطويرة وبالتي هجمال......

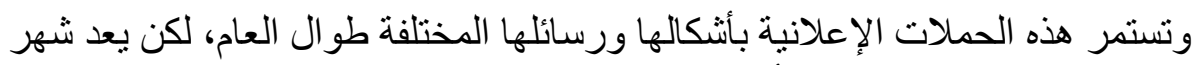

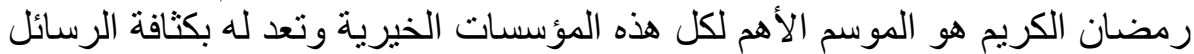

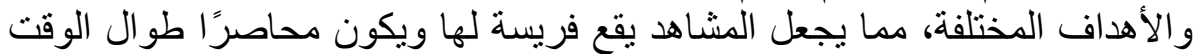

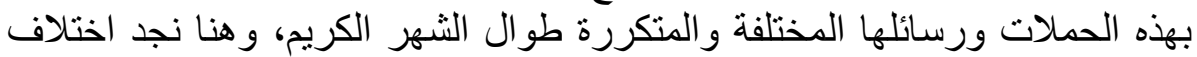

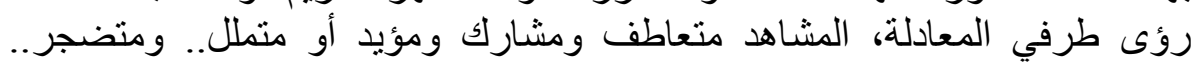


ور افض، والقائمون على المؤسسات يلهثون وراء التبرعات وسعداء بالعائد المادي

الضخم.

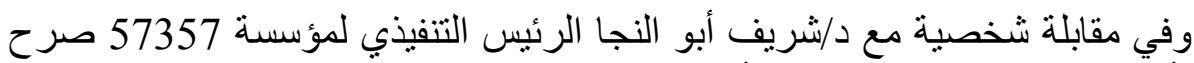

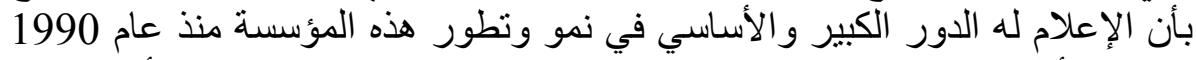

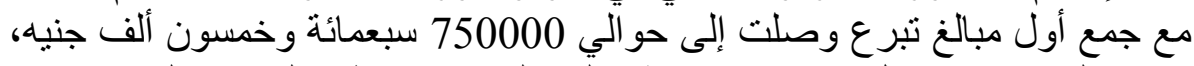

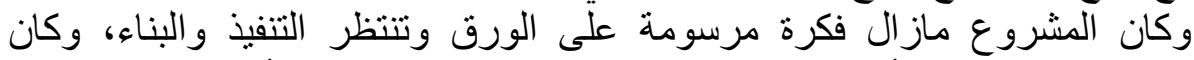

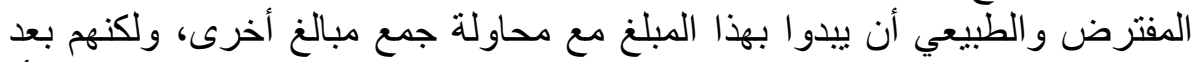

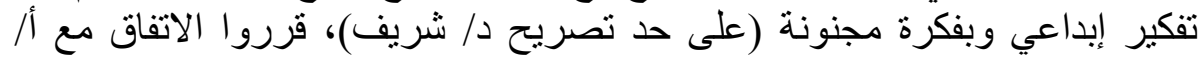

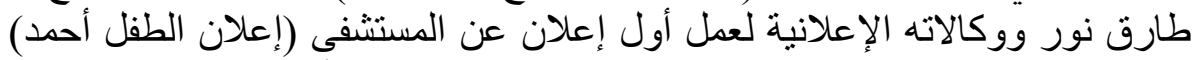

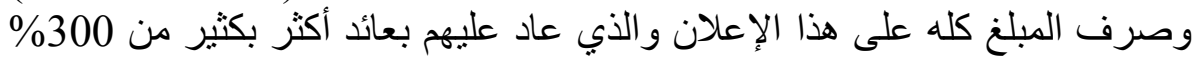

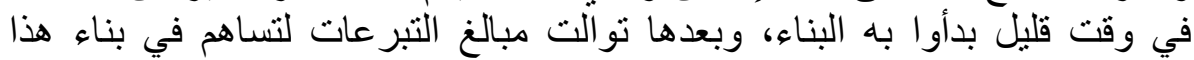
الصرح الطبي الكبير ونطويره.

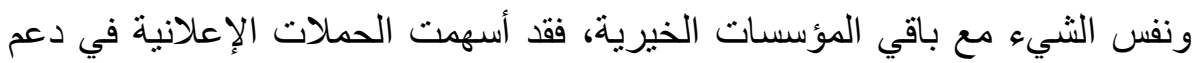

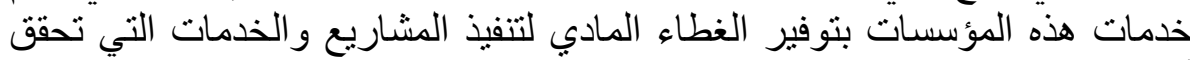

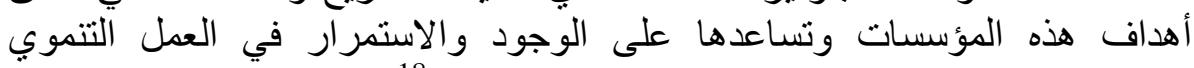

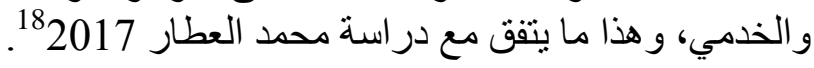

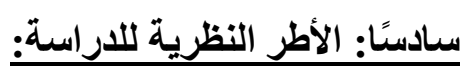

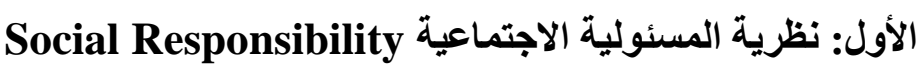

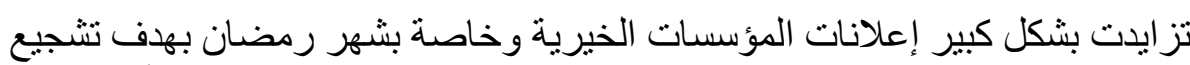

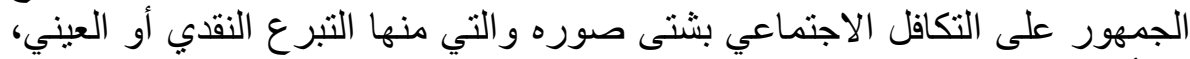

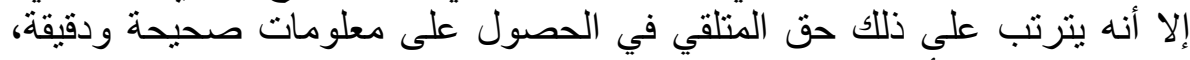

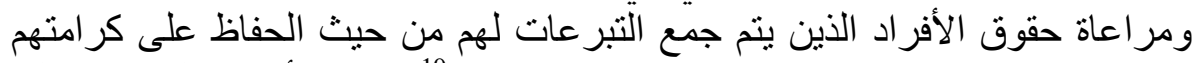

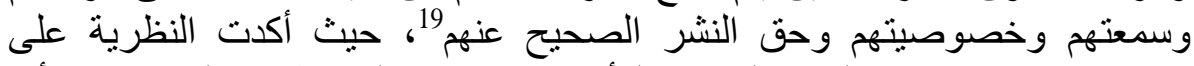

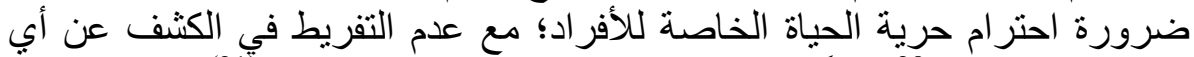

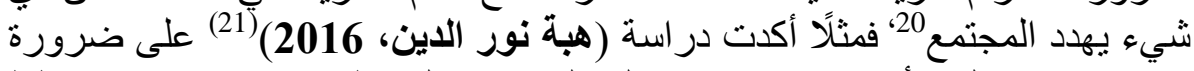

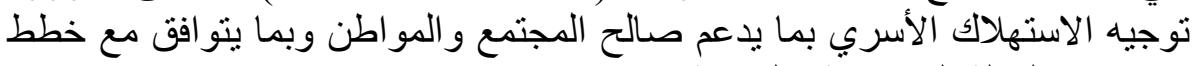
وسياسات الدولة التصنيعية والغذائية الائية.

لذا تنطلق الدراسة في إطار ها النظري من معطيات نظرية المسئولية الإسية الاجتماعية

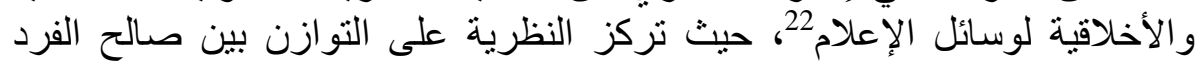

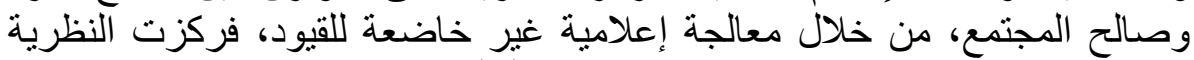

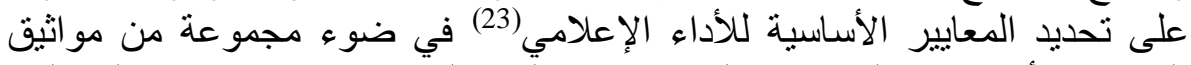

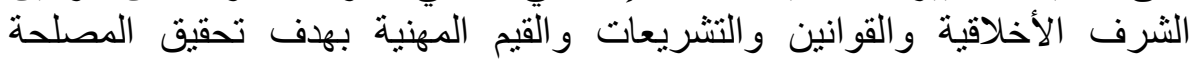




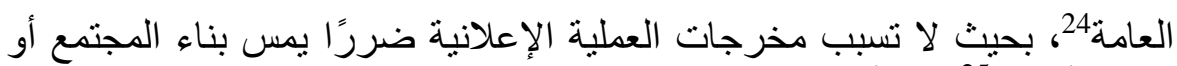

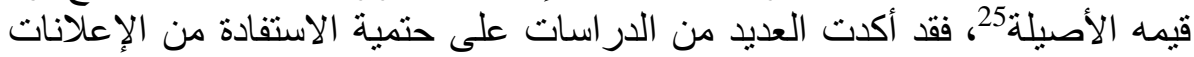

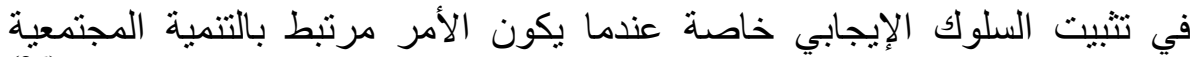

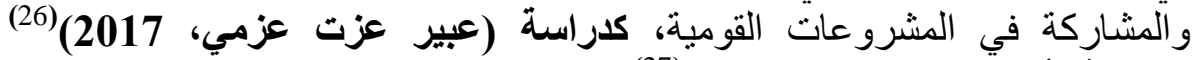
ودراسة (أحمد سيد حمودة، 2016) (27).

كما يؤكد ماكويل Mcqail على أن المبدأ الرئيسي لنظرية المسئولية الاجتماعية

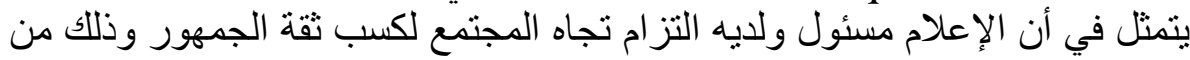

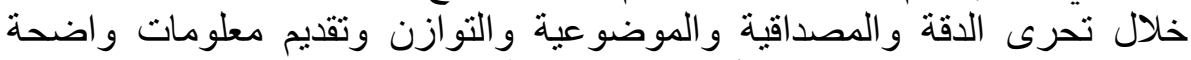

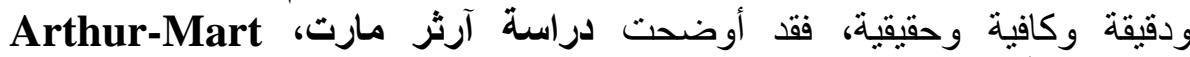

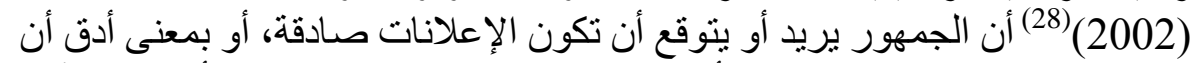

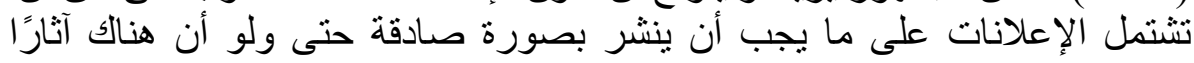

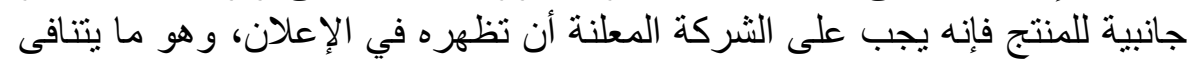

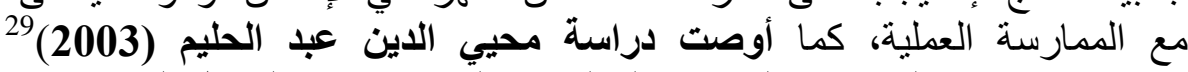

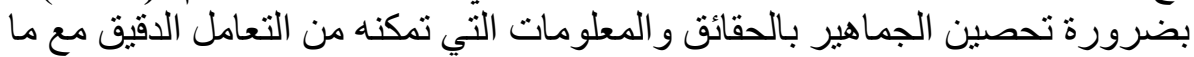
يتعرض لله إعلاميًا وهو الأمر الذي يتطلب تفعيل ميثاق العمل الصحفي والإعلاني الصئي وقو انين النشر.

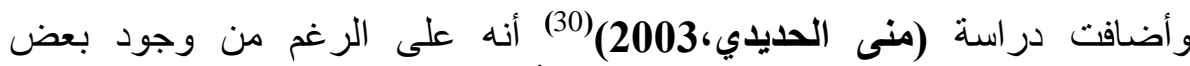

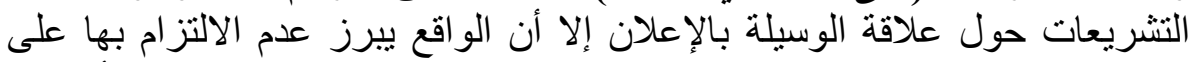

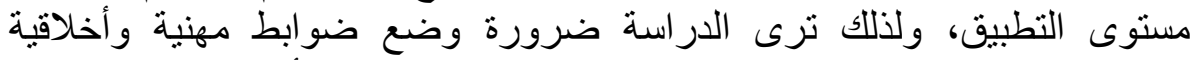
للإعلان الطبي و لا يترك إلا للمتخصصين، وفي وفي هذا الإطار أكدت دراسة استة (هويدا

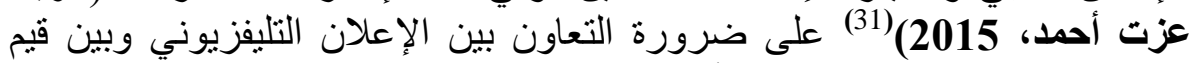

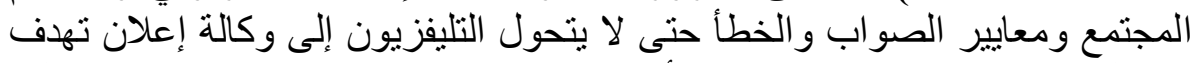

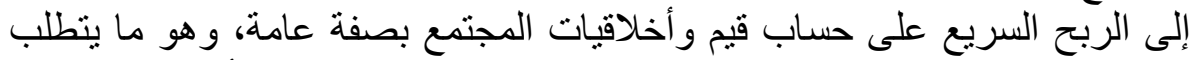
تحقيق مزيد من الفاعلية لآليات المراقبة وضبط الجية الجوانب الفنية والفية الأخلاقية للإعلان الذي يبث عبر القنوات التليفزيونية بما يحافظ على الفئ ثوابت المجتمع وقيمه.

و هنا في الدراسة الحالية تم قياس مدى مر اعاة إعلانات المؤسسات الخيرية للثفافية

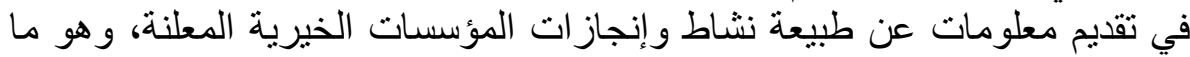

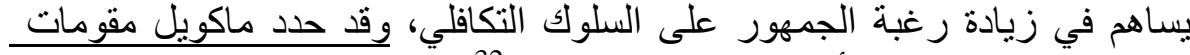

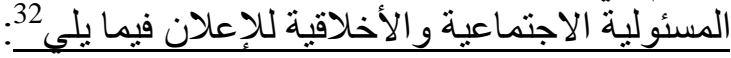

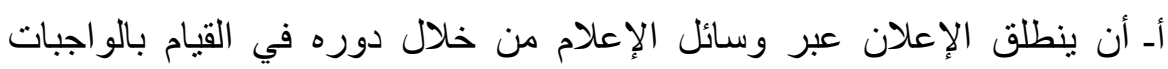
والالتز امات الاجتماعية. 


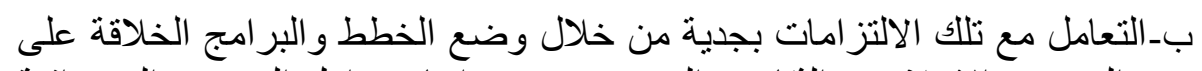

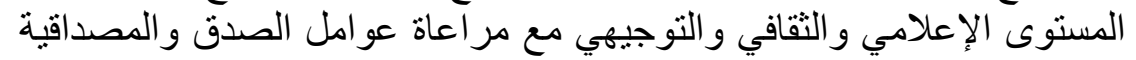

$$
\begin{aligned}
& \text { و الموضو عية في ضو الاعلادي وحددات التوافي التون الاجتماعي. } \\
& \text { جـ-أن يتم العمل في إطار من الإجر اءات و القو اعد التنظيمية. }
\end{aligned}
$$

دـأن يتم تجنب كل ما يضر المجتمع أو يسيء إليه من أفكار تعرقل نموه وتقدمهـ.

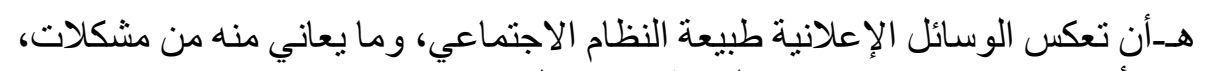

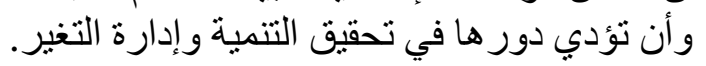

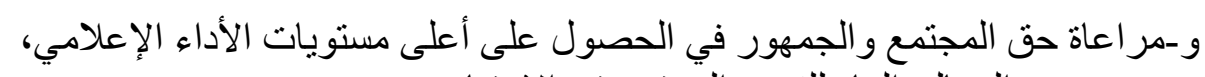

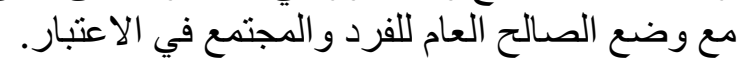

\section{الثاني: نموذج الفعالية الإعلانية لسامي عبد العزيز (33):}

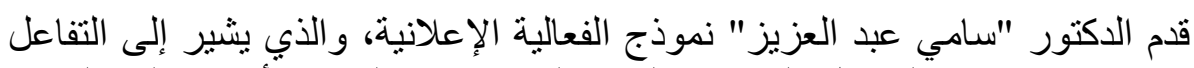

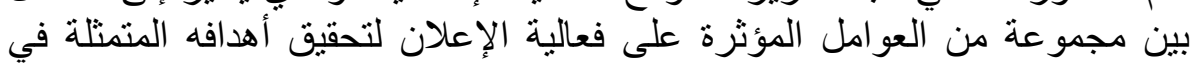

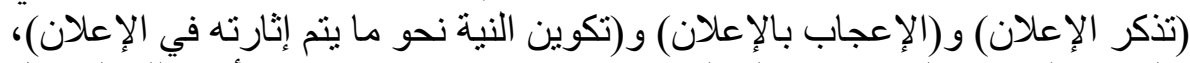

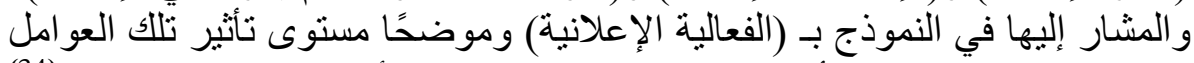

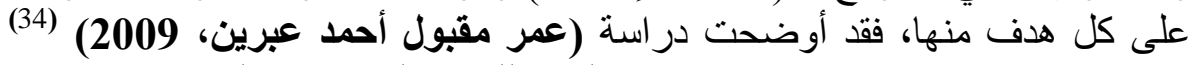

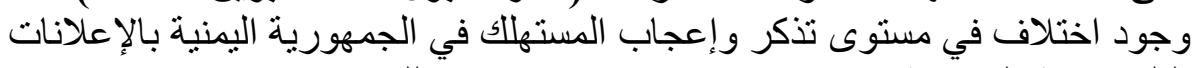

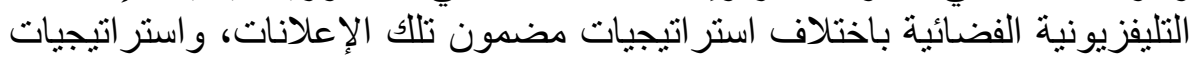

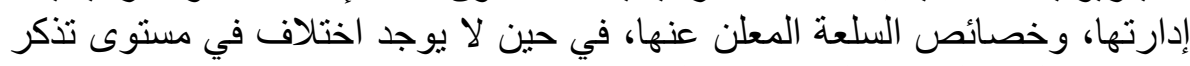

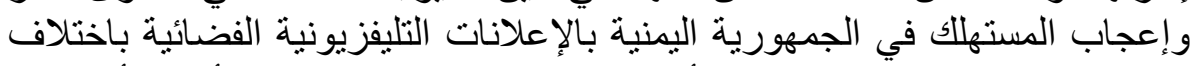

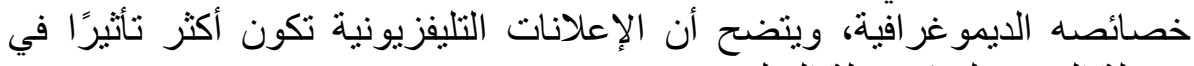
مرحلة الوعي تليها مرحلة الفعل. وتتمثل العوامل المؤثرة على فعالية الإعلان حسب مكونات النموذج في المحاور

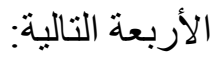

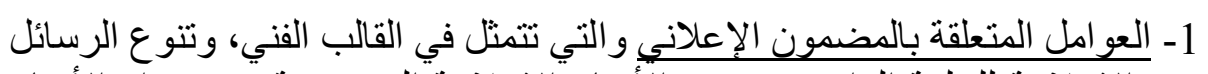

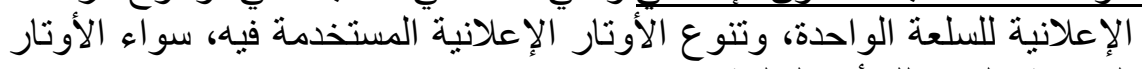
الخاصة بالمستهلك أو بالسلعة.

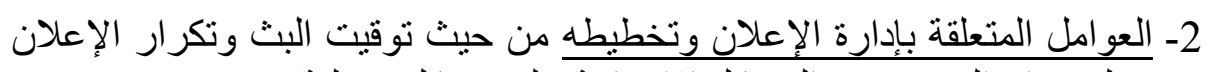

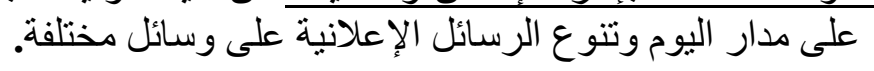

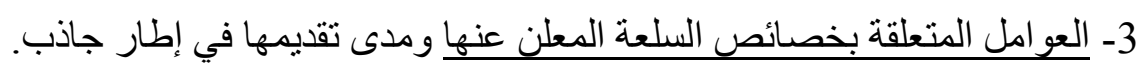


4- العو امل المتعلقة بخصائص الجمهور المتمثلة في السمات الديموجر افية الخاصة به الاهيه

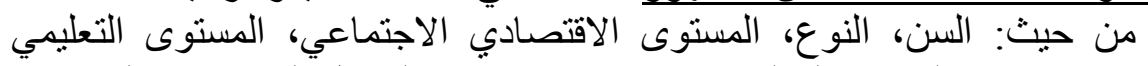

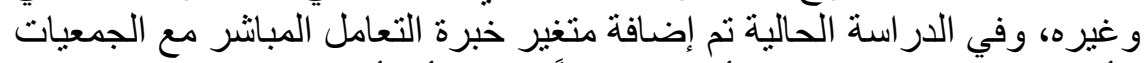

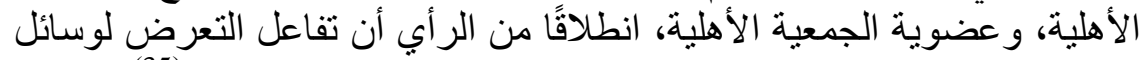

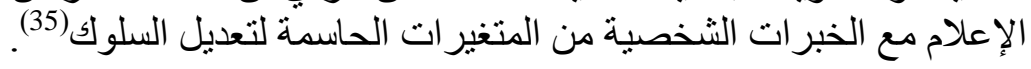

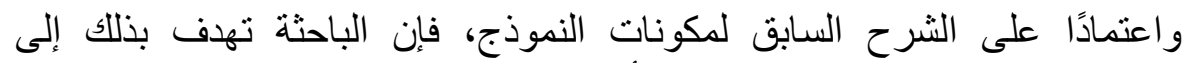

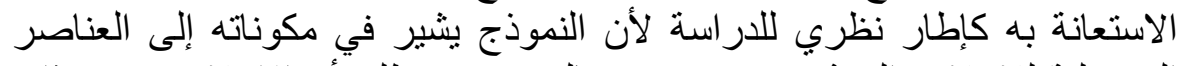

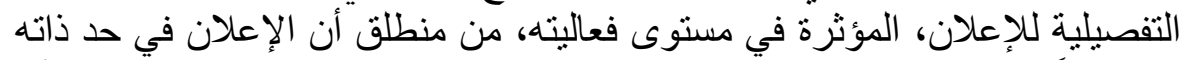

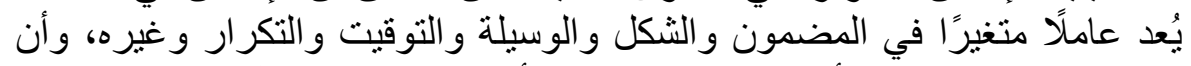

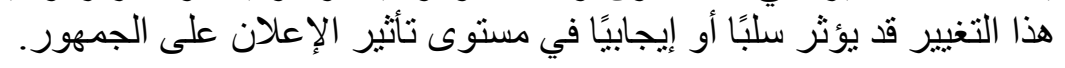

\section{أوجه الاستفادة من الأطر النظرية السابق ذكرها:}

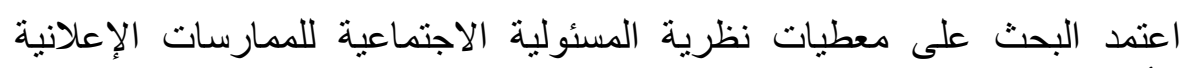

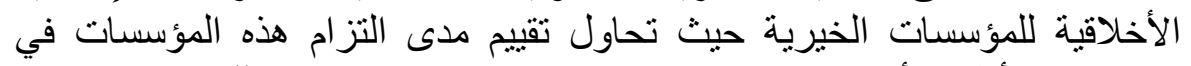

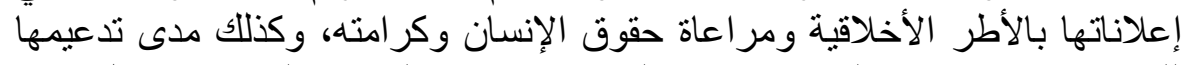

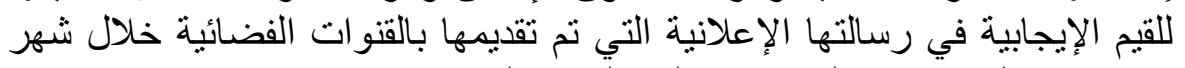
رمضان والتي تحث الجمهور على التبرع لهالئه حتى تتمكن من تقديم خدماتها للمتعاملين معها.

كما استندت الباحثة إلى عوامل نموذج فعالية الإعلان للاكتور سامي عبد العزيز

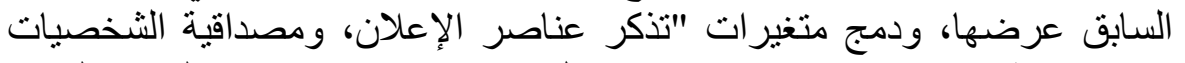

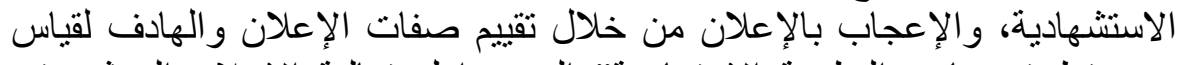

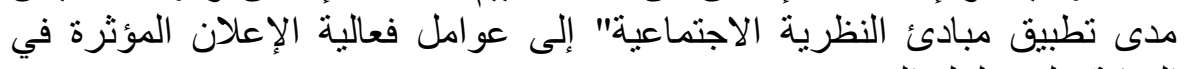

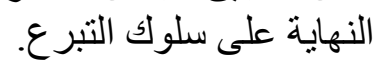

وسيتم لاحقًا تقديم نموذج مقترح لقياس تأثنر عوامل فعالية إعلانات المؤسسات

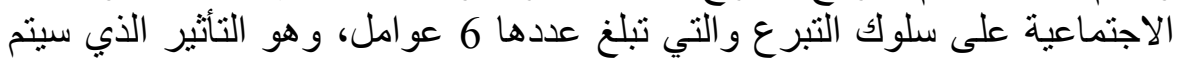

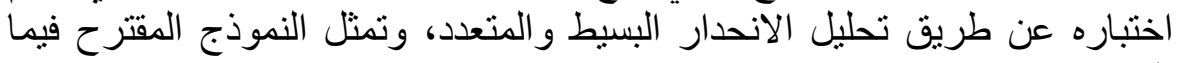
يلي: 


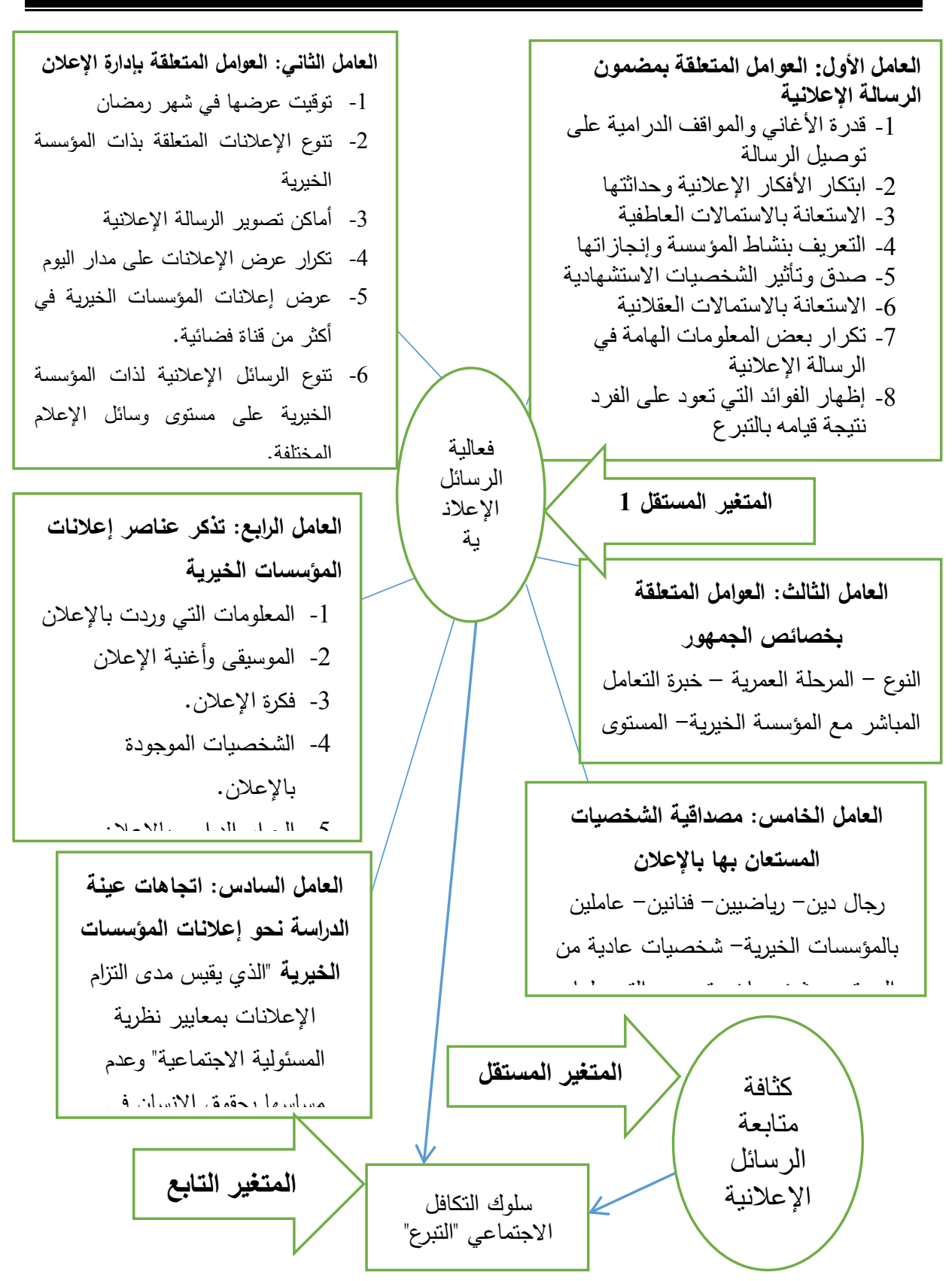

شكل رقم (1)

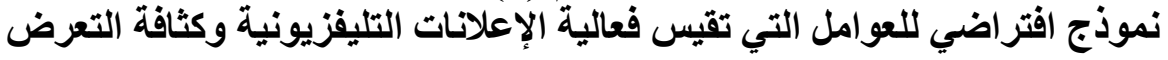

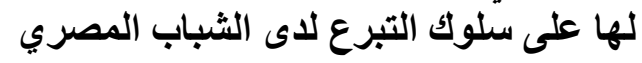




\section{سابعا: تساؤلات الار اسةة:}

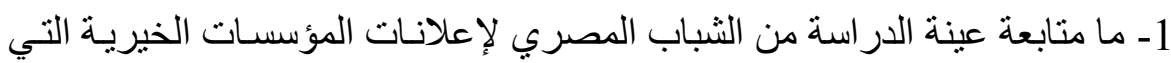

كانت تبث في القنوات الفضائية بشهر رمضنة النبان الكريم 2017؟

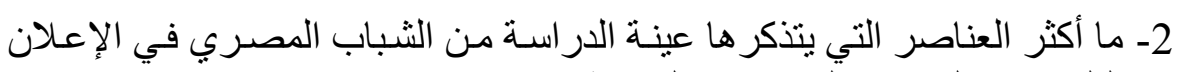

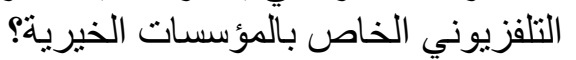

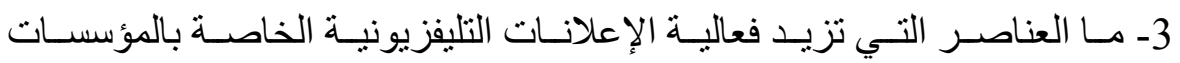

الخيرية؟

4- مـا مـدى مصــاقية الثخصـيات التـي يـتم الاسـتعانة بهـا بإعلانـات المؤسسـات

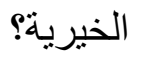

5- ما العوامل التي تؤثر في سلوك التكافل الاجتمـاعي بعد مشـاهدة الإعلانـات في

شهر رمضان؟

6- ما سلوك عينة الدر اسة الفعلي بعد مشاهدة إعلانات المؤسسـات الخيريـة في شـهر

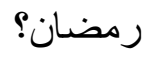

ثَامنًا: فروض الاراسة:

1- الفرض الرئيسي الأول: تؤوثر كثافـة متابعـة إعلانـات المؤسســات الخيريـة على

سلوك التبرع.

2- الفـرض الرئيسـي الثـاني: تـؤثر الفعاليـة الإعلانيـة على ســوك التبـر ع لعينـة

الدراسة.

وينبتق من هذا الفرض الرئيسي مجمو عة من الفروض الفرعية على النحو التالي:

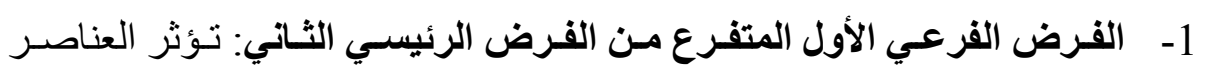

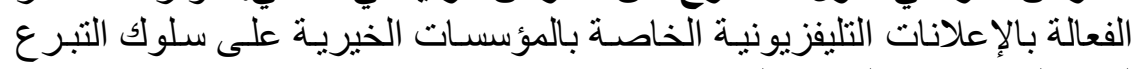

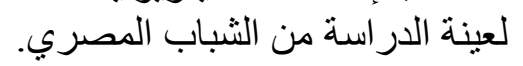

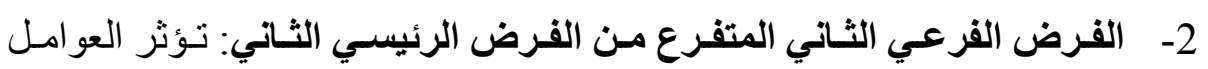

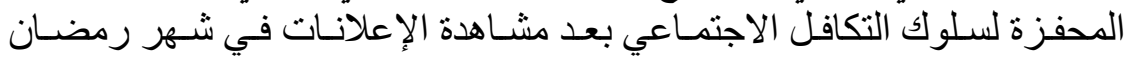
الكريم على سلوك التبر ع لعينة الدر أسة من الثباب الثعل المصري.

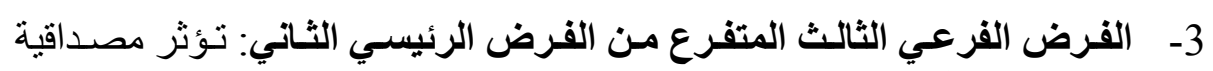

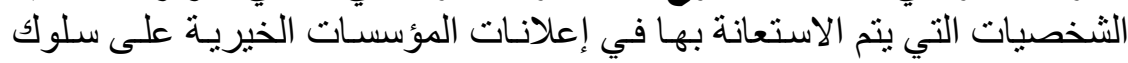
التبر ع لعينة الدراسة من الثباب المصري. 
4- الفرض الفرعي الرابـع المتفرع مـن الفـرض الرئيسي الثـاني: تـؤثر العوامـل

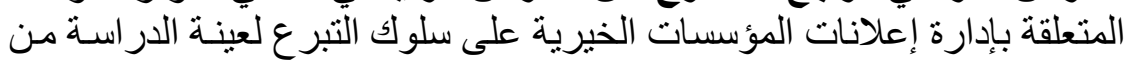

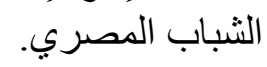

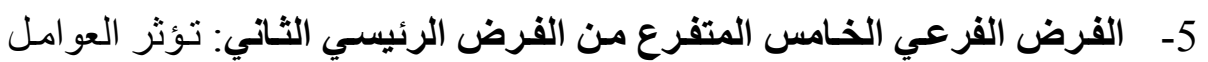

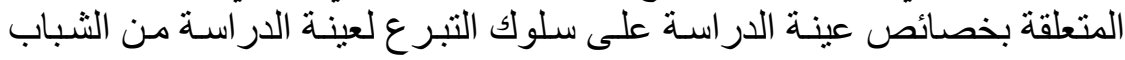

$$
\text { المصري. }
$$

6- الفرض الفرعي السـادس المتفرع من الفرض الرئيسي الثاني: تـؤثر اتجاهـات

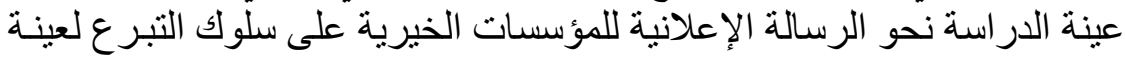

$$
\text { الدر اسة من الثباب المصرئ الرساب. }
$$

\section{تاسعنًا: الإجراءات المنهجية للار اسة:}

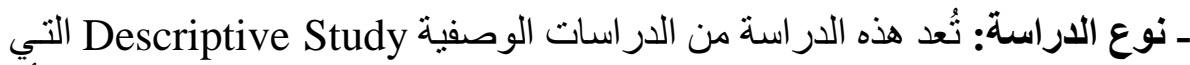

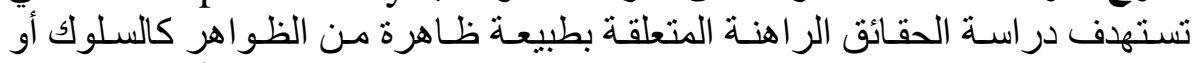

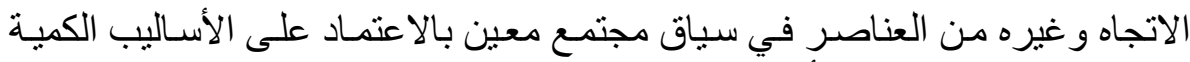

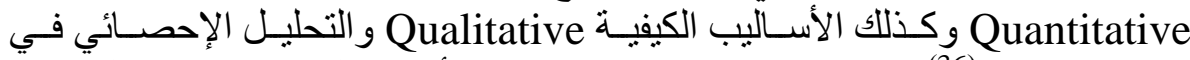

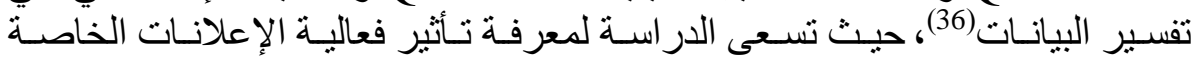

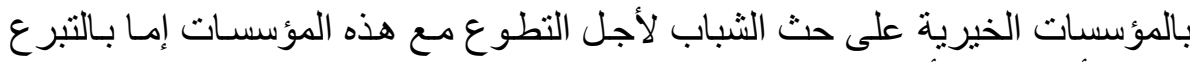

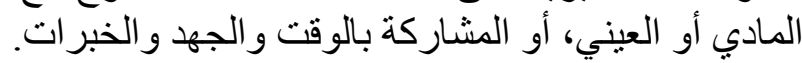

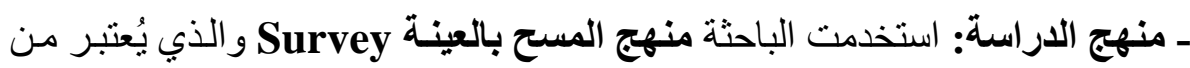

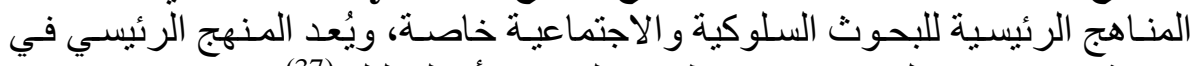

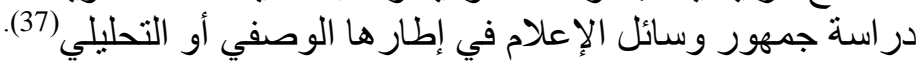
ـ مجتمع وعينة الار اسةة الميدانية:

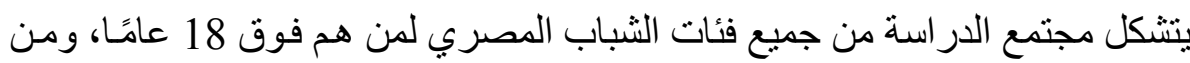

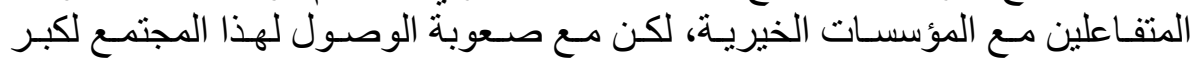

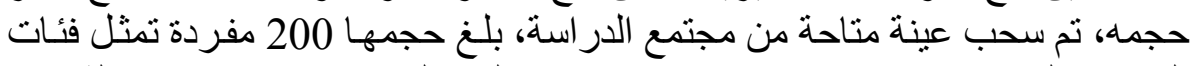

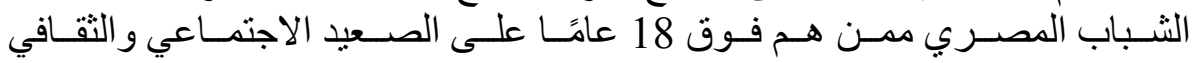

$$
\text { والاقتصادي و النوعي. }
$$

ألتالي: عن خصائص عينة الدر اسة الميدانية الديموجر افية و التعليمية، فكانت على النحو 


\section{جدول رقم (1) خصائص عينة الدراسة الميدانية الديموجرافية والتعليمية}

\begin{tabular}{|c|c|c|c|}
\hline النسبة & التكرار & 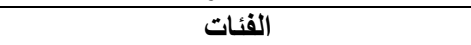 & المتغيرات - ات \\
\hline 50.5 & 101 & ذكر & \multirow[t]{2}{*}{ النوع } \\
\hline 49.5 & 99 & أنثىى & \\
\hline 29.5 & 59 & من 18 سنة إلى أقل من 25 سنة & \multirow[t]{3}{*}{ السن } \\
\hline 50.5 & 101 & من 25 سنة إلى أقل من 35 سنة & \\
\hline 20 & 40 & من 35 سنة إلى أقل من 45 سنة & \\
\hline 37.5 & 75 & مؤهل متوسط أو فوق المتوسط & \multirow[t]{3}{*}{ المستوى التعليمي } \\
\hline 58.5 & 117 & مؤ هل جامعي & \\
\hline 4 & 8 & در اسات علبا (دبلوم/ ماجستير أو دكتوراة) & \\
\hline 54 & 108 & نعم & \multirow{2}{*}{ عضوية جمعية } \\
\hline 46 & 92 & $\mathrm{y}$ & \\
\hline
\end{tabular}

يكثف الجدول السابق عن خصائص عينة الاراسة الايموجرافية والتعليمية كما

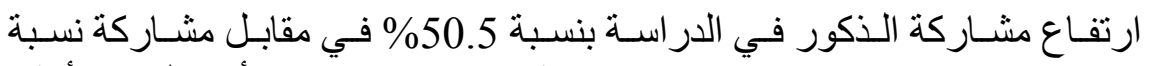
49.5\% من الإناث و هو ما يتفق مع در اسـة محمد رمضـان فئان في أن و الذكور أكثر

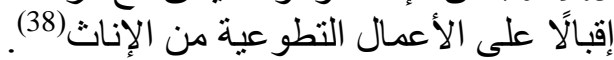

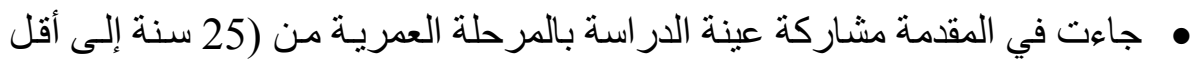

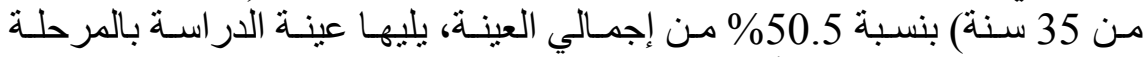

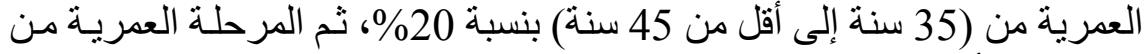

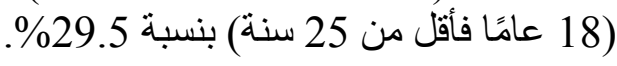

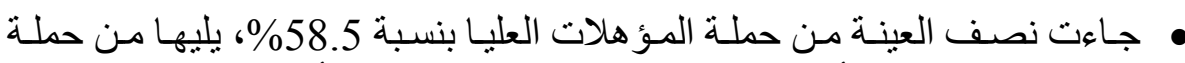

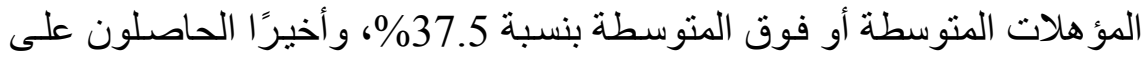

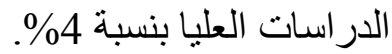

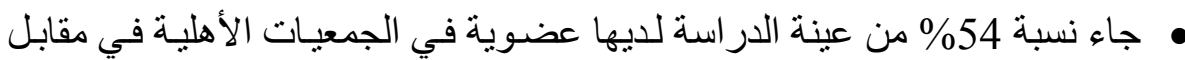

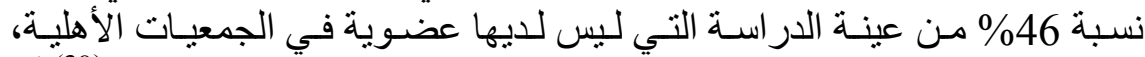

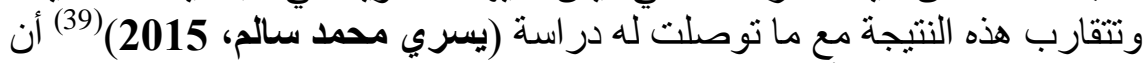

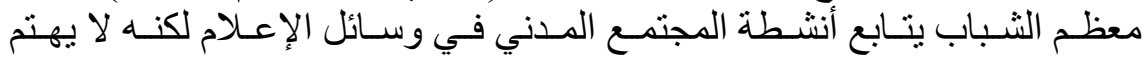
بالانضمام لها حيث ظهر ذلك بنسبة 57.4 \% • و فيمـا يتعلق بخصـائص عينـة الدر اسـة الميدانيـة الاقتصـادية، فكانـت على النحو التالي: 
جدول رقم (2) خصائص عينة الدراسة الميدانية الاقتصادية

\begin{tabular}{|c|c|c|c|}
\hline النسبة & التكرار & الفئات & المتغيرات - - مات \\
\hline 13.5 & 27 & أقلّ من ألف جنيه & \multirow[t]{4}{*}{ الدخل الثهري } \\
\hline 51.5 & 103 & من ألف جنيه إلى أقل من ثلاث آلاف جنيه & \\
\hline 30.5 & 61 & من ثلاث آلاف جنيه إلى أقل من خمسة آلاف جنيه & \\
\hline 4.5 & 9 & خمسة آلاف فأكثر & \\
\hline 52.5 & 105 & تمليك & \multirow[t]{2}{*}{ 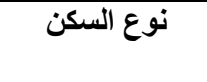 } \\
\hline 47.5 & 95 & إيجار & \\
\hline 80.5 & 161 & $\bar{y}$ & \multirow{2}{*}{ السفر خارج مصر } \\
\hline 19.5 & 39 & نعم & \\
\hline 13.5 & 27 & نعم & \multirow{2}{*}{ عضوية نادي } \\
\hline 86.5 & 173 & $\bar{y}$ & \\
\hline 41 & 82 & نعم & \multirow[t]{2}{*}{ امتلاك سيارة } \\
\hline 59 & 118 & $\bar{y}$ & \\
\hline 22 & 44 & Ios & \multirow{3}{*}{ نوع الهماتف } \\
\hline 77 & 154 & اندرويد & \\
\hline 1 & 2 & محمول عادي & \\
\hline \multicolumn{2}{|c|}{200} & \multicolumn{2}{|l|}{ الإجمالي } \\
\hline
\end{tabular}

يكشف الجدول السابق عن الخصائص التالية:

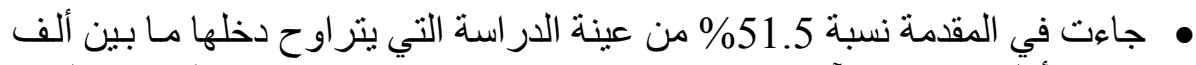

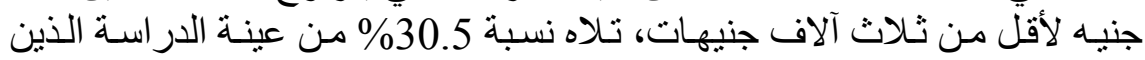

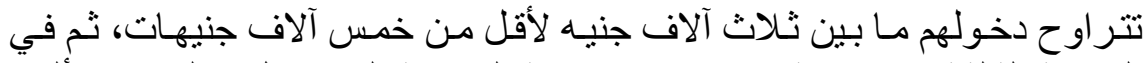

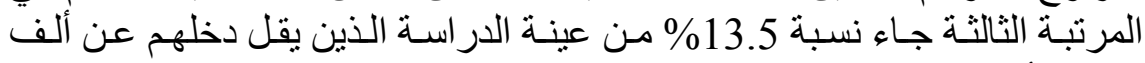

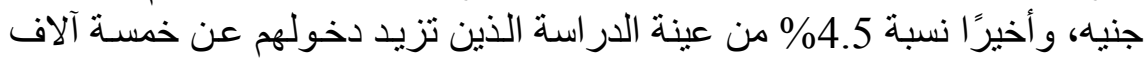
جنيهًا فأكثر.

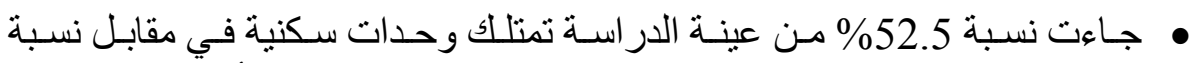

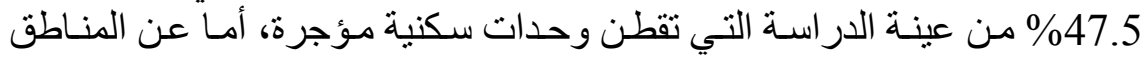

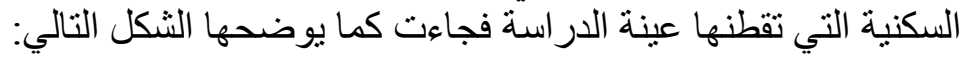

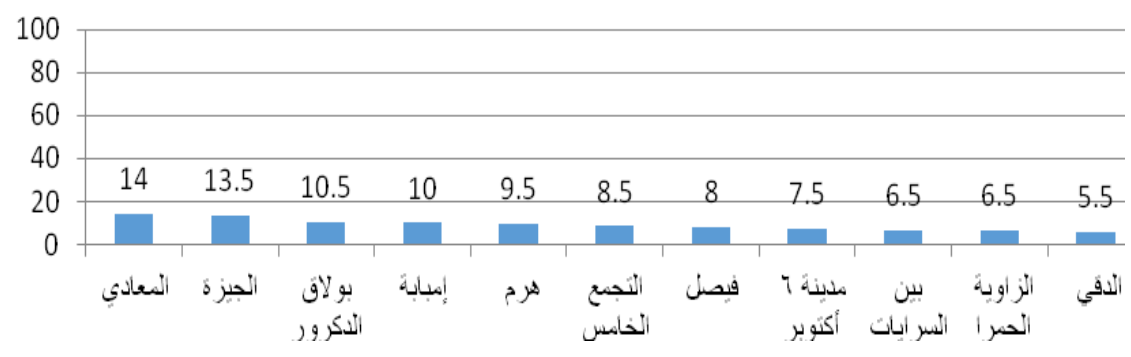


شكل رقم (2) المناطق السكنية التي تقطنها عينة الدراسة الميدانية

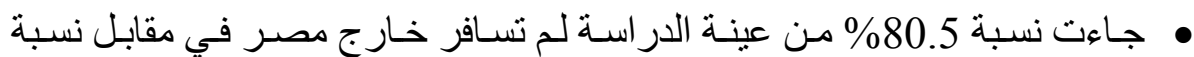

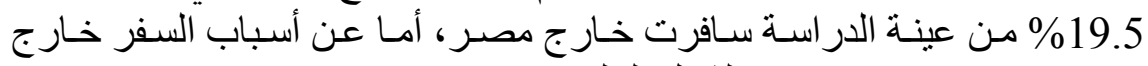
مصر، فجاءت كما يوضحها الثكل التالي:

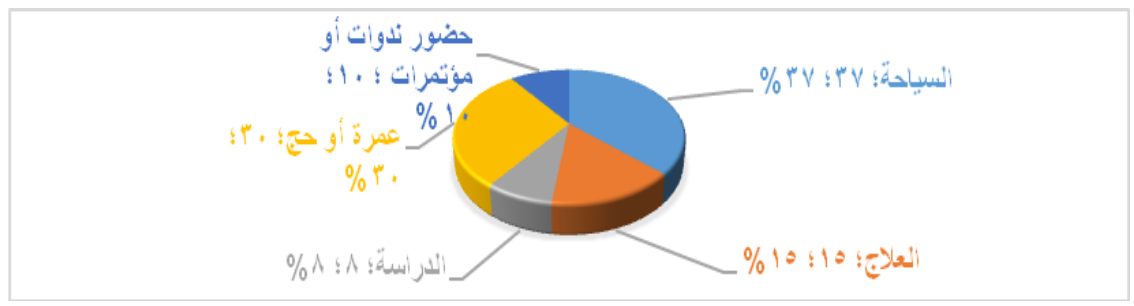

\section{شكل رقم (3) أسباب سفر عينة الدراسة الميدانية خارج مصر}

هاءت نسبة 86.5\% من عينة الدر اسة لا تمنلك عضوية نـادي رياضي في في مقابل

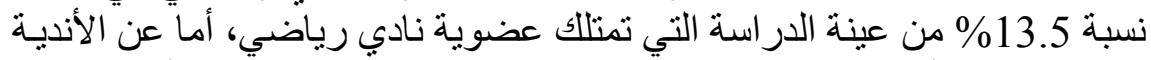

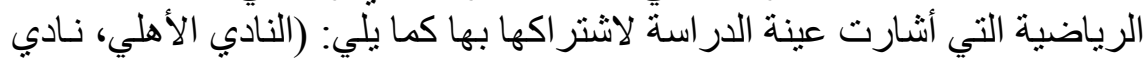

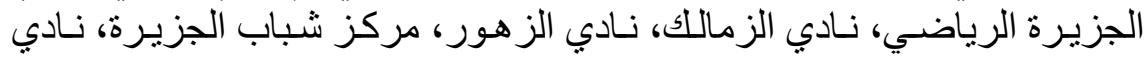

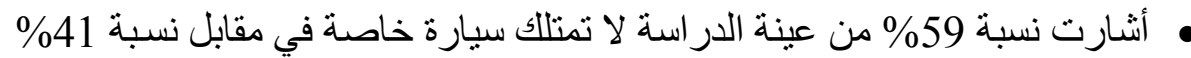

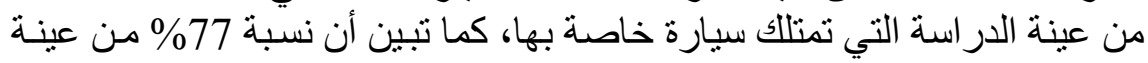

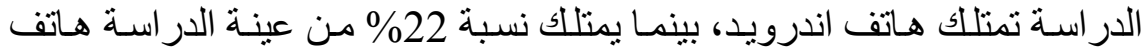
iOS في مقابل نسبة 1\% 1 نمتلك هاتف محمول عادي. ويستخلص من إجابات عينة الدراسة على العناصر التي تقيس المستوى الاقتصادي

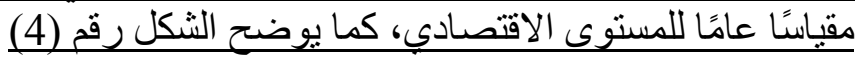

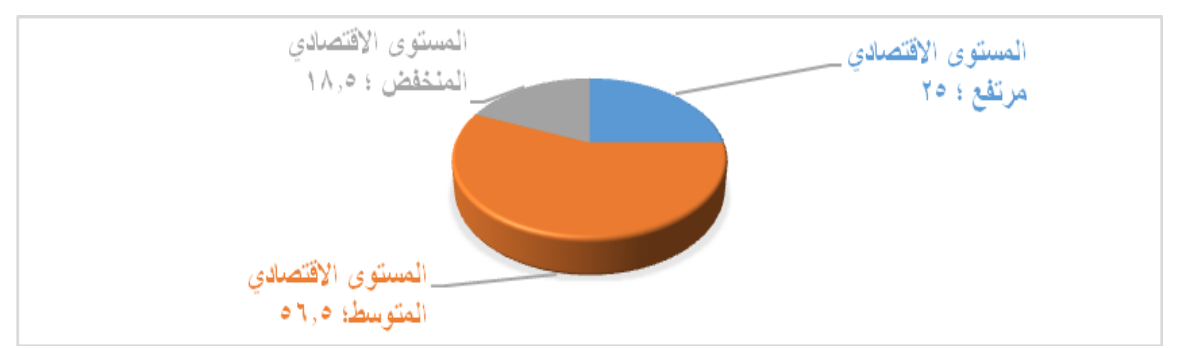

يكثنف الثكل السابق عن المستويات الاقتصادية لعينة الدر اسة، حيث جاء في المقدمـة

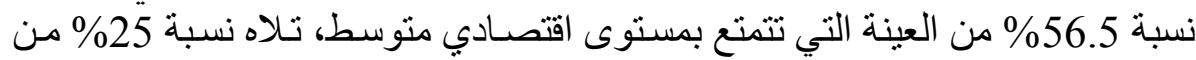


العينـة التي تتمتـع بمستوى اقتصـادي مرتفـع، و أخيرًا جـاء نسـبة 18.5\% مـن عينـة

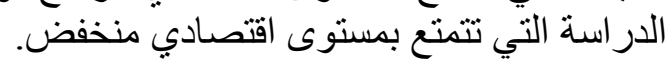

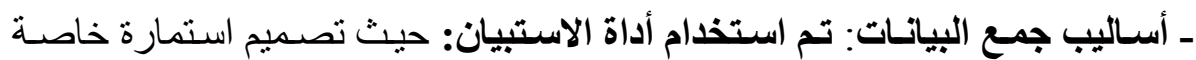

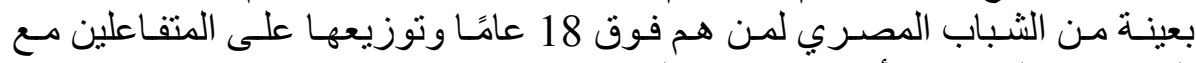
المؤسسات الخيرية وتأثثير إعلاناتها عليهم.

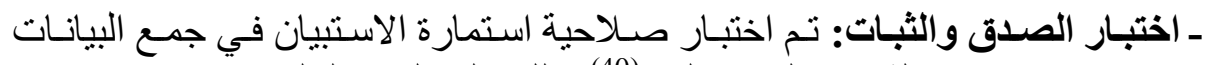

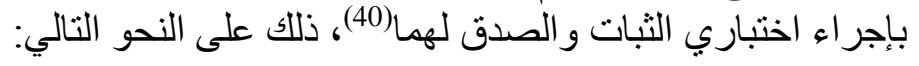

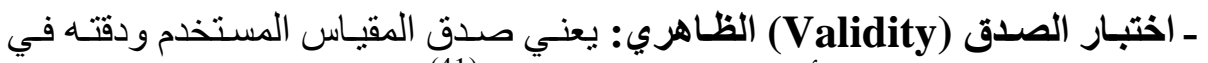

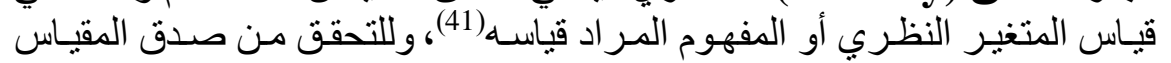

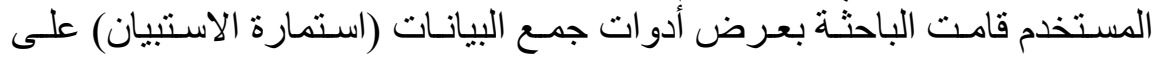
مجمو عة من الخبر اء و المتخصصين في مناهج البحثث والت الإعلام و الإحصاء

ـ اختبار الثبات (Reliability): قامت الباحثة بنطبيق اختبار الثبات على عينة تمثل

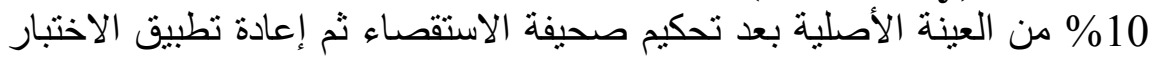
مرة ثانية على عينة 5\% من الأبنة المبحوثين بعد أسبو عين من الاختبار الأول، للتأكد

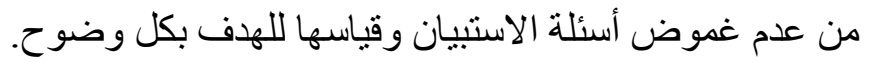

\section{عاثرًا: التحليل الإحصائى للبيانات(42)}

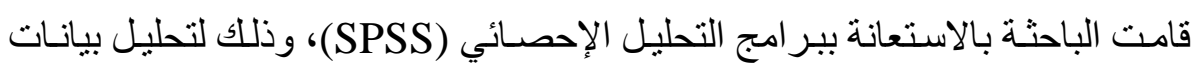

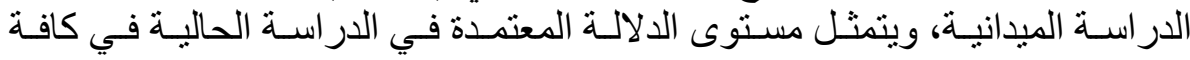

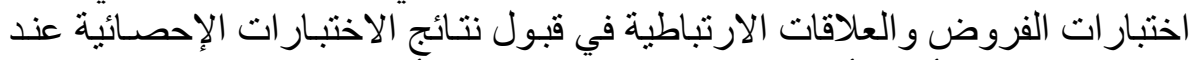
درجة تقة 95\% فأكثر ، أي عند مستوى معنوية 0.05 فأقَّل.

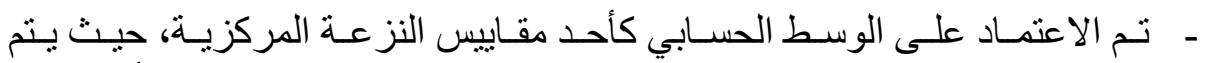
الاعتماد عليه في تكوين مقياس بسيط (يعتمد في تكوينه على متغير واحد) أو مقياس الونس

\begin{tabular}{|c|c|}
\hline & \\
\hline & \\
\hline & \\
\hline & \\
\hline & \\
\hline & \\
\hline & \\
\hline & \\
\hline & \\
\hline & \\
\hline & \\
\hline استقصاء الر أي الميدانية: المية: & • المحكمون لصحيفة \\
\hline عميد كلية الإععلام و العلاقات العام -جامعة النهضة سابقا & 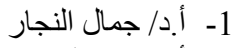 \\
\hline المفكر وعالم المصريات & 2- ا.د/وسيم السيسي \\
\hline المشرف على قسم الصحافة ـكلية الإعلام_الجامعة الحديثة للتكنولوجيا و المعلوه & 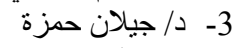 \\
\hline مدرس العلاقات العامة كلية الإعلام_الجامعة الحديثة للتكنولوجيا و المعلومات & 4- عبد التواب مصطفى \\
\hline مدرس إذاعة وتليفزيون ـكلية الإعلام-الجامعة الحديثة للتكنولوجيا و المعلومات & 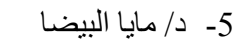 \\
\hline مدرس إذاعة وتليفزيون ـكلية الإعلام_الجامعة الحديثة للتكنولوجيا و المعلومات & 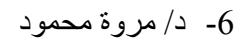 \\
\hline مدرس العلاقات العامة ـكلية الإعلام_الجامعة الحديثة للتكنولوجيا و المعلومات & 7- د/و لاء يحيى \\
\hline مدرس العلاقات العامة ـكلية الإعلام_الجامعة الحديثة للتكنولوجيا و المعلومات & 8- د/مي محفوظ \\
\hline 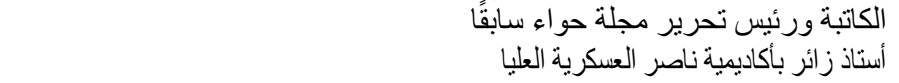 & 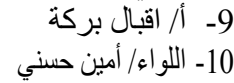 \\
\hline
\end{tabular}




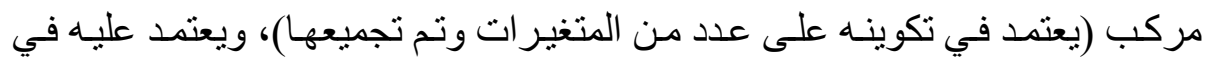

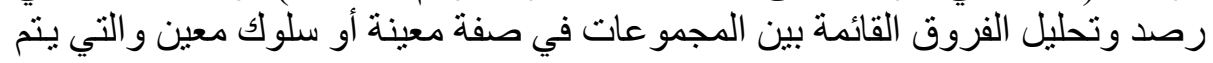

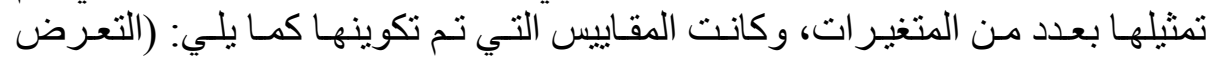

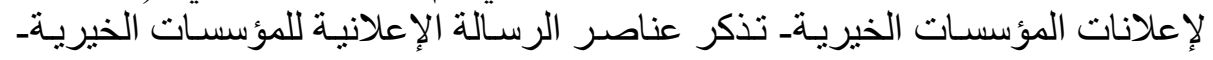

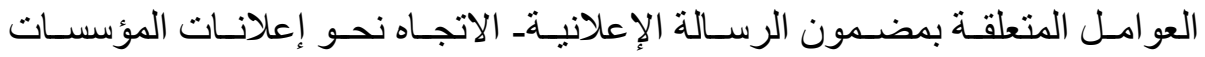

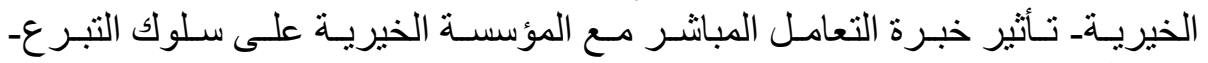

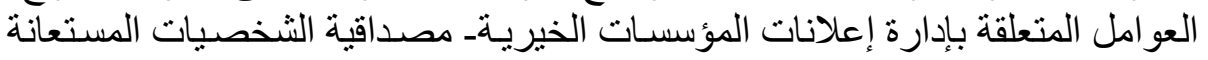

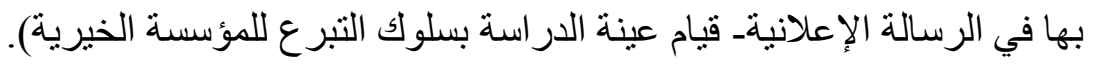

- تم استخدام معامل الارتباط بيرسون (Pearson correlation coefficient)

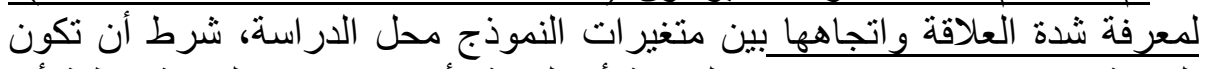

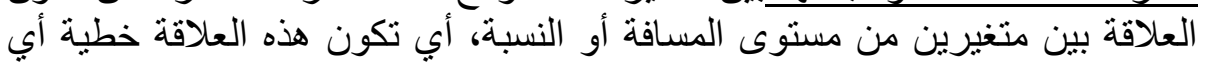
بمكن تمثيلها بخط مستقيم يصف من منير العلاقة في جانبين منها. ويعبر قيمة معامل الارتباط عن الفئات الثثلاثة التالية:

• كانت القيمة أقل من (+3،-3) يعني قوة ارتباط منخفضة للغاية.

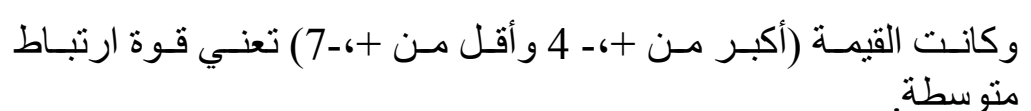

وكانت القيمة الأكبر من (-6+7 حتي 1) تعني قوة ارتباط عالية وقوية.

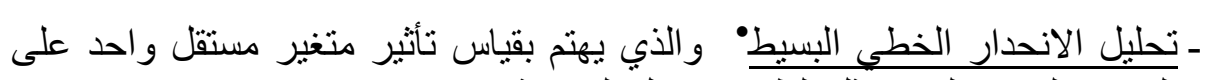
المتغير التابع والذي يمثل الظاهرة البطة محل الدراسة.

- تحليل الانحدار المتعدد المعياري حيث يتم إدخال جميع المتغير ات المستقلة في

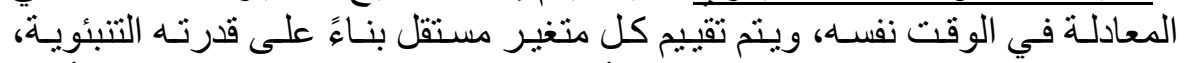

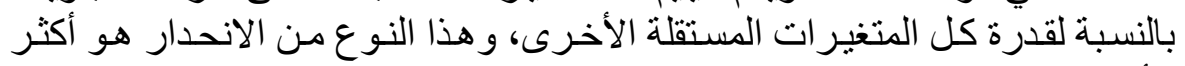

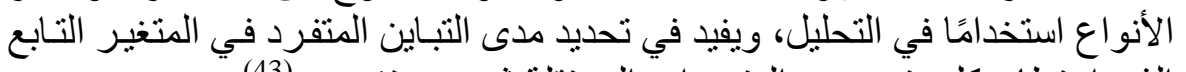

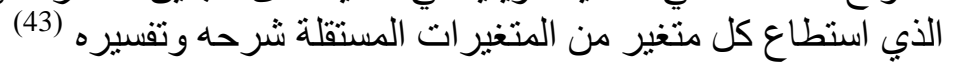

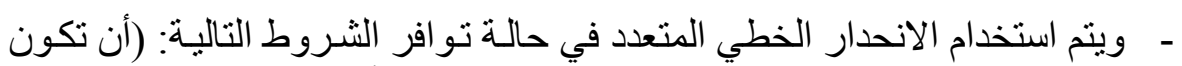

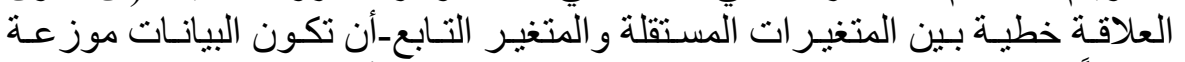

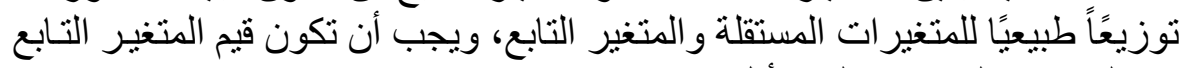
من المستوى الترتيبي على الأقل).

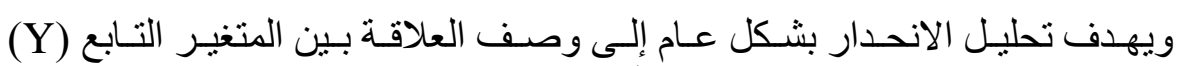

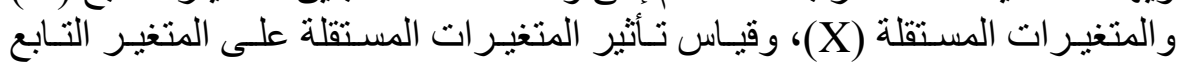


ومعرفة مدى أهمية هذا التأثثر، كما بسـاعد تحليل الانحدار على التنبؤ بقيم المتغير

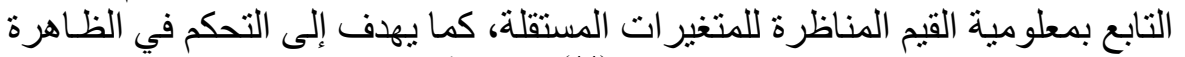

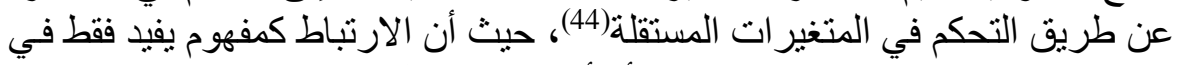

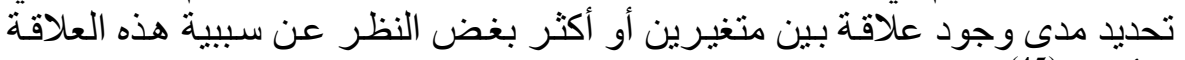
ونأثير هاب(45).

أحد عشرًا: نتائج الدراسة الميإنية: الجزء الأول: التساؤلات العامة للاراسة التابلة الميدانية: المحوها: الأول: اهتمام عينة الاراسة بإعلانات المؤسسات الخيرية واتجاهاته • شكل رقم (5) متابعة عينة الدراسة لإعلانات المؤسسات الخيرية التي كاتت تبث في القنوات الفضائية بشهر رمضابعة عينة الكران الكريم 2017:

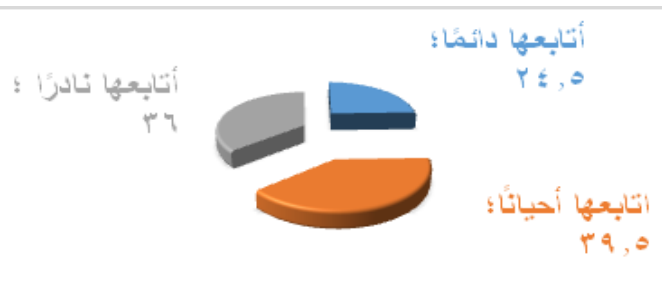

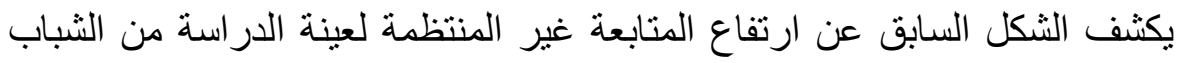

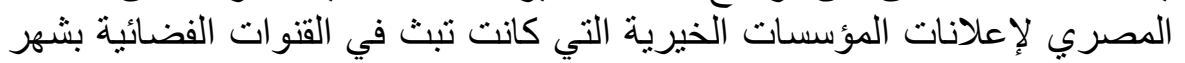

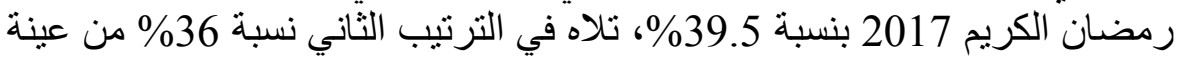

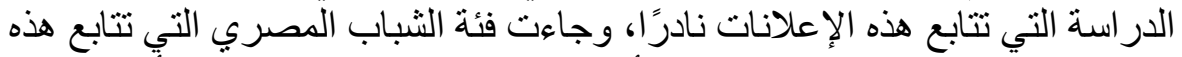

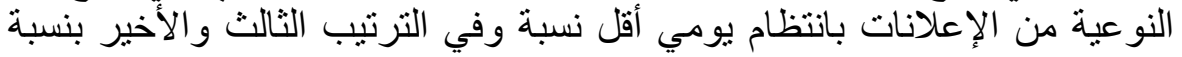

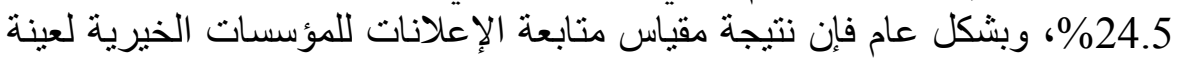

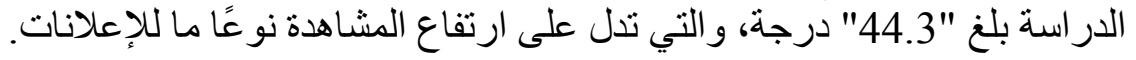

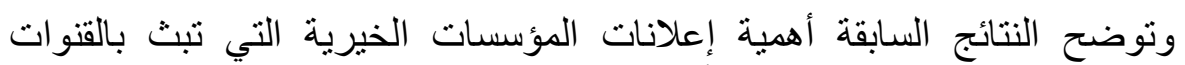

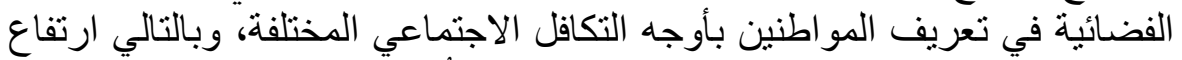

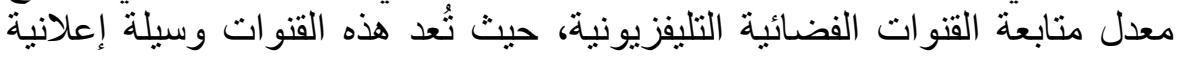

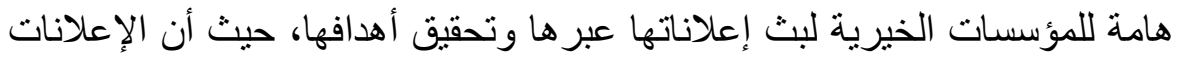

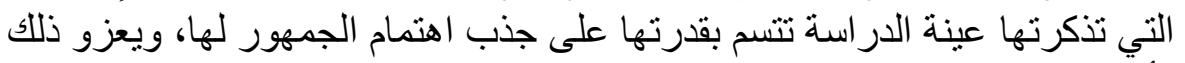
لأنها تعزز قيم إيجابية و هي التكافل و التر ابط و التدين. 
أما عن أسماء أكثر الإعلانات التليفزيونية التي تتذكرها عينة الدراسة، فجاعت كما

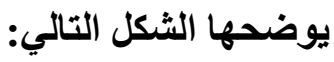
جدول رقم (3) أكثر إعلانات المؤسسات الخيرية التي تتذكرها عينة الدراسة من

\begin{tabular}{|c|c|c|c|}
\hline الترتيب & النسبة & تكرار التذكر & أسماء الإعلانات \\
\hline 1 & 20.4 & 78 & مستشفى 57357 \\
\hline 2 & 17.8 & 68 & مستشفى مجدي يعقوب \\
\hline 3 & 12 & 46 & جمعية رسالة الخيرية \\
\hline 4 & 11.3 & 43 & مستشفى 500500 \\
\hline 5 & 10 & 38 & جمعية الأورمان \\
\hline 5 & 10 & 38 & مؤسسة مصر الخير \\
\hline 6 & 6.5 & 25 & مؤسسة بهية \\
\hline 7 & 3.7 & 14 & مستشفى الحروق \\
\hline 8 & 3.4 & 13 & مستشفى الكبد \\
\hline 9 & 1.6 & 6 & المعهد القومي للأورام \\
\hline 9 & 1.6 & 6 & بيت الزكاة المصري \\
\hline 10 & 1 & 4 & مستشفى أبو الريش \\
\hline \multirow[t]{2}{*}{11} & 0.7 & 3 & مؤسسة بنك الطعام \\
\hline & 100 & 382 & الإجمالي \\
\hline
\end{tabular}

يوضح الجدول السابق ترتيب الإعلانات الخاصة بالمؤسسات الخيرية ومدى تذكر ها

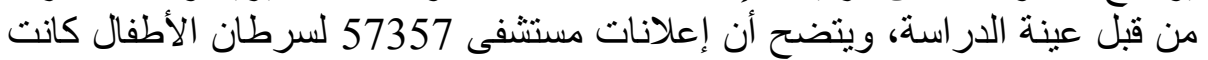

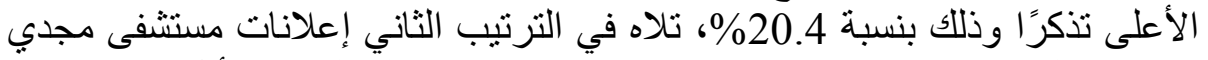
يعقوب للقلب بنسبة 17.8\%، وكانت إعلانات مؤسسة بنك الطعام الأقل تذكرًا بنسبة

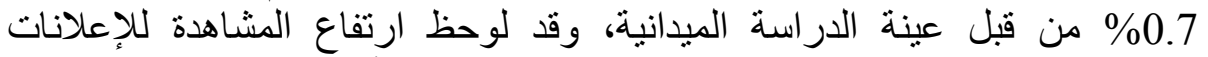

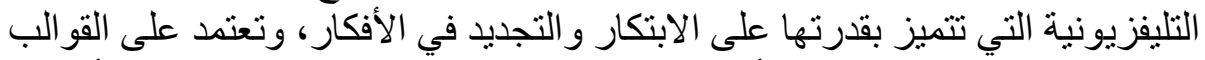

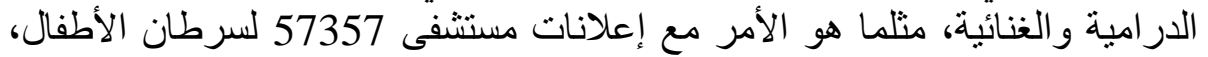
و مؤسسة مجدي يعقوب للقلب.

و تتفق النتائج السابقة مع ما أثنارت له كل من دون دراسة (إيمان سعد بسيوني بليح،

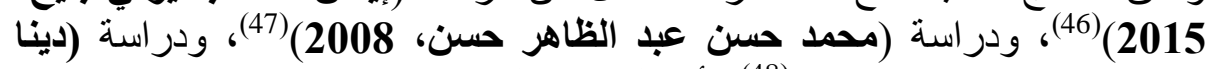

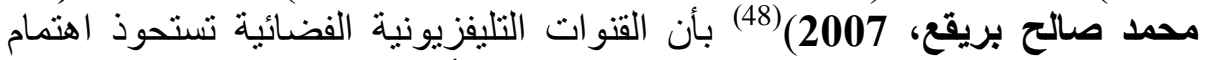

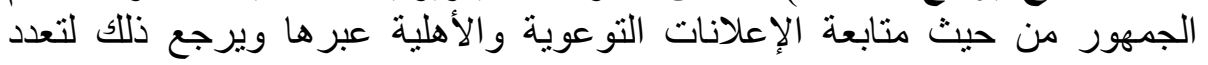


القنوات مما يتيح تتوع الفرص أمام المعلن، وبالتالي تقديم إعلانات التوعية الموجهة إلى كافة قطاعات الر أي العام حيث ثبوت نجام الفراح تأثير الإعلانات التليفزيونية في ذلك.

$$
\text { • اتجاهات عينة الاراسة نحو إعلانات المؤسسات الخيرية: }
$$

جدول رقم (4) اتجاهات عينة الاراسة من الثباب المصري نحو إعلانات

$$
\text { المؤسسات الخيرية الثنة }
$$

\begin{tabular}{|c|c|c|c|c|c|c|c|c|c|}
\hline \multirow{2}{*}{ المزان } & \multicolumn{2}{|c|}{ الإجمالي } & \multicolumn{2}{|c|}{ معارض معر } & \multicolumn{2}{|c|}{ 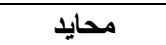 } & \multicolumn{2}{|c|}{ موافق } & \\
\hline & $\%$ & ك & $\%$ & ك & $\%$ & ك & $\%$ & ك & \\
\hline 88 & 100 & 200 & 6.5 & 13 & 11 & 22 & 82.5 & 165 & تتصف بالابتزازية وأقرب \\
\hline 86.8 & 100 & 200 & 6 & 12 & 14.5 & 29 & 79.5 & 159 & تنتهاك حقوق الإنسان \\
\hline 84.5 & 100 & 200 & 7 & 14 & 17 & 34 & 76 & 152 & تتعدى على خصوصيات \\
\hline 79.3 & 100 & 200 & 6 & 12 & 29.5 & 59 & 64.5 & 129 & ستار لجمع الأمو ال \\
\hline 27 & 100 & 200 & 50.5 & 101 & 45 & 90 & 4.5 & 9 & تثير الأمل والتفاؤل \\
\hline 27 & 100 & 200 & 47.5 & 95 & 51 & 102 & 1.5 & 3 & تسأوجد دفى تعريف الفردات \\
\hline 26.3 & 100 & 200 & 52 & 104 & 43.5 & 87 & 4.5 & 9 & تنتشر فكرة التكافل بين \\
\hline 22.5 & 100 & 200 & 59.5 & 119 & 36 & 72 & 4.5 & 9 & تثير التعاطف و الرحمة \\
\hline
\end{tabular}

يكثف الجدول السابق عن اتجاه عينة الدراسة نحو التقييم السلبي لإعلانات المؤسسات الخيرية التي تبث خلال شهر رمضاه

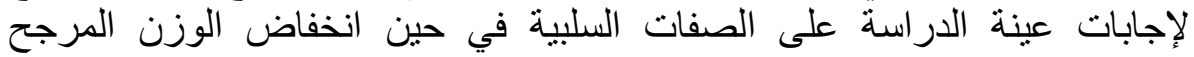

$$
\text { للصفات الإيجابية. }
$$

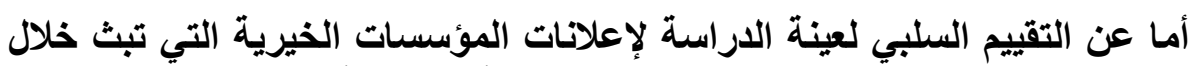

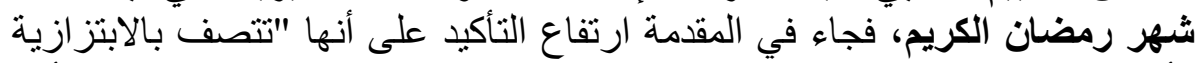
و أقرب للتسول" بوزن مرجح "88" درجة، نتلاه في الترتيب الثاني وصفها التانيا بأنها

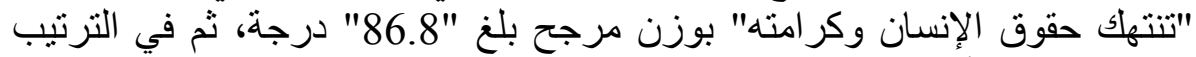

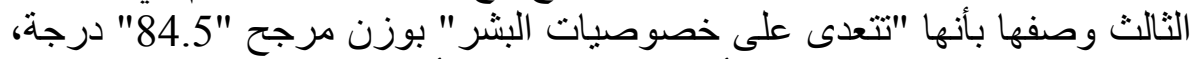

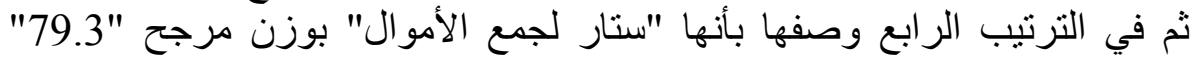

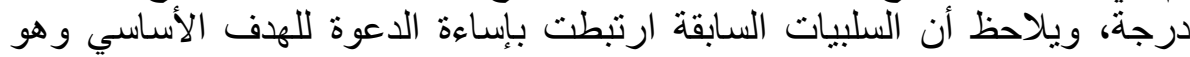

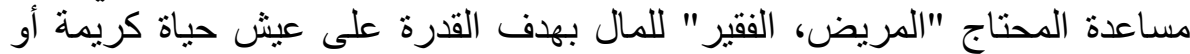
العلاج من الأمراض، حيث في إطار الدعوة للتكافل يتم الإمعان في بعض الفرل الإعلانات 


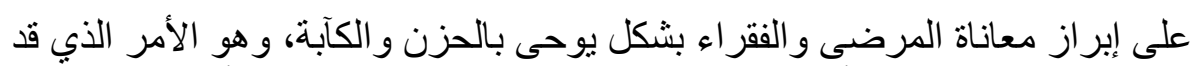

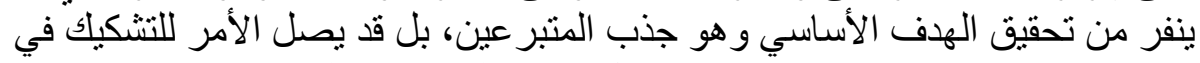
مصداقية الرسالة الإعلانية وتفسير ها بشكل مغاير للهدف المطنب المطلوب.

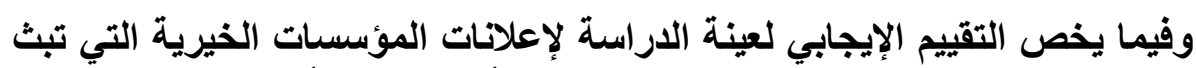

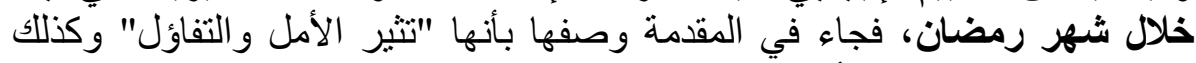

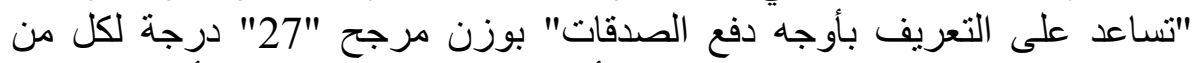

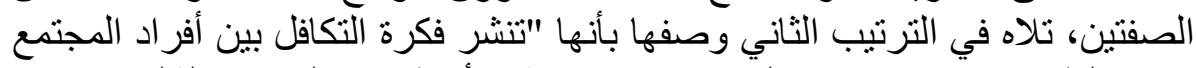

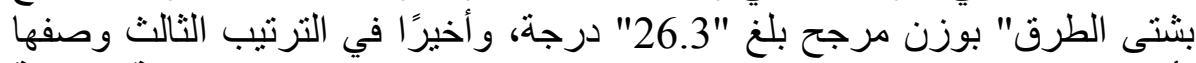

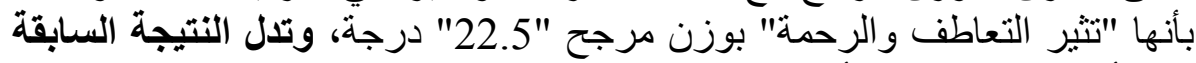

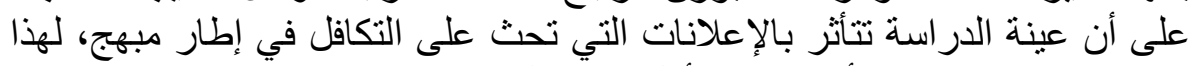

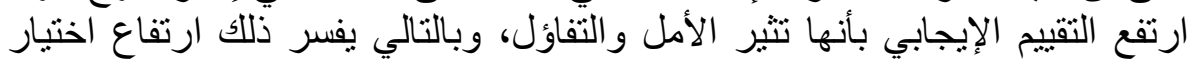

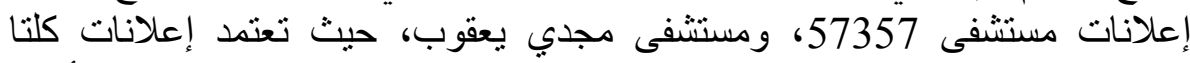

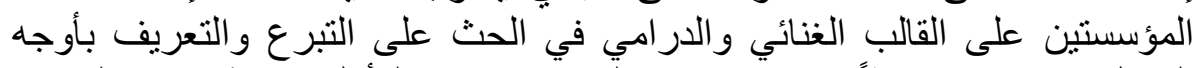

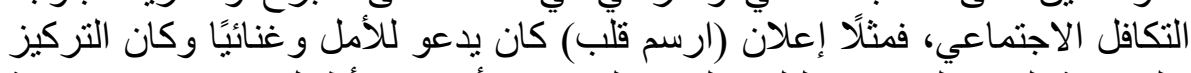

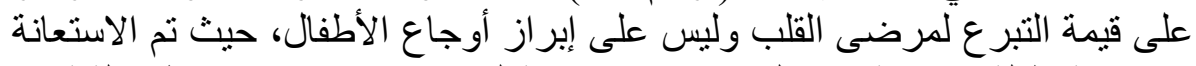

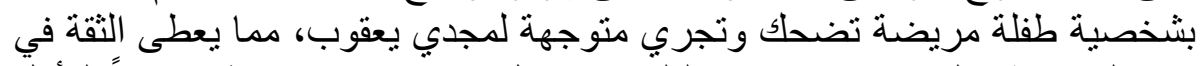

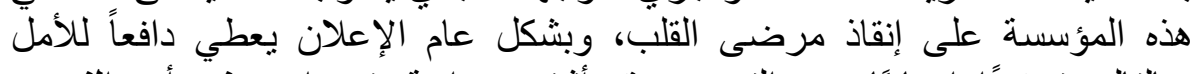

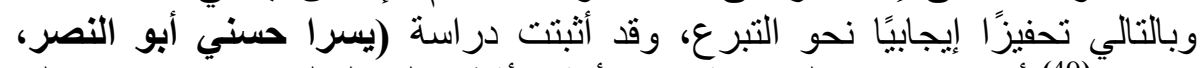

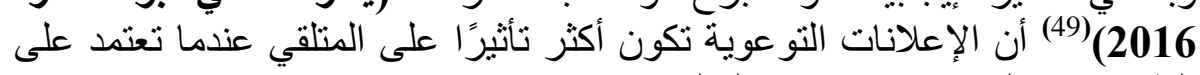
الطرق غير المباشرة في توجيه المتلقي.

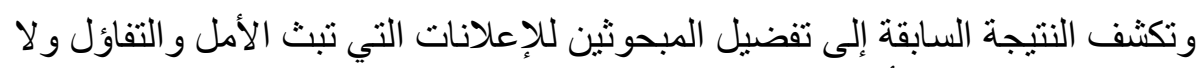

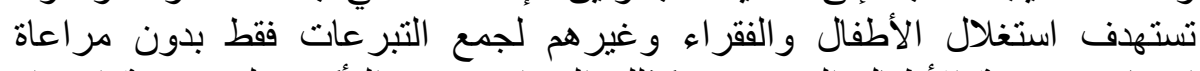

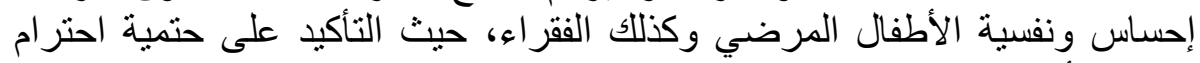

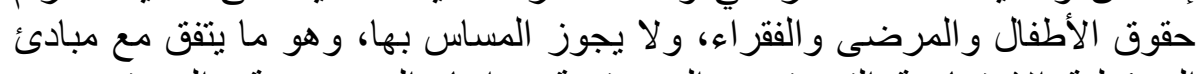

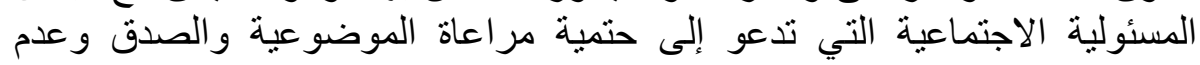

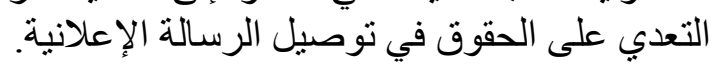

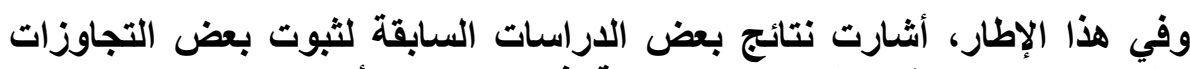

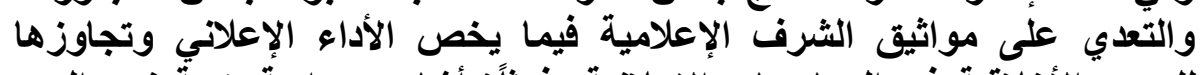

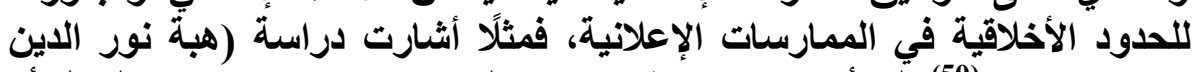

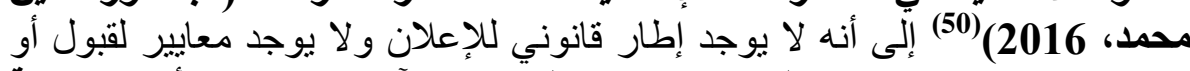

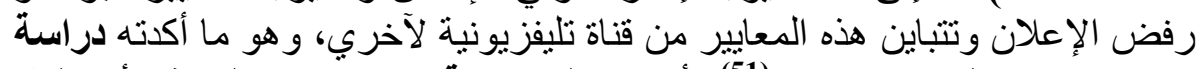

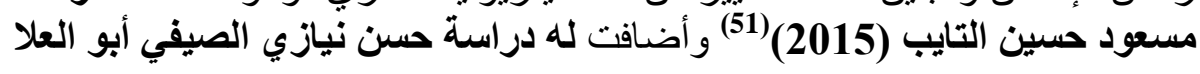


(2010)(52) بأن التجاوز الأخلاقي للإعلان المقدم عبر الفضائيات العربية أصبح سمة وحقيقة لا يمكن إنكار ها أو تجأهلها.

ويستخلص من إجابات عينة الدراسة على الجدول السابق مستويات اتجاهات عينة

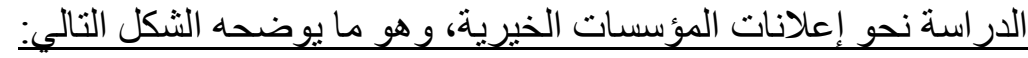

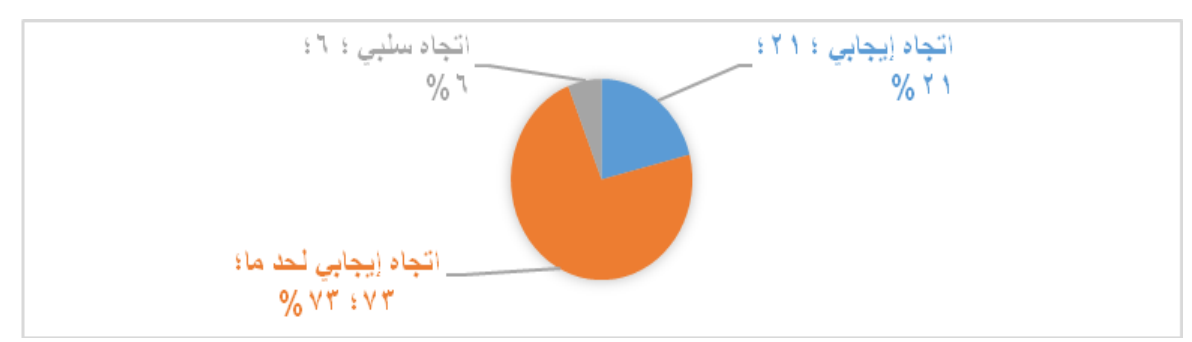

شكل رقم (6) مستويات اتجاهات عينة الدراسة نحو إعلانات المؤسسات

$$
\text { الخيرية }
$$

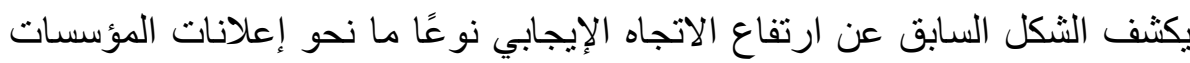

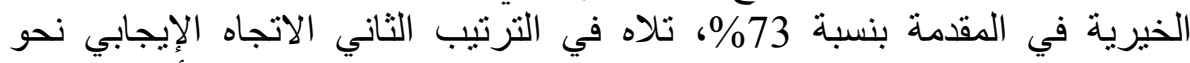

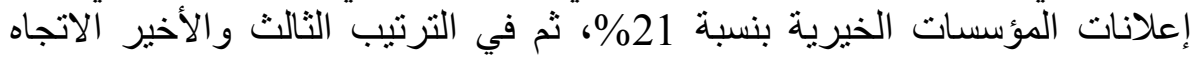
السلبي نحو إعلانات المؤسسات الخيرية بنسبة \% \% \%

والذكرها: الثانى: العوامل المتعلقة بمضمون الرسالة الإعلانية للمؤسسات الخيرية جدول رقم (5) أكثر العناصر التي تتذكرها عينة الدراسة في الإعلان التلفزيوني

\begin{tabular}{|c|c|c|c|c|c|c|c|c|c|}
\hline \multirow{2}{*}{ المرجح } & \multicolumn{2}{|c|}{ الإجمالي } & \multicolumn{2}{|c|}{ معارض } & \multicolumn{2}{|c|}{ محايد } & \multicolumn{2}{|c|}{ موافق } & \multirow[t]{2}{*}{ العناصر } \\
\hline & $\%$ & ك & $\%$ & ك5 & $\%$ & ك5 & $\%$ & ك5 & \\
\hline 36.3 & 100 & 200 & 35 & 70 & 57.5 & 115 & 7.5 & 15 & الحوار الدر امي بالإعلان \\
\hline 30.5 & 100 & 200 & 43.5 & 87 & 52 & 104 & 4.5 & 9 & الشخصيات اللموجودة \\
\hline 27 & 100 & 200 & 47.5 & 95 & 51 & 102 & 1.5 & 3 & المعلومات التي وردت \\
\hline 22 & 100 & 200 & 60.5 & 121 & 35 & 70 & 4.5 & 9 & أماكن وديكور التصوير \\
\hline 13.5 & 100 & 200 & 74.5 & 149 & 24 & 48 & 1.5 & 3 & موسيقى و أغنية الإعلان \\
\hline 11.8 & 100 & 200 & 78.5 & 157 & 19.5 & 39 & 2 & 4 & فكرة الإعلان \\
\hline
\end{tabular}

تتتوع العناصر التي تتذكرها عينة الدراسة في الإعلان التليفزيوني الخاص بالمؤسسات الخيرية كما يوضحها الجدول السابق وإن كانت درجات الإنهات الوزن المرجح 


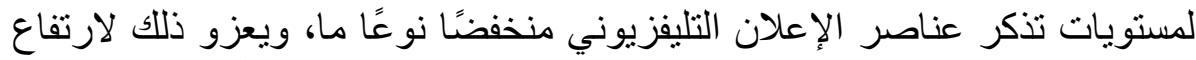

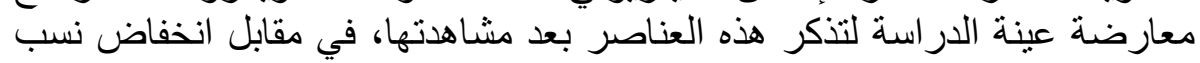
عينة الدر اسة التي تتذكر هذه العناصر.

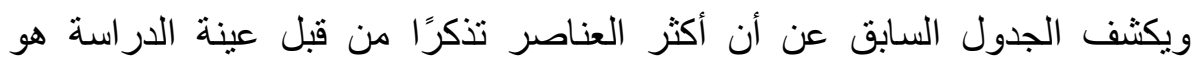

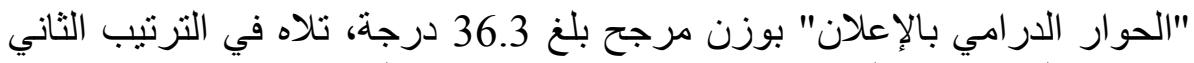

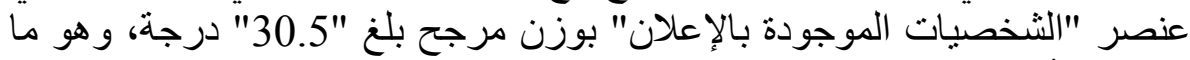

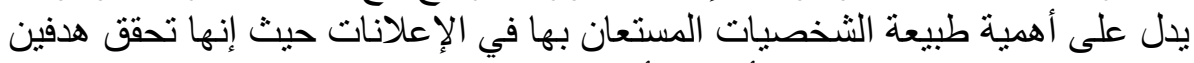

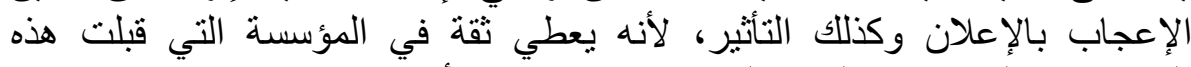

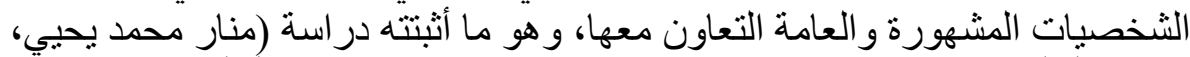

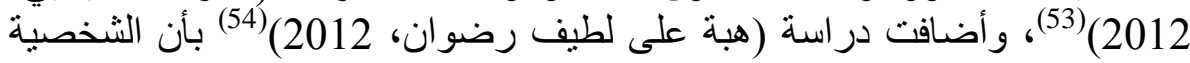

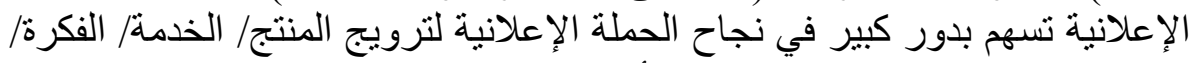

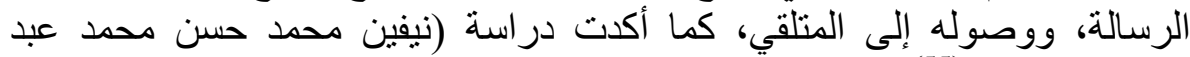

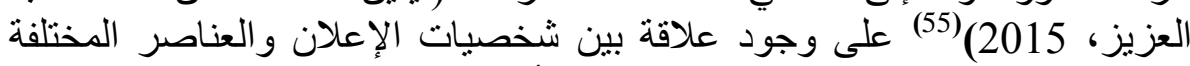

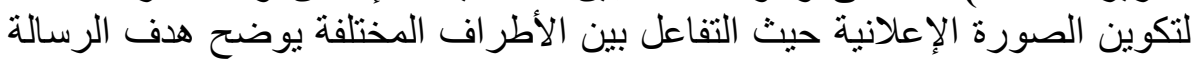
الإعلانية.

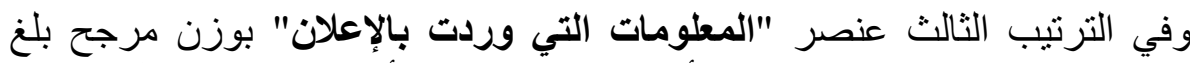

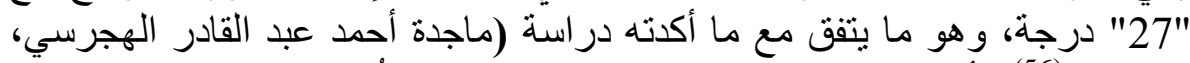

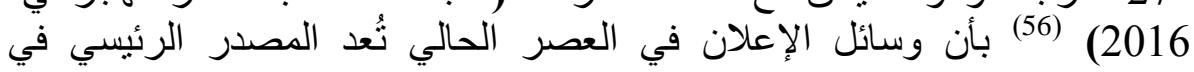

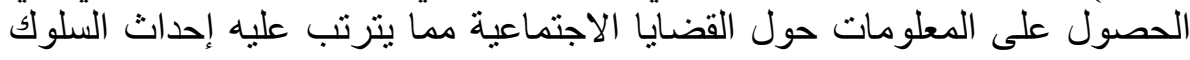
الإيجابي المجتمعي.

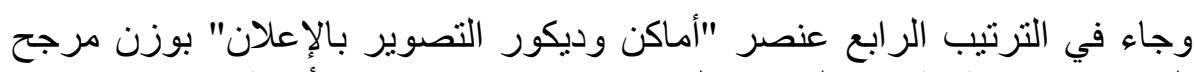

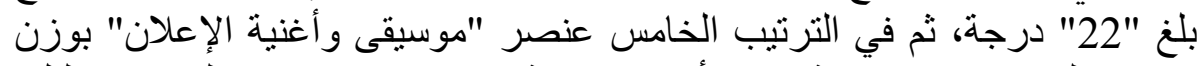

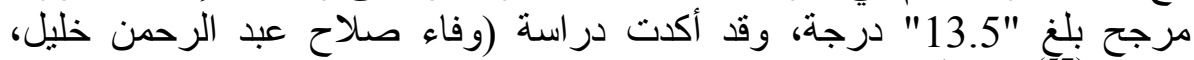

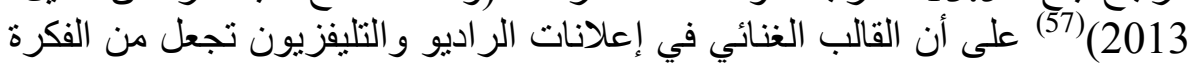
الإعلانية أكثر إعجابًا وتذكرًا من جانب الفئل المنلقي.

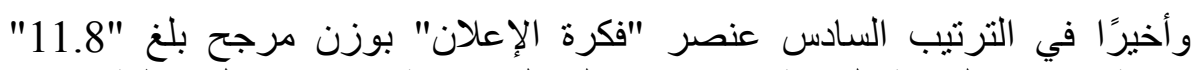

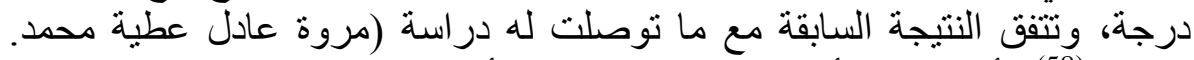

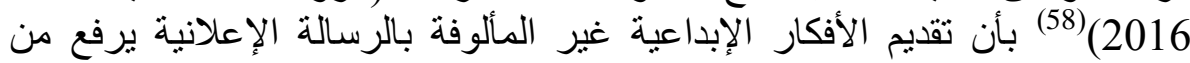

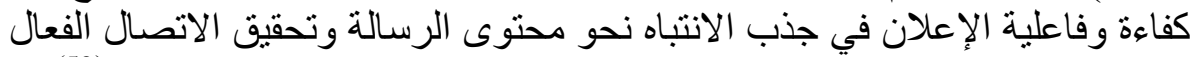

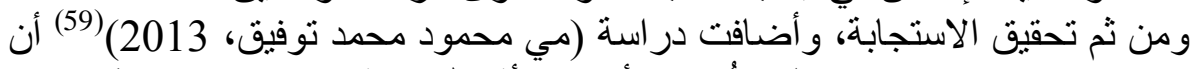

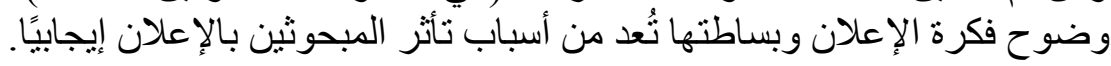

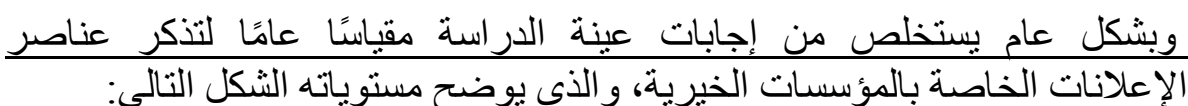




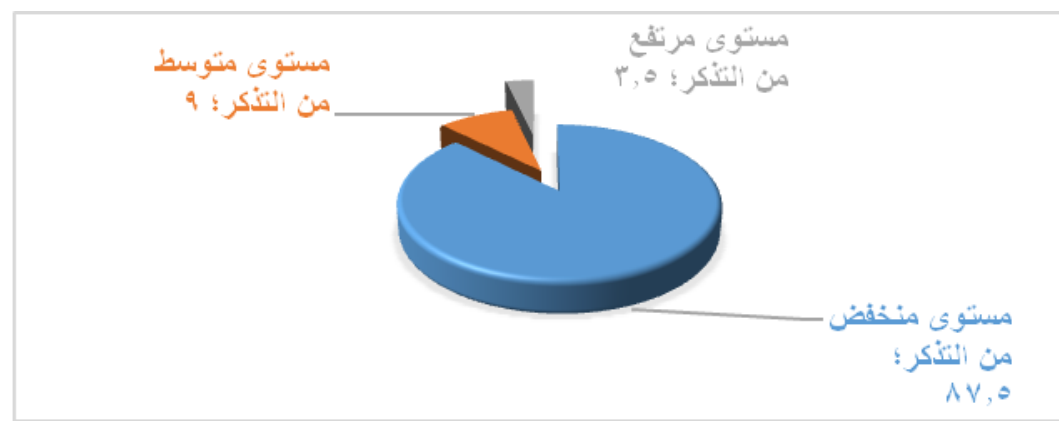

شكل رقم (7) مستويات تذكر عينة الدراسة لعناصر إعلانات المؤسسات الخيرية

يكثف الثكل السابق عن انخفاض مستوى تذكر نسبة 87.5\% من عينة الدراسة

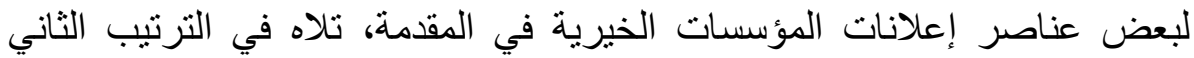

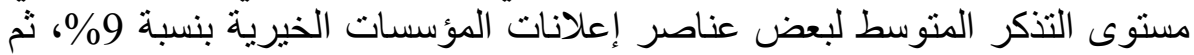

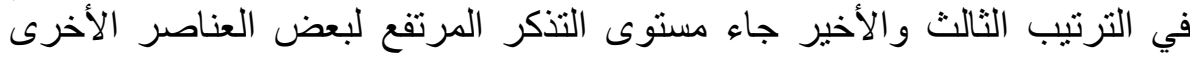

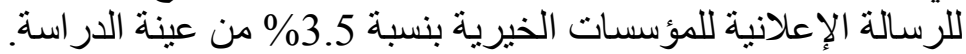

$$
\text { • العوامل المتعلقة بمضمون إعلانات المؤسسات الخيرية: }
$$

\section{جدول رقم (6) العوامل المتعلقة بمضمون إعلانات المؤسسات الخيرية}

\begin{tabular}{|c|c|c|c|c|c|c|c|c|c|}
\hline \multirow{2}{*}{ المرجح المز } & \multicolumn{2}{|c|}{ الإجمالي } & \multicolumn{2}{|c|}{ معارض } & \multicolumn{2}{|c|}{ محايد } & \multicolumn{2}{|c|}{ موافق } & \multirow[t]{2}{*}{ العبارات } \\
\hline & $\%$ & S & $\%$ & 5 & $\%$ & 5 & $\%$ & 5 & \\
\hline 72.3 & 100 & 200 & 14 & 28 & 27.5 & 55 & 58.5 & 117 & التخويف أُ إلارة المشاعر) العاطفية (التز غيب أو \\
\hline 36.5 & 100 & 200 & 39 & 78 & 49 & 98 & 12 & 24 & الإعلانية بعض المعلومات الهامة فى الرسالة \\
\hline 29 & 100 & 200 & 49 & 98 & 44 & 88 & 7 & 14 & قيامه بسلوك الفو الثبر التي تعد مشاهدة على الإعلان نتيجة \\
\hline 25.8 & 100 & 200 & 51 & 102 & 46.5 & 93 & 2.5 & 5 & توصيل الرسالة الإعلانية الأنت الدرامية على \\
\hline 25.3 & 100 & 200 & 51.5 & 103 & 46.5 & 93 & 2 & 4 & صدق وتأثير الثخصيات الاستشهادية \\
\hline 21 & 100 & 200 & 60 & 120 & 38 & 76 & 2 & 4 & التعريف بنشاط المؤسسة وإنجاز اتها \\
\hline 10.3 & 100 & 200 & 80 & 160 & 19.5 & 39 & 0.5 & 1 & والبراهين العلمية). \\
\hline 8 & 100 & 200 & 85 & 170 & 14 & 28 & 1 & 2 & ابتكار الأفكار الإعلانية وحداثثها \\
\hline
\end{tabular}

تتنوع العوامل التي تهنم عينة الدراسة بوجودها في إي رسالة إعلانية تقدمها

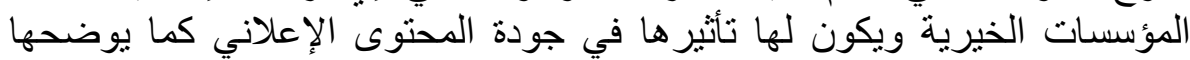
الجدول السابق، وإن كانت درجات الوزن المرجح لمستويات الاهتمام بهذه العات العناصر 


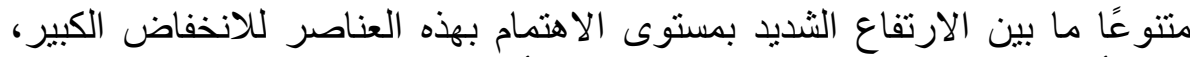

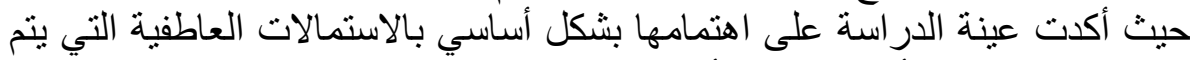

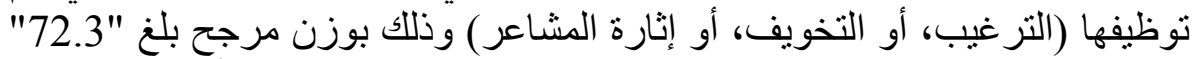

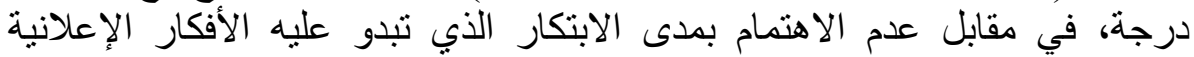

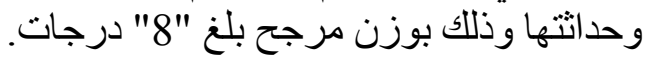

وفيما يتعلق بتأثير توظيف الاستمالات العاطفية في إعلانات الجمعيات الأهلية، فقد توصلت دراسة (2013.Magdalini Tsoutsoumpi)

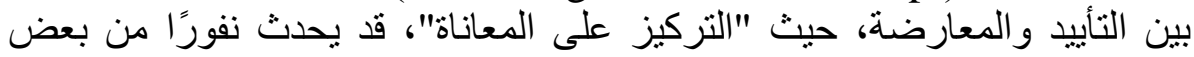

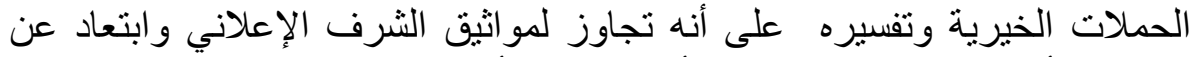

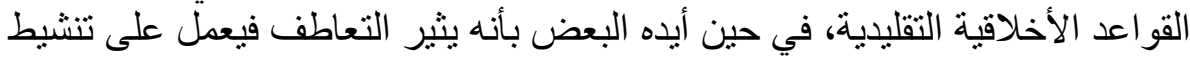

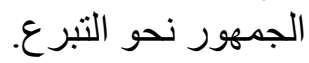

ويأتي في الترتيب الثاني من حيث العناصر التي تهنم عينة الدراسة بوجودها في التياتي

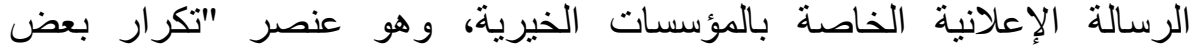

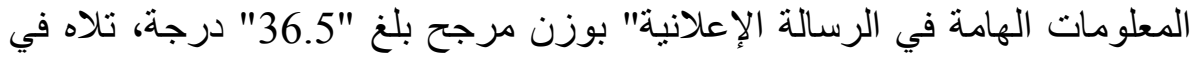

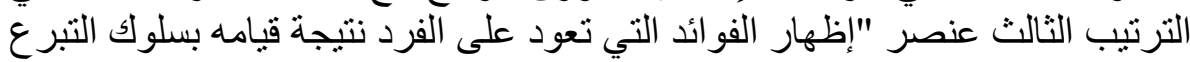

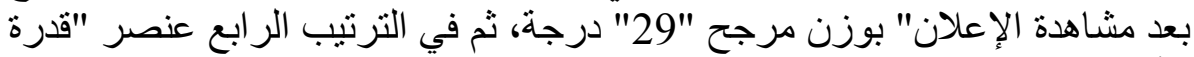

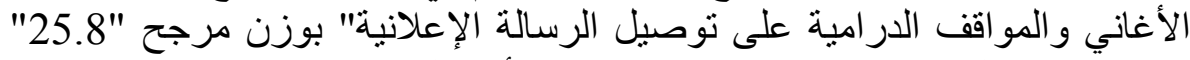

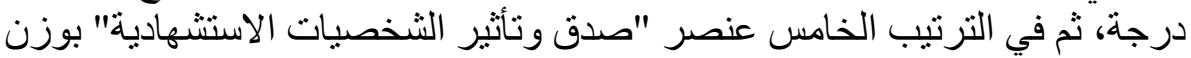

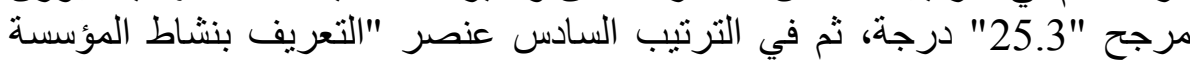

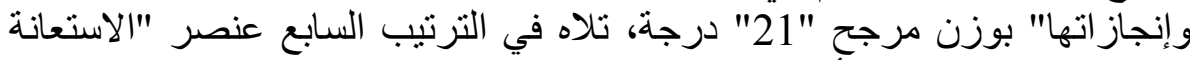
بالاستمالات العقلانية "الأدلة و البر اهين العلمية" بوزن تون مرجح "10.3" درجة.

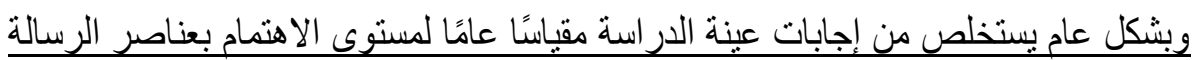

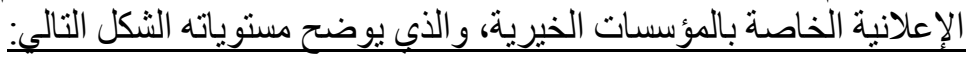

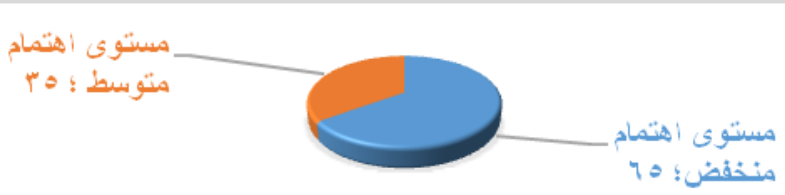

شكل رقم (8) مستويات اهتمام عينة الدراسة بعناصر الرسالة الإعلانية

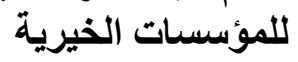

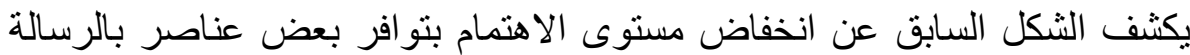

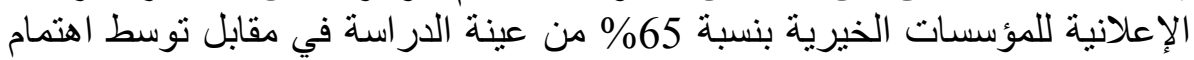

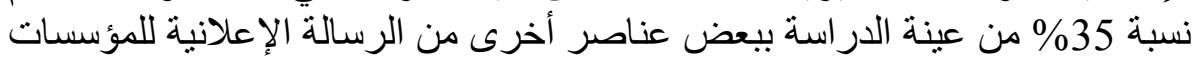


• مصداقية الثخصيات التي يتم الاستعانة بها في إعلانات المؤسسات الخيرية:

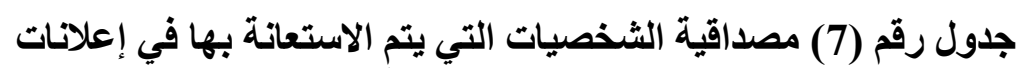
المؤسسات الخيرية التية

\begin{tabular}{|c|c|c|c|c|c|c|c|c|c|}
\hline \multirow{2}{*}{ المرجح } & \multicolumn{2}{|c|}{ الإجمالي } & \multicolumn{2}{|c|}{ معارض } & \multicolumn{2}{|c|}{ محايد } & \multicolumn{2}{|c|}{ موافق } & \multirow[t]{2}{*}{ طبيعة الثخصيات } \\
\hline & $\%$ & 5 & $\%$ & ك & $\%$ & st & $\%$ & ك & \\
\hline 50.3 & 100 & 200 & 36 & 72 & 27.5 & 55 & 36.5 & 73 & رجال دين \\
\hline 49.3 & 100 & 200 & 28 & 56 & 45.5 & 91 & 26.5 & 53 & رياضيين \\
\hline 44 & 100 & 200 & 32.5 & 65 & 47 & 94 & 20.5 & 41 & فنانين \\
\hline 44 & 100 & 200 & 41.5 & 83 & 29 & 58 & 29.5 & 59 & 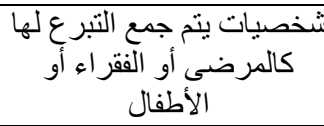 \\
\hline 25.5 & 100 & 200 & 53.5 & 107 & 42 & 84 & 4.5 & 9 & عاملين بالمؤسسات الخيرية \\
\hline 21.8 & 100 & 200 & 64 & 128 & 28.5 & 57 & 7.5 & 15 & المسئولين بالدولة \\
\hline 21.3 & 100 & 200 & 59.5 & 119 & 38.5 & 77 & 2 & 4 & شخصيات عادية من المجتص \\
\hline
\end{tabular}

تتنوع مصداقية طبيعة الثخصيات التي يتم الاستعانة بها في إعلانات المؤسسات

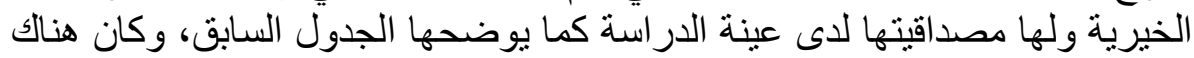

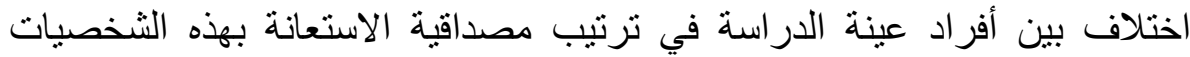

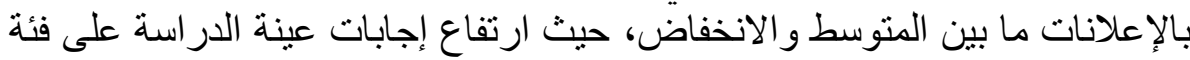

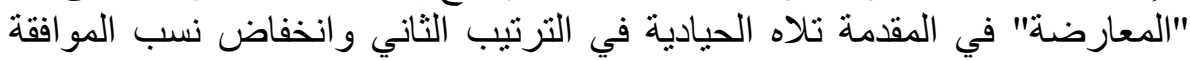
على مصداقية هذه الثخصيات بالإعلانات.

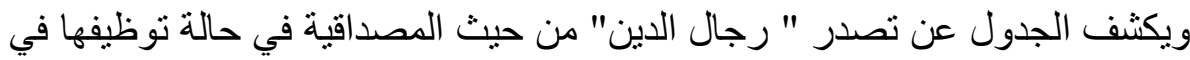

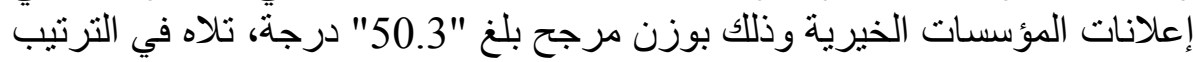

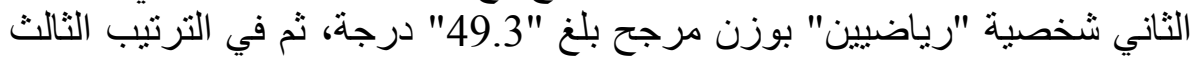

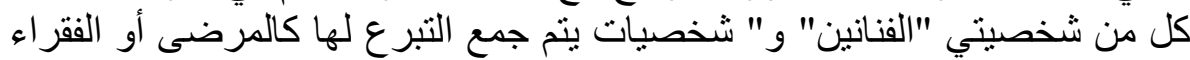

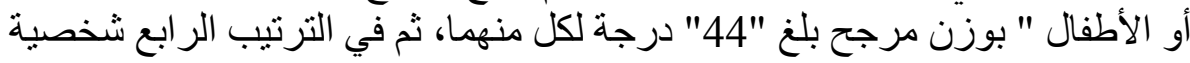

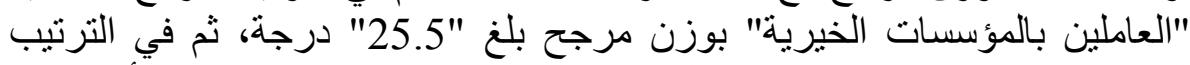

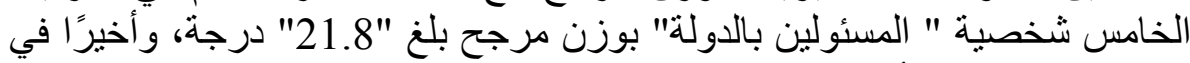
الترنيب السادس والأخير جاءت "الثخصيات العادية من المجتمع" بوزن لئن مرجح بلغ "21.3" درجة.

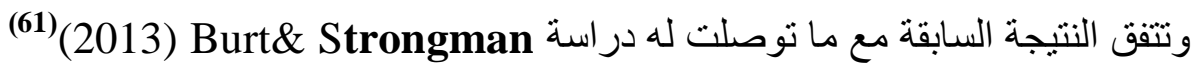

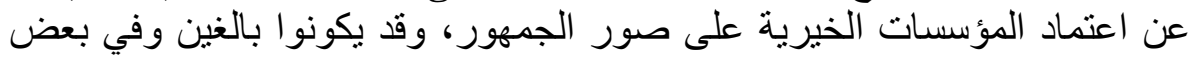

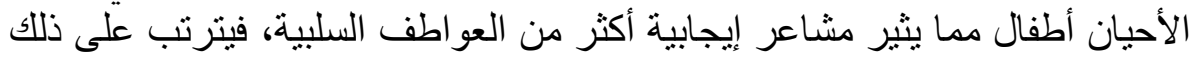
تحفيز عملية التبرع المادي. 
وبشكل عام يستخلص من إجابات عينة الدراسة مقياسًا عامًا لمستوى مصداقية

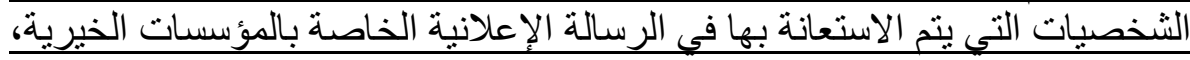
و الذي يوضح مستوياته الثكل التالئي:

\begin{tabular}{|c|c|c|c|c|c|c|c|c|c|}
\hline & & & & & & & & & \\
\hline لي عداقية & تُعانة & خُ & سَّة عية & مد - ميها & نونو & ضينة & بل بير من بنة & 7. & 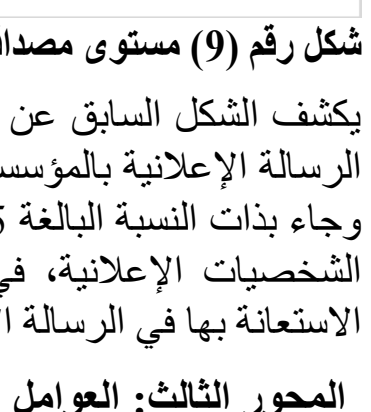 \\
\hline 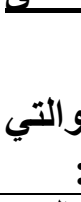 & مضر & نُنهر & & & & & & & سلوك التبرع: \\
\hline المرجن المز & \% & 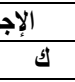 & $\%$ & 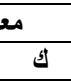 & $\%$ & s & ف ف & 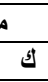 & العوامل \\
\hline 62.3 & 100 & 200 & 12 & 24 & 51.5 & 103 & 36.5 & 73 & تكرار عرض الإعلانات على مدار \\
\hline 32.5 & 100 & 200 & 43.5 & 87 & 48 & 96 & 8.5 & 17 & عرض إعلانات المؤسسات الخيرية فئية في \\
\hline 31.8 & 100 & 200 & 40.5 & 81 & 55.5 & 111 & 4 & 8 & أماكن تصوير الرسالة الإعلانية يؤثر \\
\hline 26 & 100 & 200 & 51.5 & 103 & 45 & 90 & 3.5 & 7 & 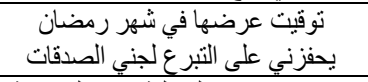 \\
\hline 23.8 & 100 & 200 & 56.5 & 113 & 39.5 & 79 & 4 & 8 & تنتوع الإعلانات المتعلقة بذات المؤسئسة \\
\hline 22.5 & 100 & 200 & 58 & 116 & 39 & 78 & 3 & 6 & الختوع الرسائل الإعلانية لذات المئل المؤسسةة \\
\hline 10.3 & 100 & 200 & 80 & 160 & 19.5 & 39 & 0.5 & 1 & اللغة المستخدمة بالإعلان مناسبة \\
\hline
\end{tabular}


يكثف الجدول السابق عن تنوع العو امل المتعلقة بإدارة إعلانات المؤسسات الخيرية

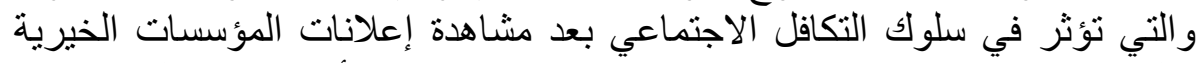

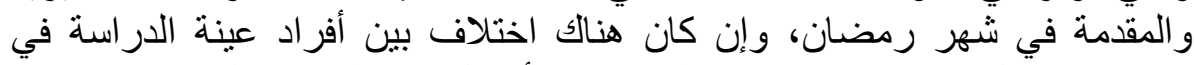

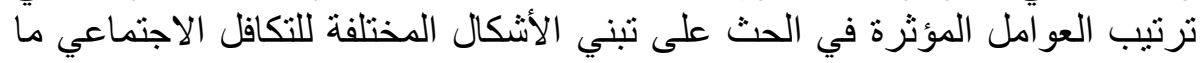

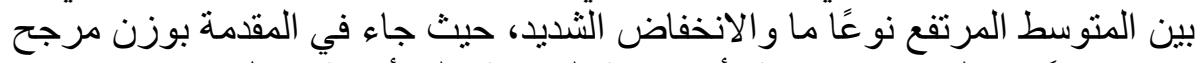

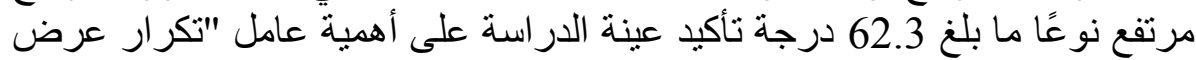

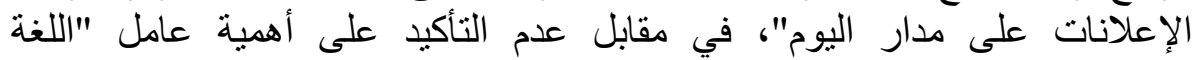

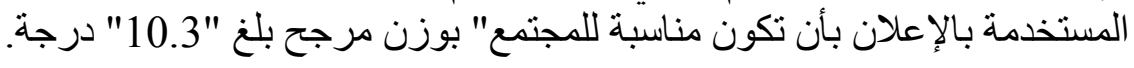

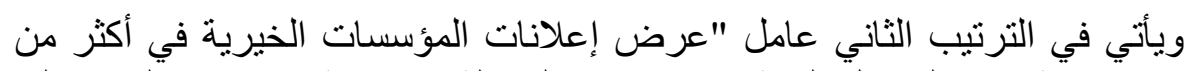

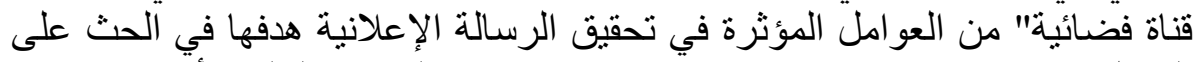

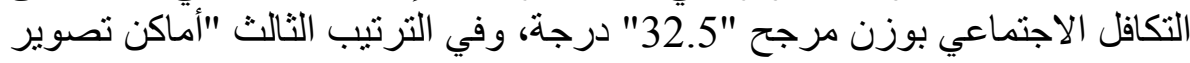

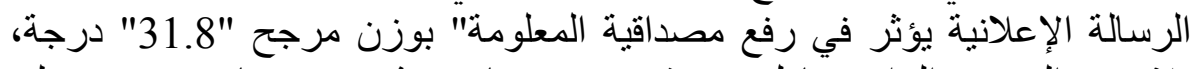

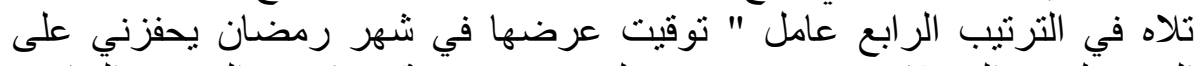

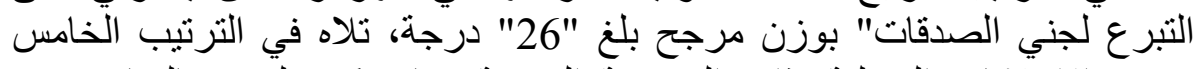

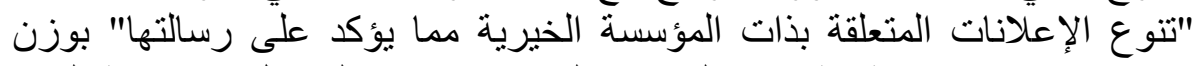

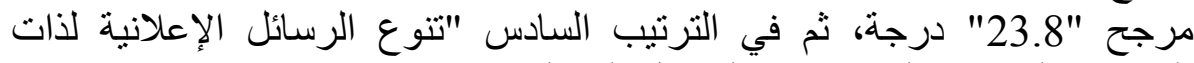
المؤسسة الخيرية على مستوى الوسائل المختلفة يدعم فكرة انتشار ها" بوزن الإند مرجح

$$
\text { "22.5" دروجة. }
$$

وبشكل عام بستخلص من إجابات عينة الدر اسة مقياسنًا عامًا لمستوى العو امل المؤثرة

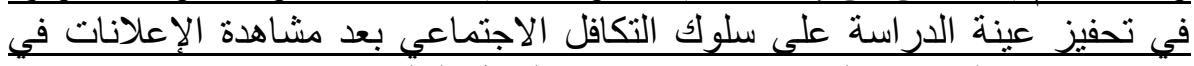

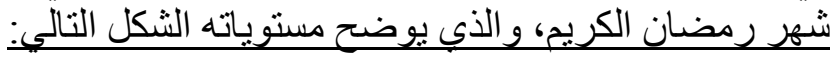

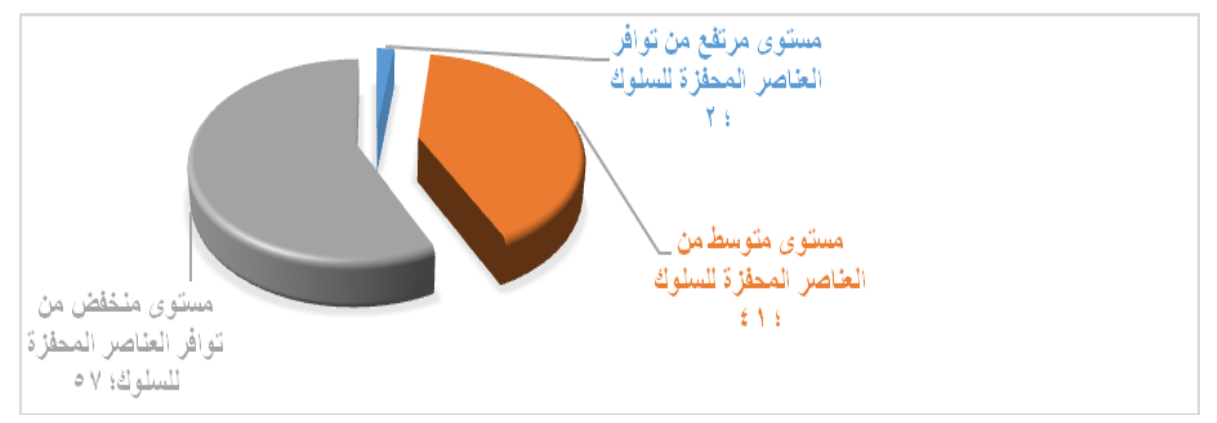

$$
\begin{aligned}
& \text { شكل رقم (10) مستويات تقييم عينة الدراسة للعناصر المحفزة للسلوك إعلات }
\end{aligned}
$$

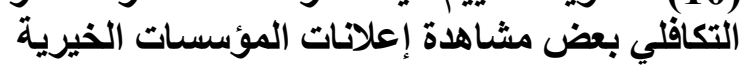

يكثف الثكل السابق عن انخفاض مستوى تو افر العناصر المحفزة للسلوك التكافلي

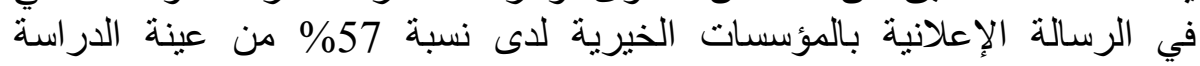




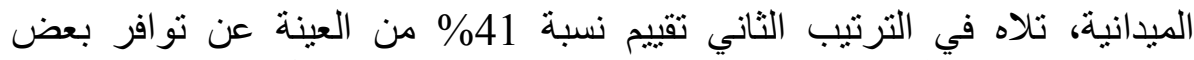

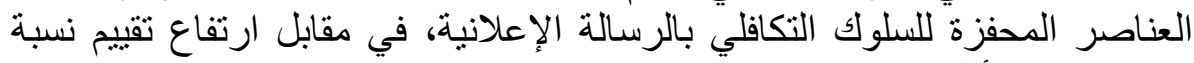

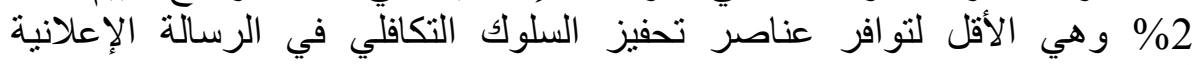
للمؤسسات الخيرية.

• شكل رقم (11) تقييم عينة الاراسة لمدى وجود تقارب ما بين الرسالة الإعلانية والواقع الفعلي:

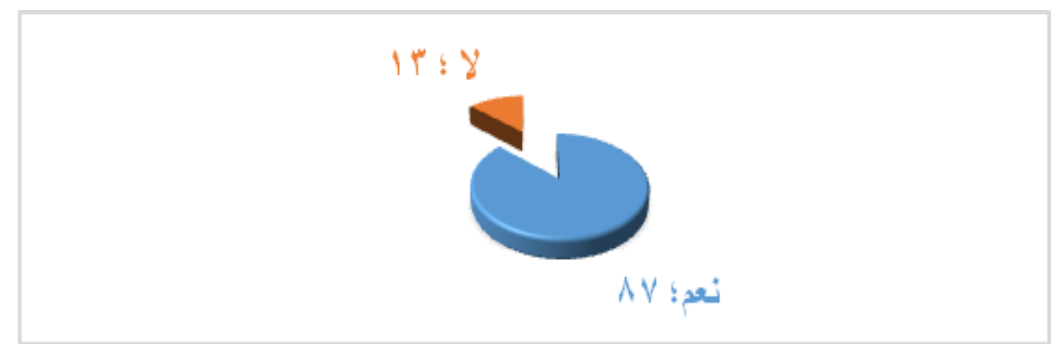

يكثف الثكل السابق عن ارتفاع موافقة عينة الدراسة على تأييد وجود تقارب بين

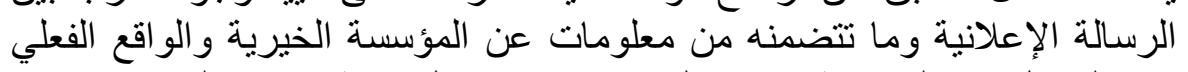

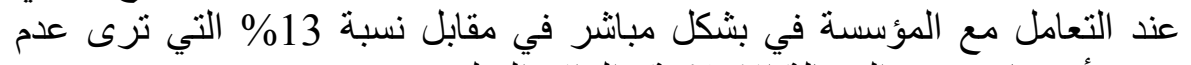

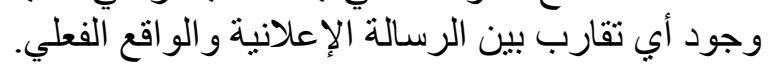

• شكل رقم (12) تقييم عينة الاراسة لتأثير خبرة التعامل المباشرة مع المؤسسات الخيرية في تصديق الرسبالة الإعلانية:

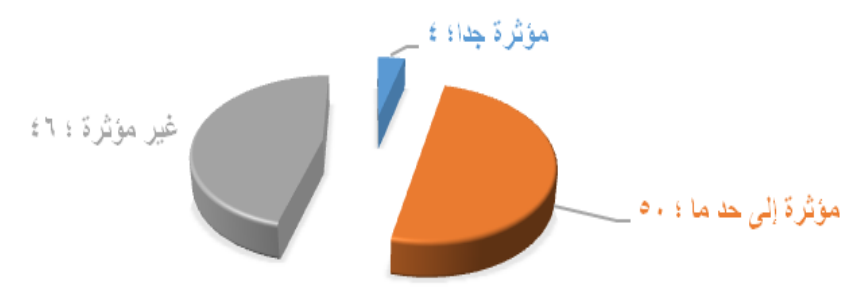

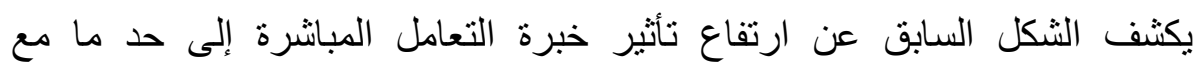

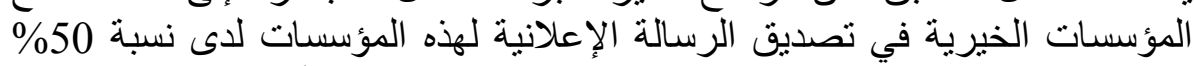

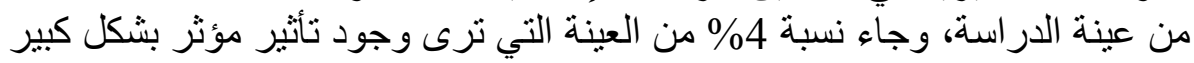

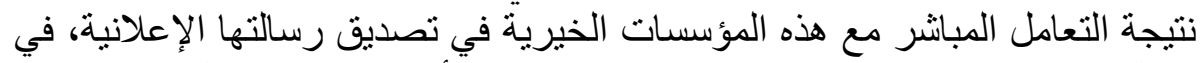

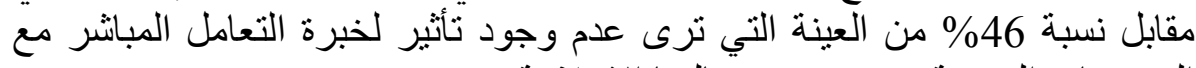
المؤسسات الخيرية في تصديق رسالتها الإعلانية. 


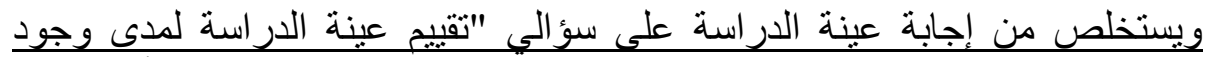

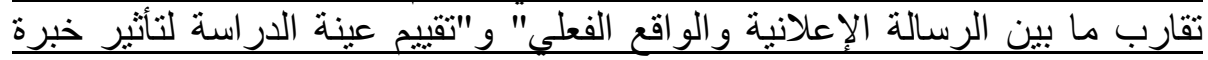

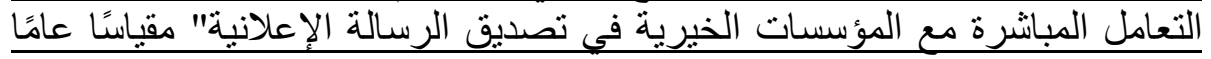

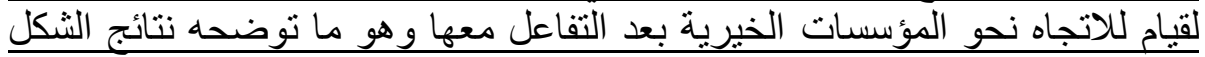
التالي:

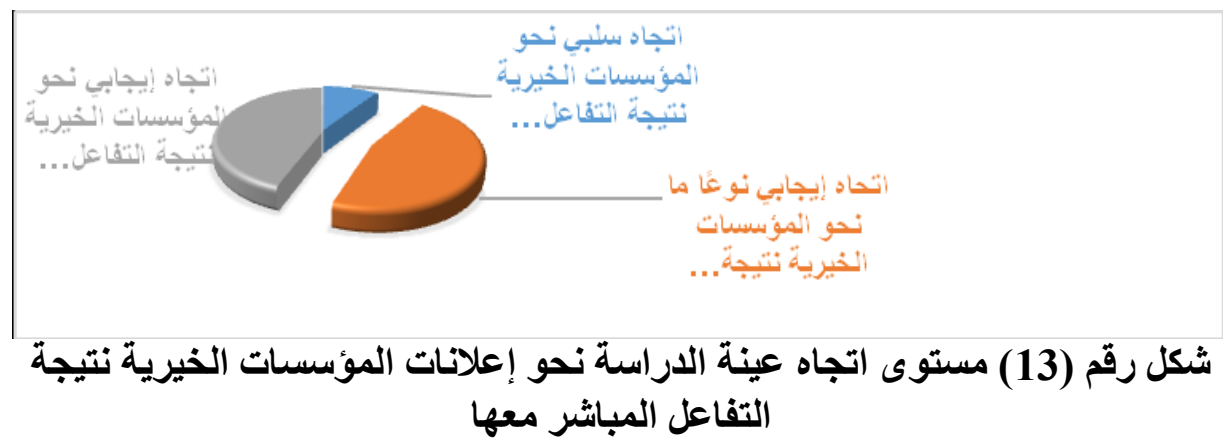

يكثف الثكل السابق عن تصدر الاتجاه الإيجابي نوعًا ما نحو المؤسسات الخيرية

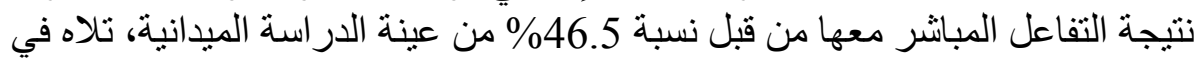

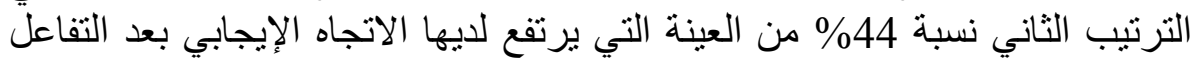

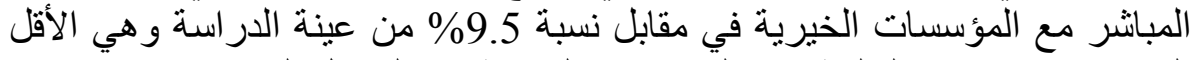
التي يتصف اتجاها بالسلبية نحو المؤسسات الخيرية فعد التبلة التعامل المباثر معها.

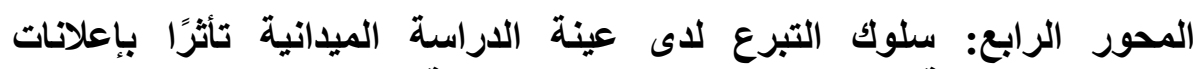
المؤسسات الخيرية التي تبث عبر القتوات التبرع التليفزيونية:

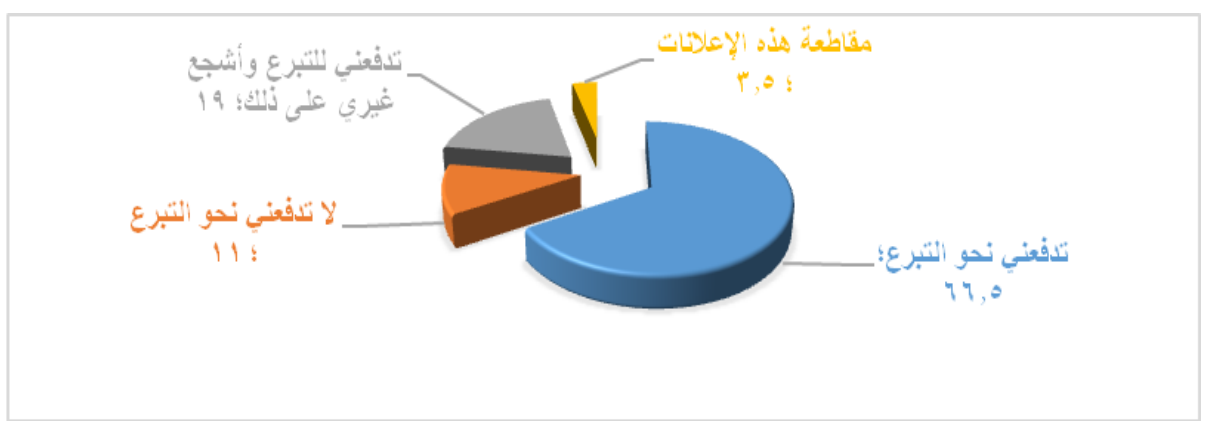

شـكل رقم (14) سـلوك عينـة الاراسـة بعـد مشــاهدة إعلانـات المؤسســات الخيريـة بخصوص التكاقل الاجتماعي: 
يكثف الثكل السابق عن ارتفاع قدرة إعلانات المؤسسات الخيرية التي كانت تبث في

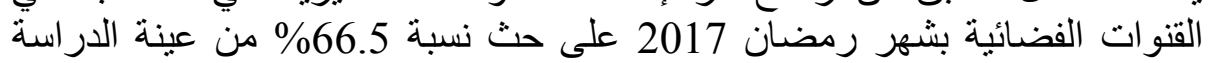

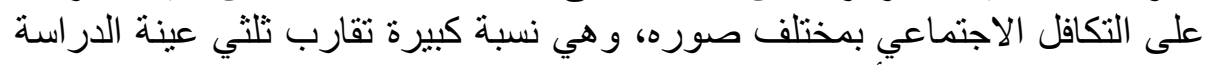

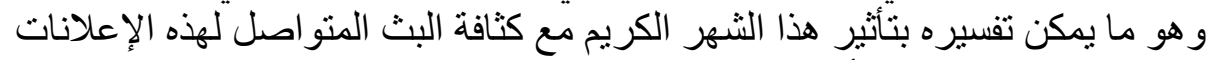

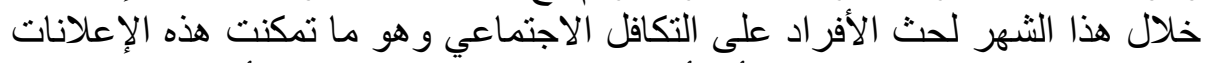

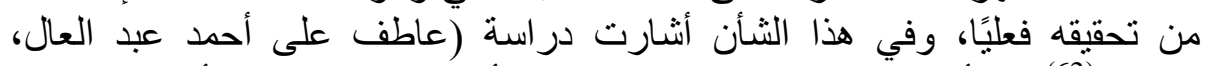

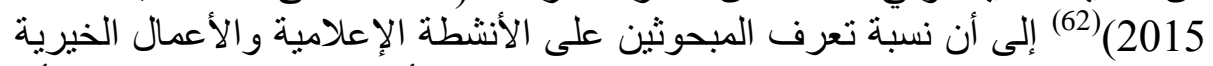

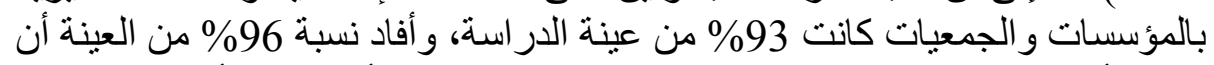

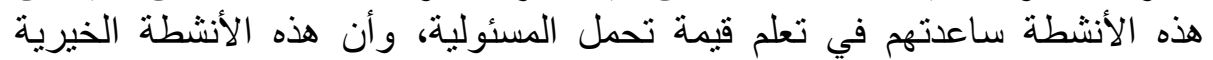

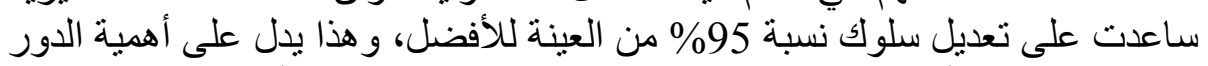

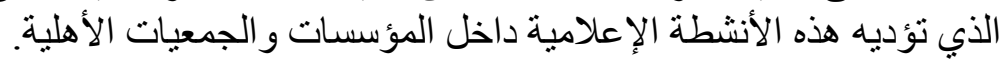

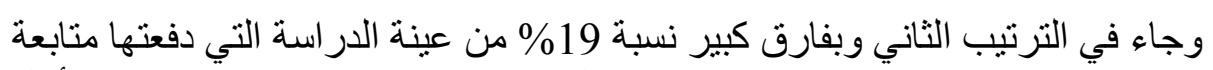

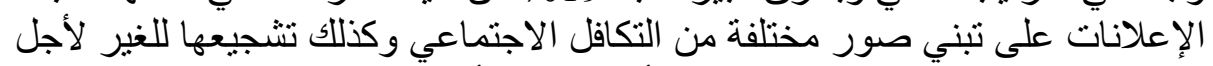

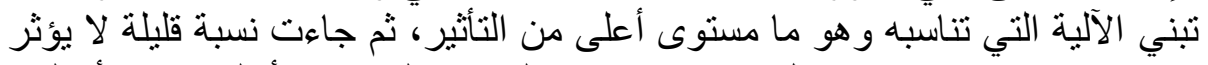

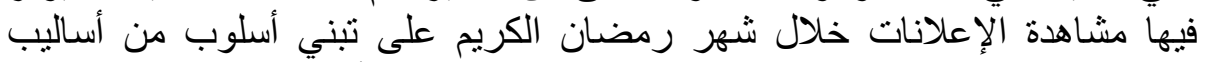

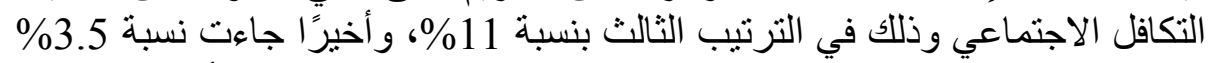

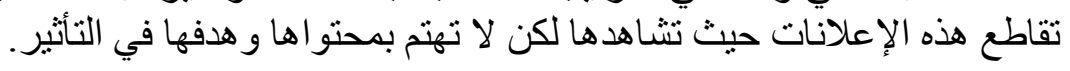

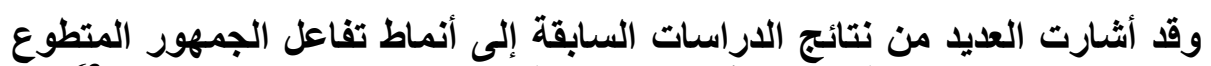

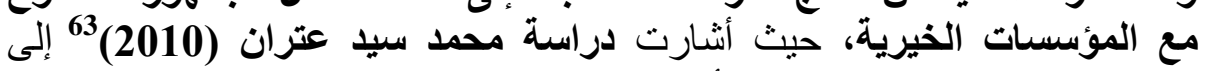

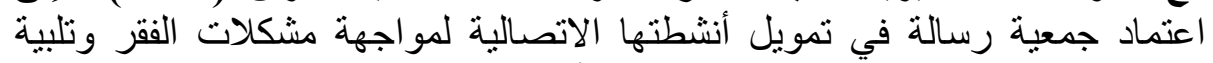

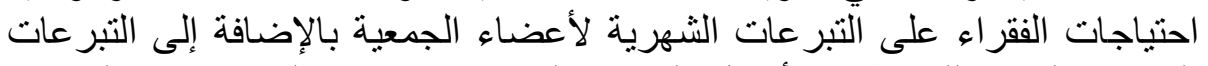

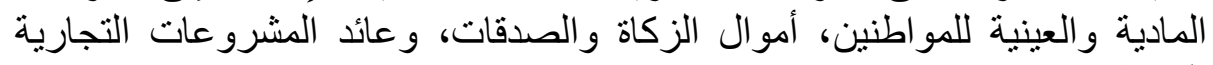
البسيطة.

كما أكدات دراسة وكر وحليقة (Bendell, walker and curl)

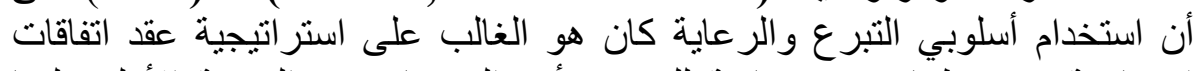

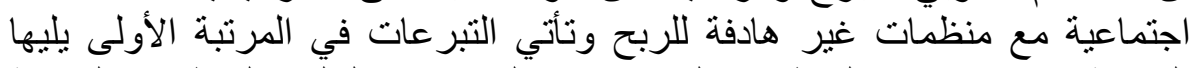

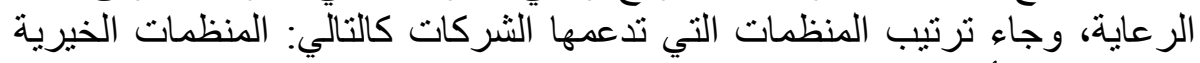

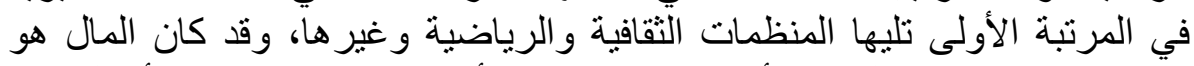

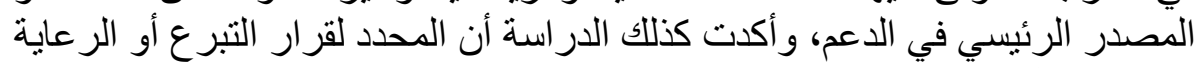
هم مديرو التسويق في الثركة. 


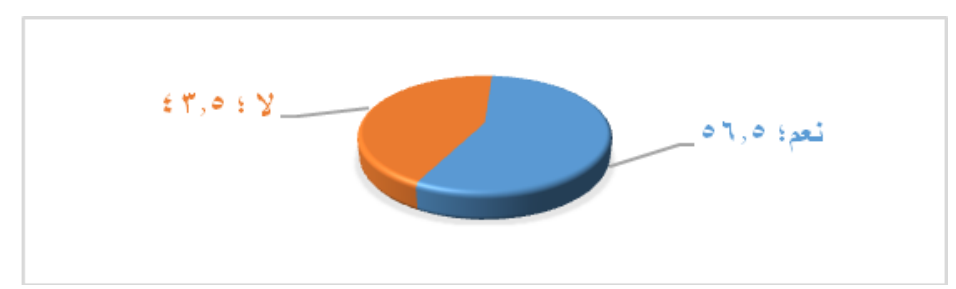

شكل رقم (15) تبرع عينة الدراسة للمؤسسات الخيرية بعد مشاهدة إعلاناتها في

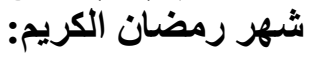

يكثف الثكل السابق عن ارتفاع سلوك التبرع بعد مشاهدة عينة الدراسة من الثباب

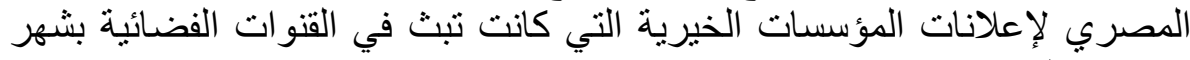

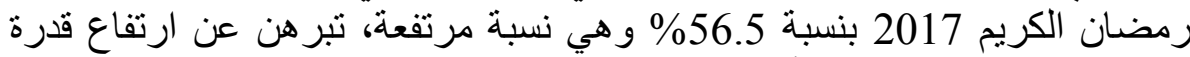

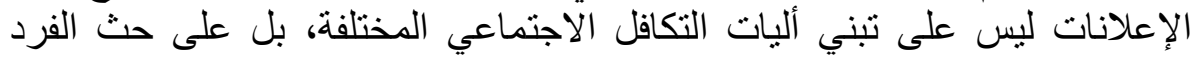

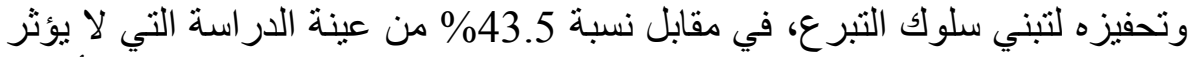

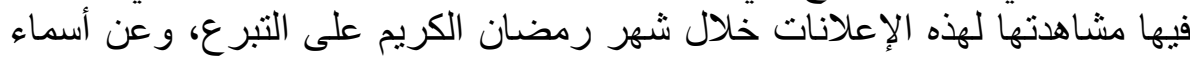

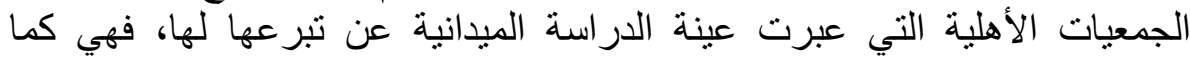

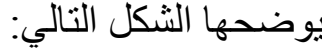

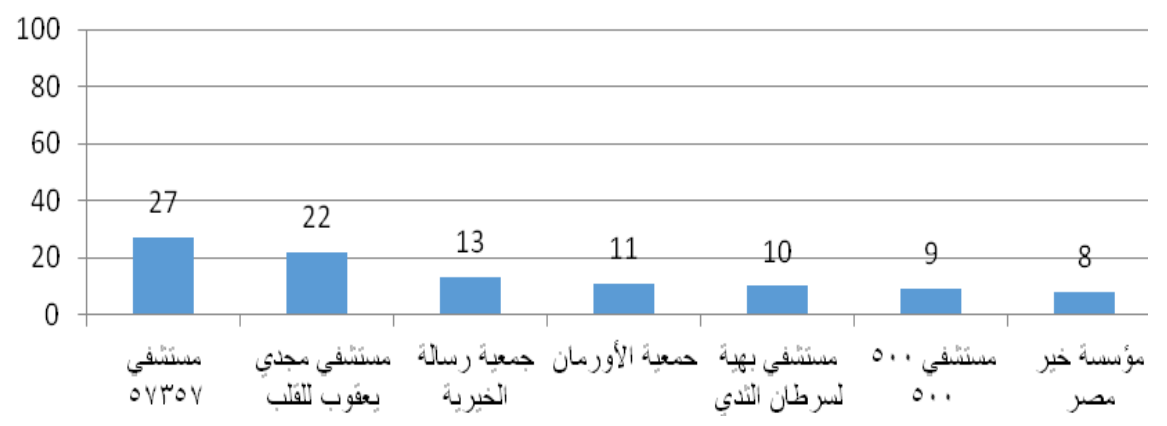

شكل رقم (16) أسماء المؤسسات الخيرية التي قامت عينة الدراسة بالتبرع لها لهات ويستخلص من إجابة عينة الدراسة على سؤ الي "سلوك عينة الدراسة بعد مشاهدة

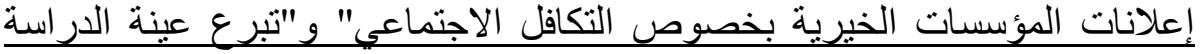

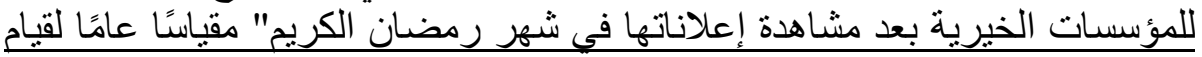

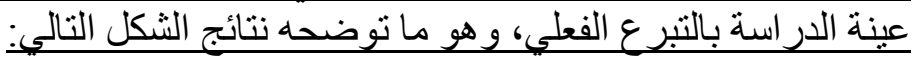




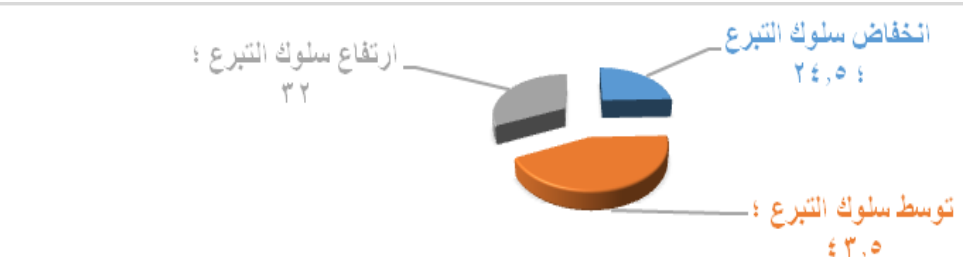

شكل رقم (17) مستويات قيام عينة الدراسة بسلوك التبرع تأثرًا بإعلانات

$$
\text { المؤسسات الخيرية }
$$

يكثنف الثكل السابق عن توسط سلوك تبرع عينة الدر اسة للمؤسسات الخيرية تأثرًا

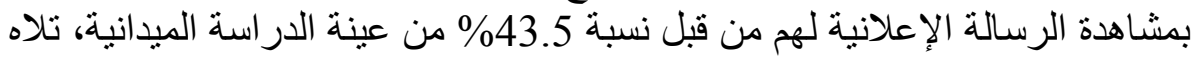

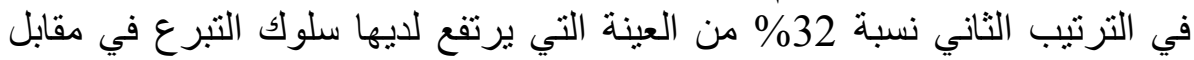

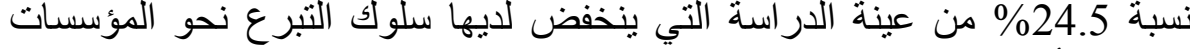
الخيرية تأثرًا بمشاهدة الرسائل الإعلانية.

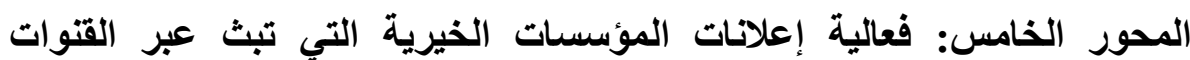

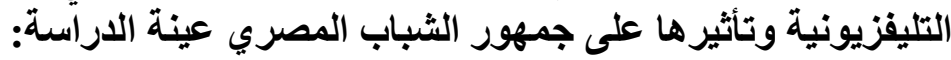

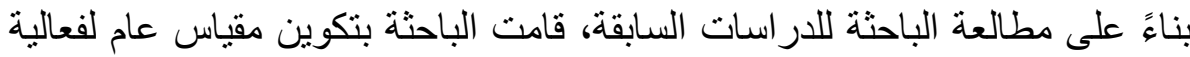

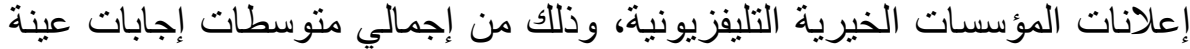

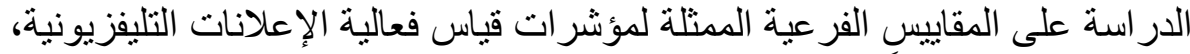

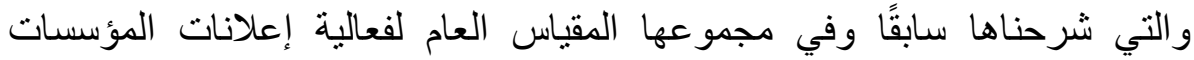
الخيرية التليفزيونية، وذللك على النحو التالي:

جدول رقم (9) يوضتح المقاييس الفرعية التي شكلت المقياس العام لفعالية إعلانات المؤسسات الخيرية الفي الثية

\begin{tabular}{|c|c|c|}
\hline الترتيب & 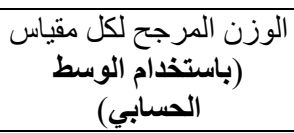 & 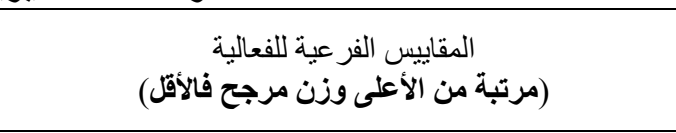 \\
\hline 1 & 58 & مقياس الخبرة المباثرة في التفاعل مع مؤسسات الخيرية \\
\hline 2 & 55.2 & مقياس الاتجاه نحو إعلانات المؤسسات الخيرية \\
\hline 3 & 36.6 & مقياس مصداقية الثخصيات المؤثرة في الرسالة الإعلانية \\
\hline 4 & 30 & مقياس العو امل الدتعلقة بإدارة إعلانات المؤسسات الخيرية \\
\hline 5 & 28.5 & مقياس العو امل المتعلقة بمضمون إعلانات المؤسسات الخيرية \\
\hline 6 & 23.5 & مقياس تذكر عناصر الرسالة الإعلانية للمؤسسات الخيرية \\
\hline
\end{tabular}

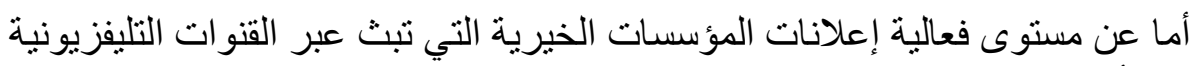
في تأثير ها على جمهور الثباب المصري عينة الثئن الدراسة، فكانت على النحو التالي: 


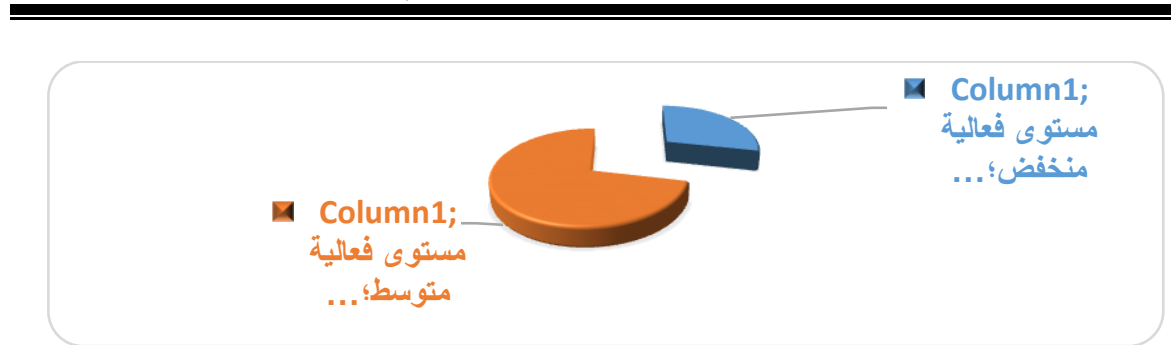

شكل رقم (18) مستويات فعالية إعلانات المؤسسات الخيرية التي تبث عبر القنوات

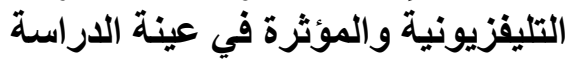

يتضح من الشكل السابق أن فعالية إعلانات المؤسسات الخيرية في تأثيرها على على سلوك التكافل الاجتماعي للثباب المصري عينة الدراسة بشكل عات عام وعبر مؤشر اتها الفرعية الستة كانت متوسطة بنسبة 71.5\% في مقابل الفعالية المنخفض بنسبة 28.5

\section{الجزء الثاني: فروض الدن الداهة الميدانية:}

الفرض الرئيسـي الأول: تـؤثر كثافـة متابعـة إعلانـات المؤسســات الخيريـة بـالقنو ات

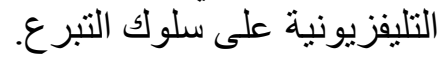

ولمعرفة ذلك تم استخدام أسلوب تحليل الانحدار البسيط، والذي كانت نتائجهه على لـى النحو التالي:

جدول رقم (10) يوضح أثر كثافة التعرض للإعلانات التليفزيونية للمؤسسات

\begin{tabular}{|c|c|c|c|c|c|c|c|c|}
\hline Sig. & $\mathbf{F}$ & \begin{tabular}{|c} 
Adjusted \\
$\mathbf{R}$ \\
Square \\
\end{tabular} & \begin{tabular}{|c}
$\mathbf{R}$ \\
Square
\end{tabular} & $\begin{array}{c}\text { Mean } \\
\text { Square } \\
\end{array}$ & Df & \begin{tabular}{|c|c|} 
Sum of \\
Squares
\end{tabular} & Model & \\
\hline \multirow{3}{*}{0.000} & \multirow{3}{*}{20.982} & \multirow{3}{*}{0.091} & \multirow{3}{*}{0.096} & 7411.107 & 1 & 7411.107 & Regression & \multirow[t]{3}{*}{ سلوك التبرع } \\
\hline & & & & 353.215 & 198 & 69936.657 & Residual & \\
\hline & & & & & 199 & 77347.764 & Total & \\
\hline
\end{tabular}

تبين وجود أثر ذي دلالة إحصائية لكثافة تعرض عينة الدراسة لإعلانات المؤسسات

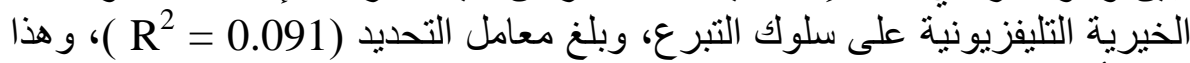

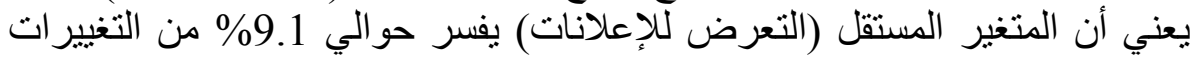

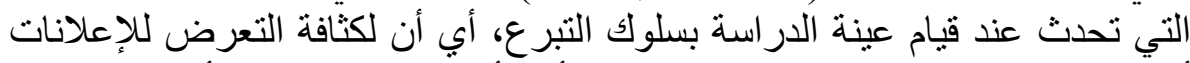

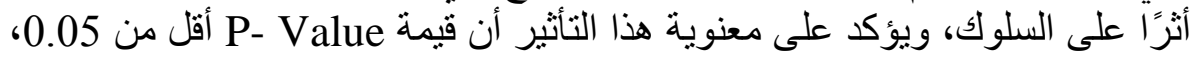
وبلغت قيمنها (0.000)، وكانت قيمة ف (20.982)، وكانت معادلة الانحدار الخطي 


\section{كثافة التعرض لإعلانات المؤسسات الخيرية * 56.428 + (0.158)}

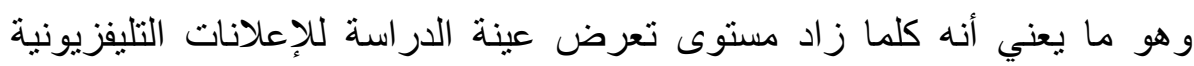

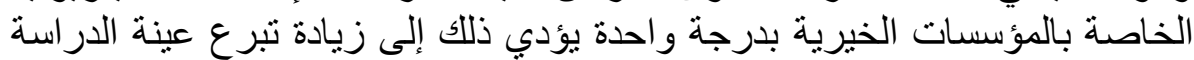

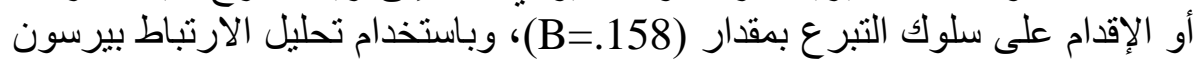

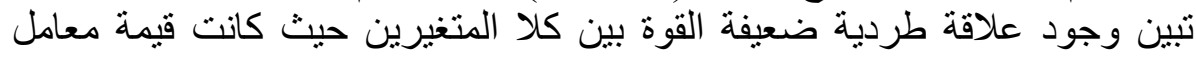
الارثباط (0.310) وذللك عند مستوى معنوية (0.000).

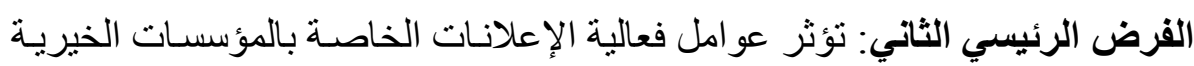

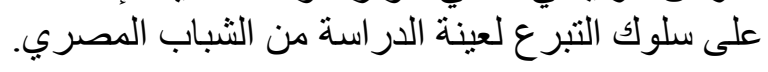

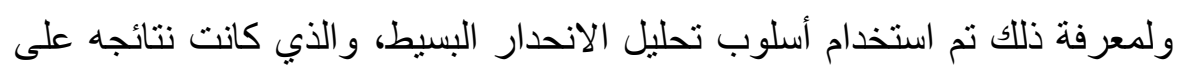
النحو التالي:

جدول رقم (11) يوضح تأثير الفعالية الإعلانية للمؤسسات الخيرية على سلوك التبرع لاى الثباب المصري

\begin{tabular}{|c|c|c|c|c|c|c|c|}
\hline Sig. & $\mathbf{F}$ & R Square & Mean Square & df & Sum of Squares & Model & \\
\hline \multirow{3}{*}{0.000} & \multirow{3}{*}{25.101} & \multirow{3}{*}{0.113} & 8702.238 & 1 & 8702.238 & Regression & \multirow{3}{*}{ سلوك التبرع } \\
\hline & & & 346.695 & 198 & 68645.526 & Residual & \\
\hline & & & & 199 & 77347.764 & Total & \\
\hline
\end{tabular}

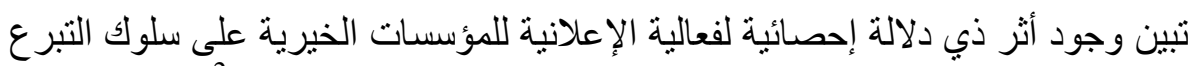

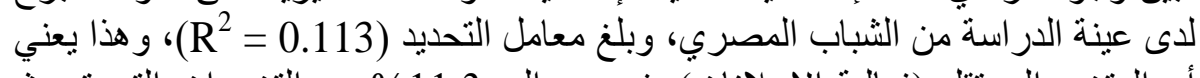

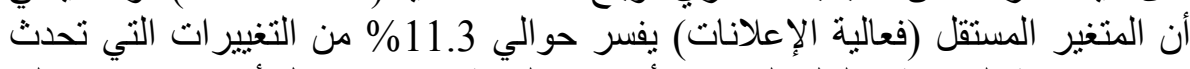

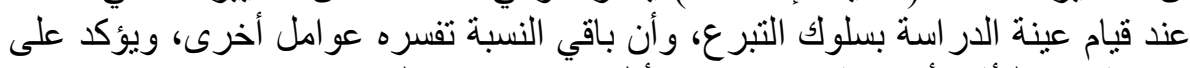

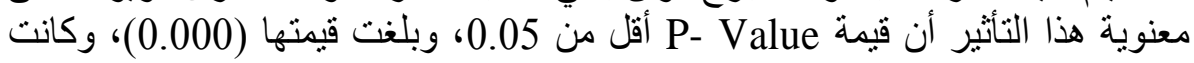
قيمة ف (25.101)، وكانت معادلة الانحدار الخطي البسبط:

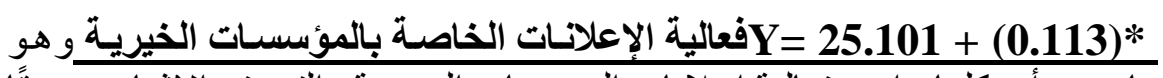

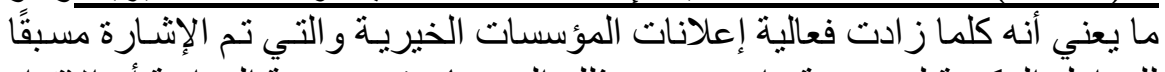

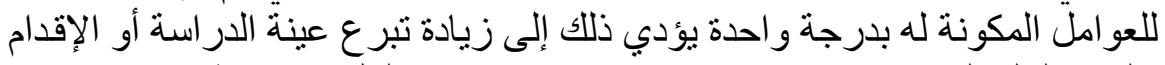

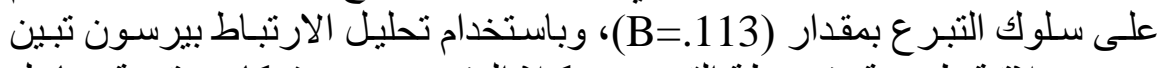

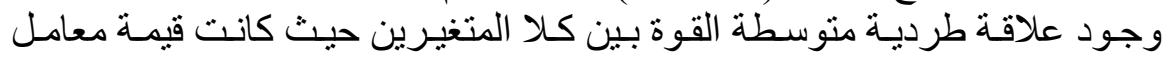
الارتباط (0.335) وذللك عند مستوى معنوية (0.000). 


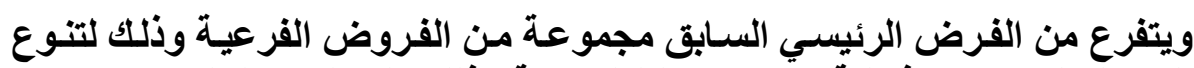

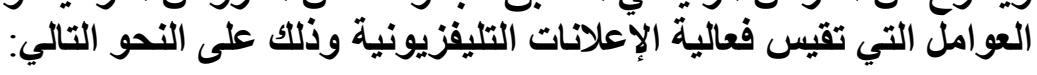

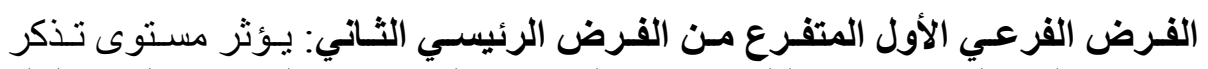

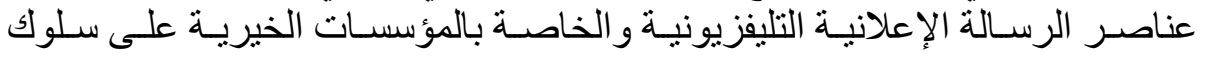
التبر ع لعينة الدر اسة. ولمعرفة ذلك تم استخدام أسلوب تحليل الانحدار المتعدد، والذي كانت نتائجه على لـى النحو التالي:

جدول رقم (12) يوضح أثر تذكر عناصر الرسالة الإعلانية على تحفيز سلوك

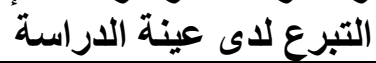

\begin{tabular}{|c|c|c|c|c|c|c|c|c|c|c|}
\hline $\begin{array}{l}\text { SIG } \\
\text { المنتغية } \\
\text { رنغية }\end{array}$ & $\begin{array}{l}\text { قتيمة } \\
\text { Tت }\end{array}$ & $\begin{array}{c}\text { B } \\
\text { الاندارل }\end{array}$ & $\begin{array}{c}\text { (بيتا) } \beta \\
\text { Standard } \\
\text { Coefficient } \\
\text { s }\end{array}$ & المستقيلة & 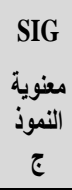 & قيمة F & 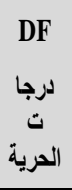 & المربعات & $\begin{array}{c}\mathbf{R}^{2} \\
\text { التصامل } \\
\end{array}$ & التبتفي \\
\hline $\begin{array}{c}0.00 \\
0\end{array}$ & $\begin{array}{c}28.57 \\
0\end{array}$ & $\begin{array}{c}56.00 \\
9\end{array}$ & & $\begin{array}{c}\text { الثابث } \\
\text { Constant) } \\
\text { ( }\end{array}$ & \multirow{3}{*}{0.000} & \multirow{3}{*}{$\begin{array}{c}10.82 \\
8\end{array}$} & 2 & 7660.749 & \multirow{3}{*}{$\begin{array}{c}0.09 \\
9\end{array}$} & \multirow{3}{*}{ سلتبرع } \\
\hline $\begin{array}{c}0.00 \\
1\end{array}$ & 3.440 & 0.178 & 0.238 & التي ورالإعلان & & & 197 & $\begin{array}{c}69687.01 \\
5\end{array}$ & & \\
\hline $\begin{array}{c}0.02 \\
1\end{array}$ & 2.319 & 0.133 & 0.161 & الألونية & & & 199 & $\begin{array}{c}77347.76 \\
4\end{array}$ & & \\
\hline
\end{tabular}

تبين وجود أثر ذي دلالة إحصائية لمتغيرين من مجموعة المتغيرات التي تقيس

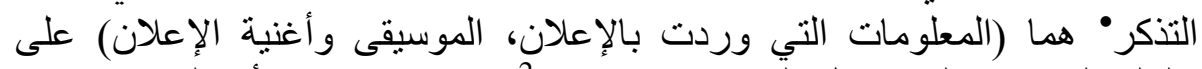

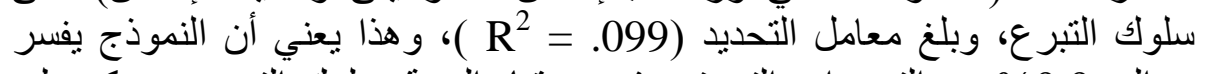

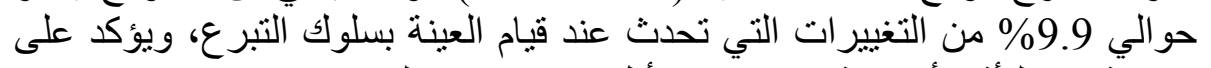

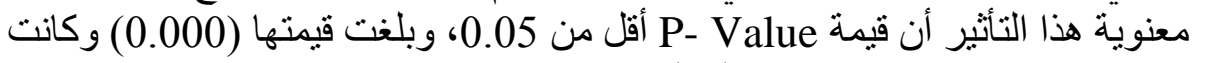
قيمة ف (10.828)، وكانت معادلة النموذج: النير

$\underline{Y=56.009+(0.178) * ~(0.133) * ~}$ الموسيقي والأغنية بالإعلان

ويكثف الجدول السابق عن النقاط التالية:

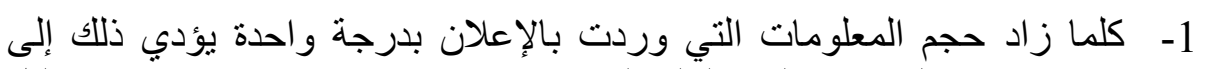
زيادة تحفيز عينة الدراسة على سلوك التبر على بمقدار (B=.178)، وباستخدام تحليل 
الارتباط بيرسون تبين وجود علاقة طردية متوسطة القوة بين كلا المتغيرين حيث (0.273) وذان

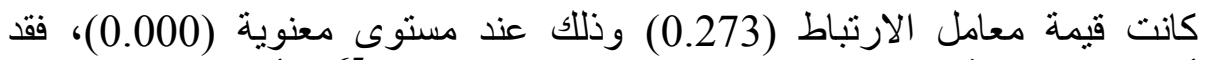

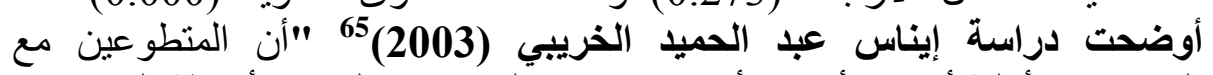

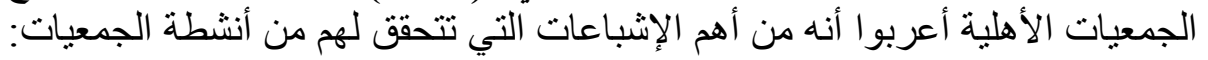

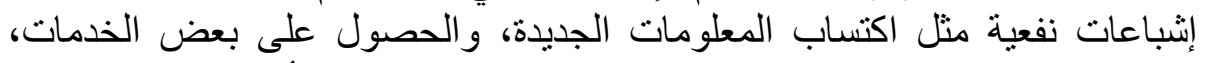

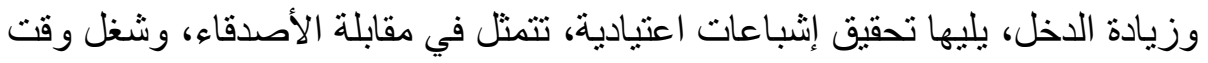

الفراغ.

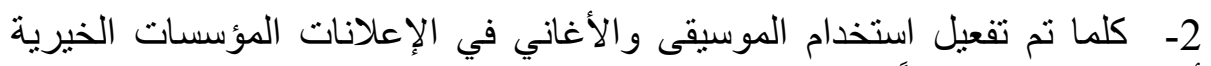

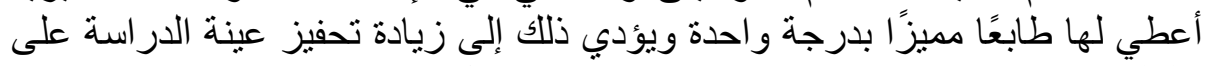

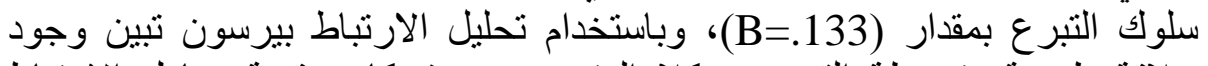

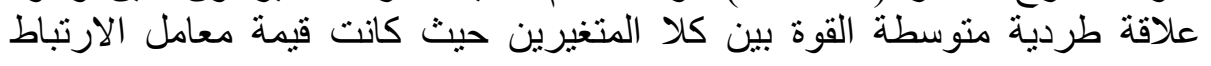
(0.212) وذللك عند مستوى معنوية (0.001).

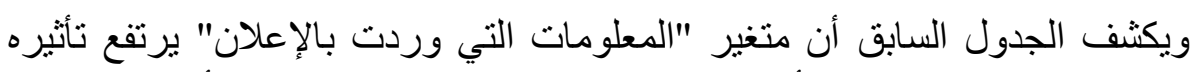

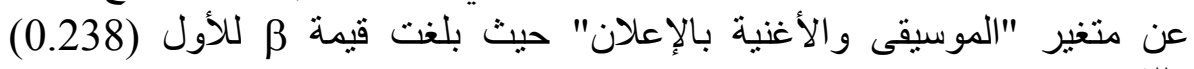
وللثاني (0.161).

واستبعد تحليل الانحدار المتعدد وجود أثر للمتغيرات "فكرة الإعلان، الثخان الثحيات

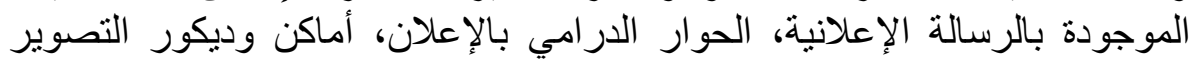

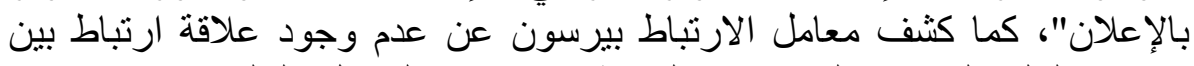

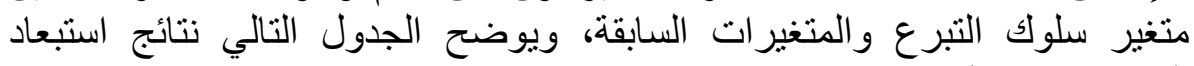

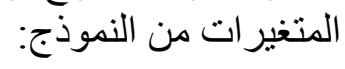

جدول رقم (13) نتائج استبعاد المتغير ات من النموذج باستخدام تحليل الانحدار

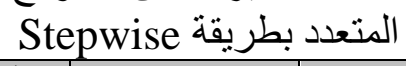

\begin{tabular}{|c|c|c|c|}
\hline معنوية المتغيرSIG & قيمة ت T T T T & معدل الانحدارBB & المتغيرات المستقلة \\
\hline 0.515 & 0.653 & 0.046 & فكرة الإعلان \\
\hline 0.167 & 1.386 & 0.103 & الثخصيات الإعلانية \\
\hline 0.387 & 0.866 & 0.066 & الحوار الدرامي بالإعلان \\
\hline 0.108 & 1.616 & 0.114 & أماكن وديكور التصوير بالإعلان \\
\hline
\end{tabular}

الفرض الفرعي الثاني المتفرع من الفرض الرئيسي الثاني: تؤثر العو امل المحفزة

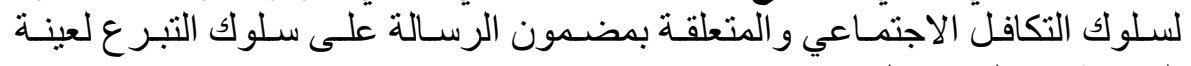
الدر اسة من الثباب المصري التصري.

ولمعرفة ذلك تم استخدام أسلوب تحليل الانحدار المتعدد، والذي كانت نتائجه على النحو التالي: - ne 
جدول رقم (14) يوضح أثر العوامل المحفزة لسلوك التكافل الاجتماعي والمتعلقة

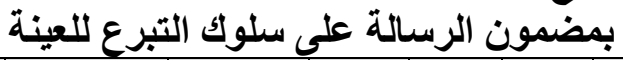

\begin{tabular}{|c|c|c|c|c|c|c|c|c|c|c|}
\hline $\begin{array}{l}\text { SIG } \\
\text { منوية }\end{array}$ & قيمة & معامل & $\begin{array}{c}\text { (بيّا } \beta \\
\text { Standard } \\
\text { Coefficient } \\
\mathbf{s} \\
\end{array}$ & المستفلة & $\begin{array}{l}\text { SIG } \\
\text { النموية } \\
\text { جنوية } \\
\end{array}$ & قيمة & لرجا & المربعات & 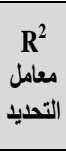 & التنتفيع \\
\hline $\begin{array}{c}0.00 \\
0\end{array}$ & $\begin{array}{c}19.23 \\
9\end{array}$ & $\begin{array}{c}60.04 \\
7\end{array}$ & - & $\begin{array}{c}\text { الثابت } \\
\text { Constant) }\end{array}$ & \multirow{4}{*}{0.000} & \multirow{4}{*}{$\begin{array}{c}7.16 \\
3\end{array}$} & 3 & 7642.692 & \multirow{4}{*}{$\begin{array}{c}0.09 \\
0\end{array}$} & \multirow{4}{*}{ لتبرع } \\
\hline $\begin{array}{c}0.00 \\
5\end{array}$ & 2.853 & 0.140 & 0.195 & قالدارة الأغاني & & & 196 & $\begin{array}{c}69705.07 \\
2\end{array}$ & & \\
\hline $\begin{array}{c}0.02 \\
4\end{array}$ & 2.267 & 0.157 & 0.175 & الإلعانكار & & & \multirow[t]{2}{*}{199} & \multirow{2}{*}{$\begin{array}{c}77347.76 \\
4\end{array}$} & & \\
\hline $\begin{array}{c}0.03 \\
6\end{array}$ & 2.117 & 0.080 & 0.147 & $\begin{array}{c}\text { الالاستمالات } \\
\text { الاستعفية }\end{array}$ & & & & & & \\
\hline
\end{tabular}

تبين وجود أثر ذي دلالة إحصائية لثناث متغير ات من مجموعة المتغير ات التي تقيس

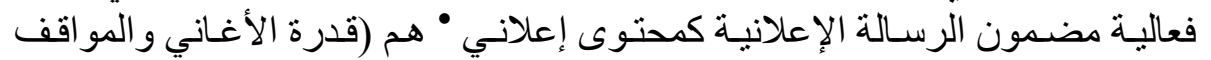

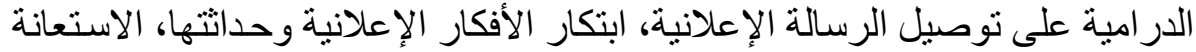

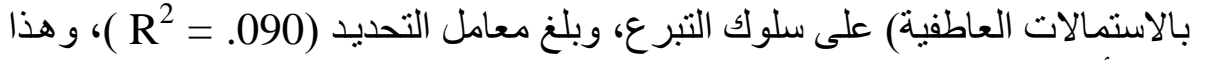

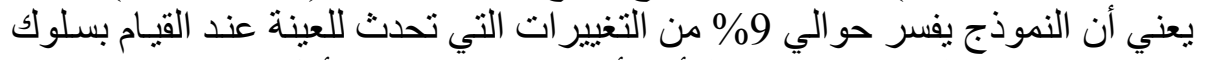

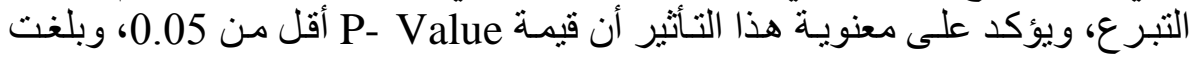

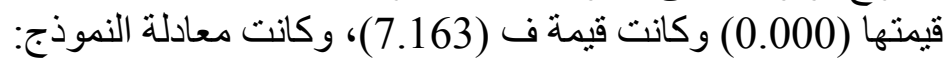

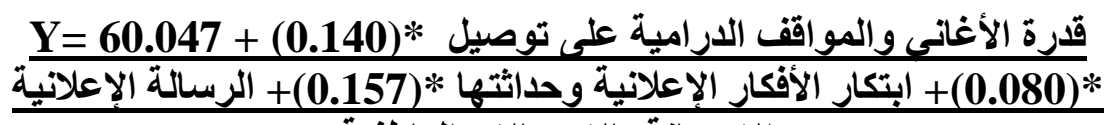

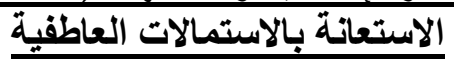

$$
\text { ويكثف الجدول السابق عن النقاط التالية: }
$$

1- كلما زاد توظيف الأغاني و المو اقف الدر امية في توصيل الرسالة الإعلانية بدرجة

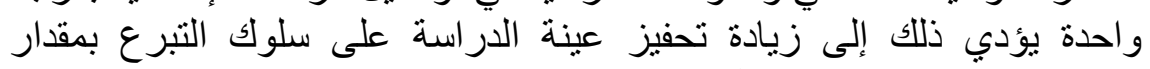

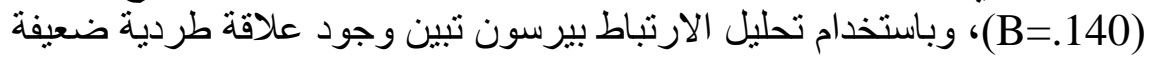

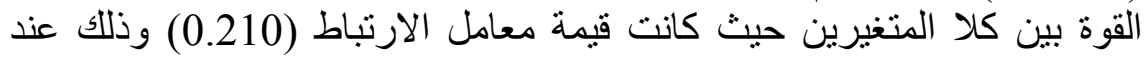

$$
\text { مسنوى معنوية (0.001). }
$$


2- كلما راعت إعلانات المؤسسات الخيرية التجديد والابتكار و التحديث في أفكار ها

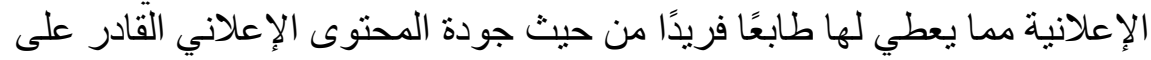

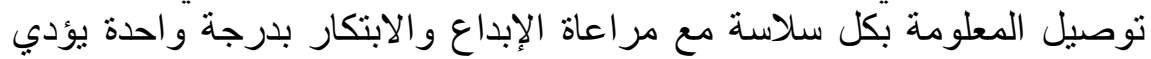

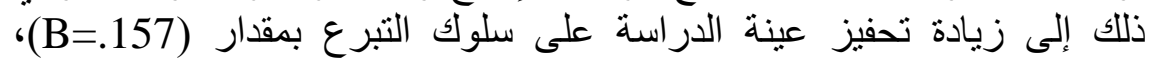

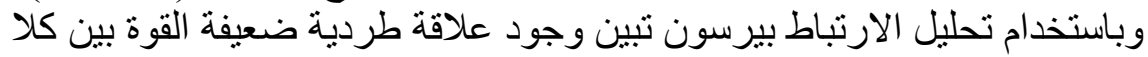
المتغيرين حيث كانت قيمة معامل الارنباط (0.182) وذلك تبن عند مستوى معنوية

3- كلما وظف القائمين على صناعة إعلانات المؤسسات الخيرية الاستمالات

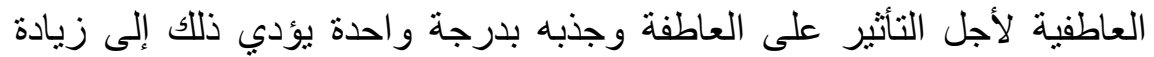

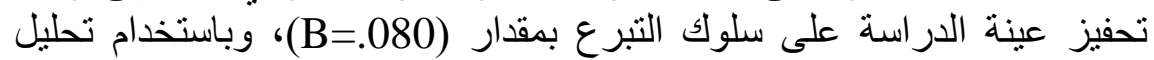

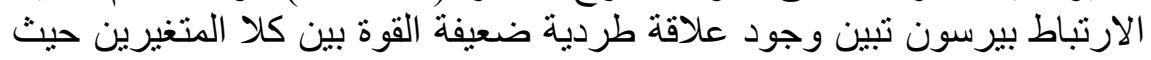

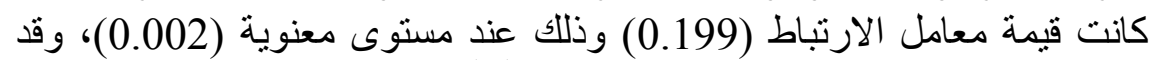

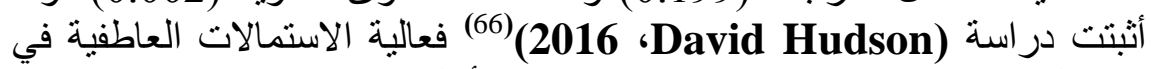
توصيل الرسالة التنموية الهادفة لجمع تبر عات لأجل مو اجهة الفقر.

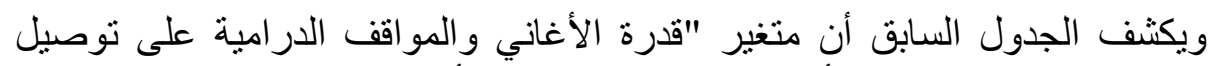

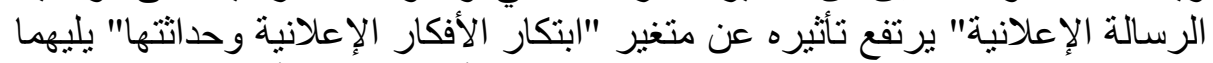

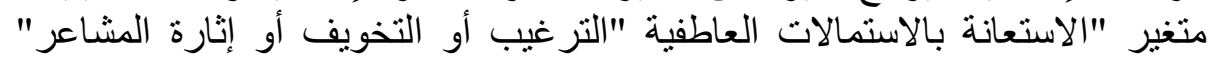

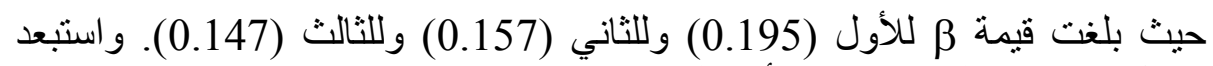

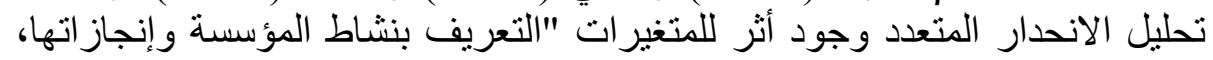

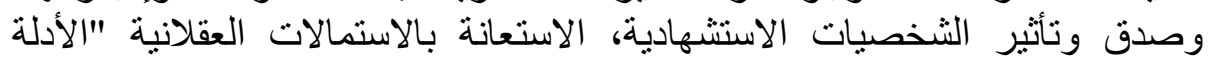

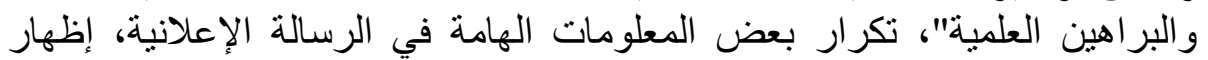

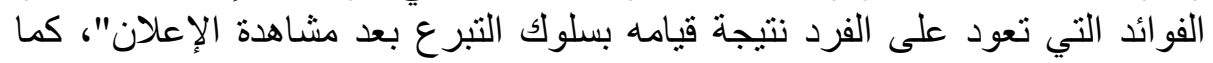

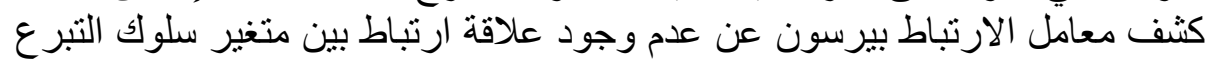

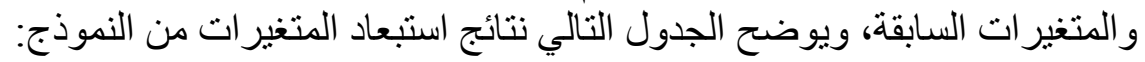
جدول رقم (15) نتائج استبعاد المتغيرات من النموذج باستخدام تحليل الانحدار Stepwise المتعدد بطريقة المونة

\begin{tabular}{|c|c|c|c|}
\hline المتغير SIG & 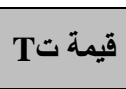 & الانددار B معدل & المتغيرات المستقلة \\
\hline 0.965 & 0.044 & 0.003 & التعريف بنشاط المؤسسة و إنجاز اتها \\
\hline 0.314 & 1.009 & 0.074 & صدق وتأثيّر الثخصيات الاستشههادية \\
\hline 0.094 & 1.681 & 0.116 & الاستعانة بالاستمالات العقلانية (الأدلة و البر اهين) \\
\hline 0.442 & 0.770 & 0.054 & تكرار بعض المعلومات الهامة في الرسالة الإعلانية \\
\hline 0.947 & 0.067 & 0.005 & إظهار الفو الثند التي تعود عثلى الفرد نتيجة قيامه بسلوك الإنعان \\
\hline
\end{tabular}




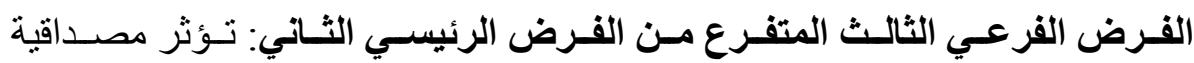

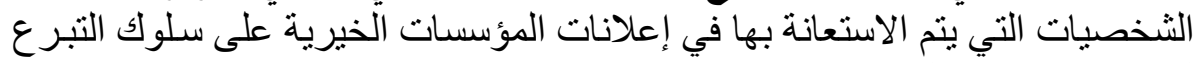

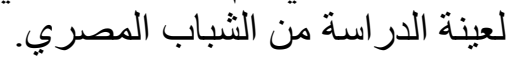

ولمعرفة ذلك نم استخدام أسلوب تحليل الانحدار المتعدد، والذي كانت نتائجه على

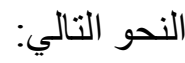

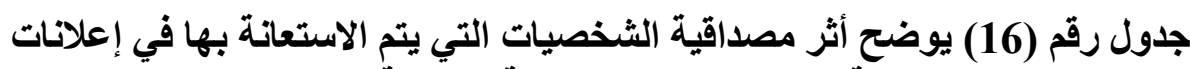

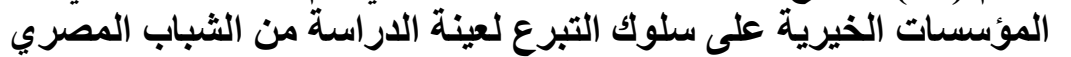

\begin{tabular}{|c|c|c|c|c|c|c|c|c|c|c|}
\hline $\begin{array}{l}\text { SIG } \\
\text { المنتوية } \\
\end{array}$ & قيمة & $\begin{array}{c}\text { B } \\
\text { معامل }\end{array}$ & $\begin{array}{c}\text { (بيّا } \beta \\
\text { Standard } \\
\text { Coefficient } \\
\quad \mathrm{s}\end{array}$ & المستقيلة & $\begin{array}{l}\text { SIG } \\
\text { معنوية } \\
\text { النمون }\end{array}$ & قيمة F & 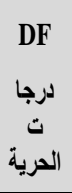 & المربعات & $\begin{array}{l}\mathbf{R}^{2} \\
\text { التعلد } \\
\text { التامل }\end{array}$ & التبانيع \\
\hline $\begin{array}{c}0.00 \\
0\end{array}$ & $\begin{array}{c}27.25 \\
6\end{array}$ & $\begin{array}{c}59.70 \\
6\end{array}$ & - & $\begin{array}{c}\text { الثابث } \\
\text { Constant) } \\
\text { ( }\end{array}$ & \multirow{3}{*}{0.000} & \multirow{3}{*}{$\begin{array}{c}17.08 \\
0\end{array}$} & 2 & $\begin{array}{c}11430.06 \\
6\end{array}$ & \multirow{3}{*}{$\begin{array}{c}0.14 \\
8\end{array}$} & \multirow{3}{*}{ التبرع سلو } \\
\hline $\begin{array}{c}0.00 \\
0\end{array}$ & 5.312 & 0.167 & 0.354 & رجال دين & & & 197 & $\begin{array}{c}65917.69 \\
8 \\
\end{array}$ & & \\
\hline $\begin{array}{c}0.00 \\
1\end{array}$ & 3.245 & 0.135 & 0.216 & رياضيين & & & 199 & 77.47 .764 & & \\
\hline
\end{tabular}

تبين وجود أثر ذي دلالة إحصائية لشخصيتين من مجموعة الثخصيات الاستشهادية

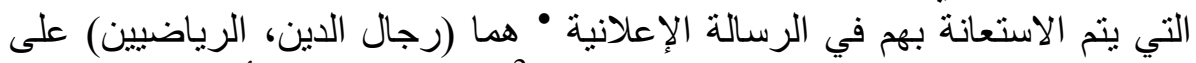

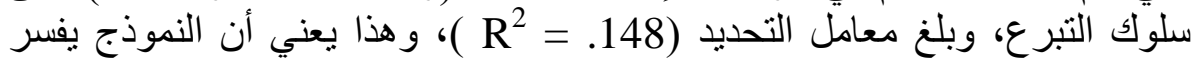

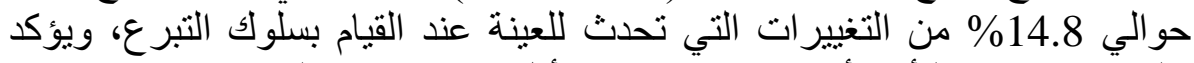

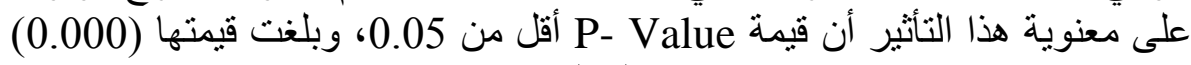
وكانت قيمة ف (17.080)، وكانت معادلة النموذج: فئن

\section{ب= 59.706 + (0.167)* رياضيين * (0.135) + رجال دين}

ويكثف الجدول السابق عن النقاط التالية:

1- كلما تم الاستعانة بشخصية "رجال دين" في الإعلانات التليفزيونية المتعلقة

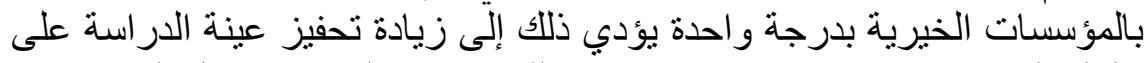

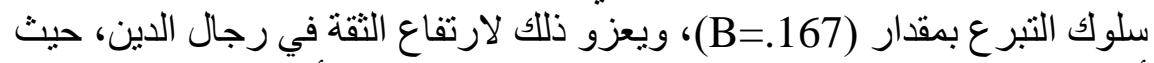

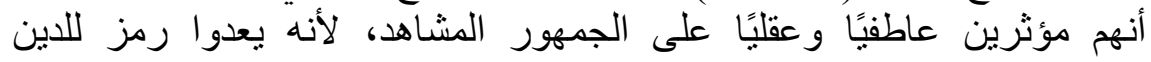

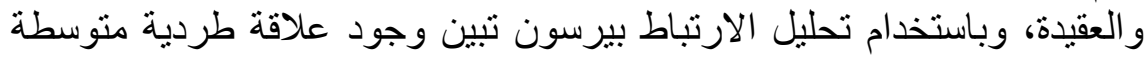

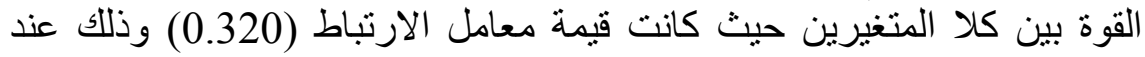

$$
\text { مستوى معنوية (0.000). }
$$


2- كلما تم الاستعانة بشخصية "رياضيين" في الإعلانات التليفزيونية المتعلقة

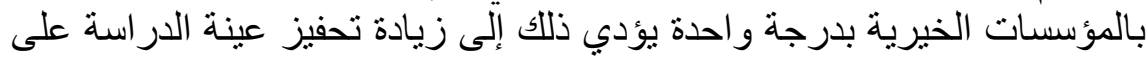

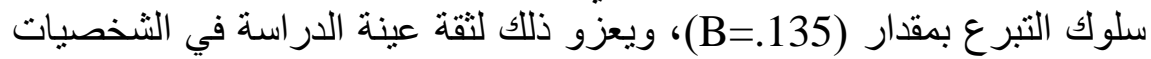

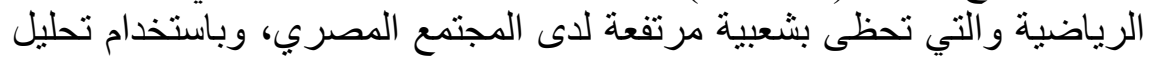

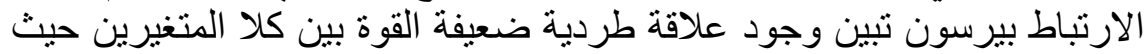

$$
\text { كانت قيمة معامل الارتباط (0.160) وذللك عند مستوى معنوية (0.012). }
$$

ويكثف الجدول السابق أن شخصية "رجال دين" يرتفع تأثيره عن شخصية

$$
\text { "رياضيين" حيث بلغت قيمة م للأول (0.354) وللثناني (0.216). }
$$

واستبعد تحليل الانحدار المتعدد وجود أثر للشخصيات "فنانين، عاملين ولثين

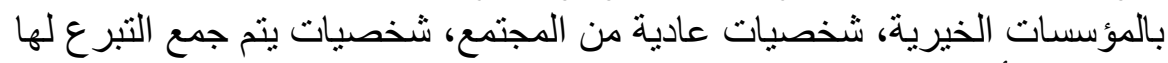

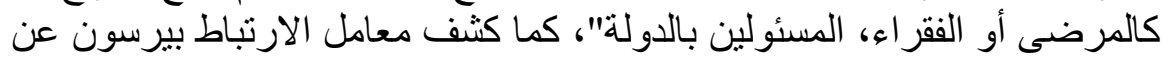

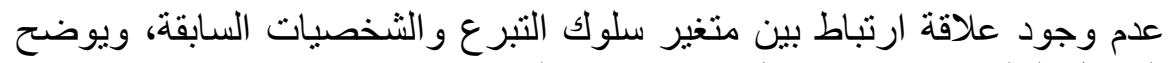

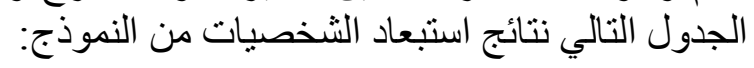

جدول رقم (17) نتائج استبعاد الشخصيات من النموذج باستخدام تحليل الاتحدار

\begin{tabular}{|c|c|c|c|}
\hline المتغير منوية & قيمة ت & الانصدارل معدل & المتغيرات المستقلة \\
\hline 0.718 & 0.361 & 0.031 & فنانين \\
\hline 0.061 & 1.883 & 0.135 & عاملين بالمؤسسات الخيرية \\
\hline 0.239 & 1.180 & 0.084 & شخصيات عادية من المجتمع \\
\hline 0.202 & 1.281 & 0.085 & شخصيات يتم جمع التبر ع لها كالمرضى أو الفقر اء \\
\hline 0.189 & 1.319 & 0.094 & المسئولين بالدولة \\
\hline
\end{tabular}

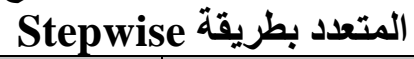

الفرض الفرعي الرابع المتفرع من الفرض الرئيسي الثاني: تؤثر العو امل المتعلقة

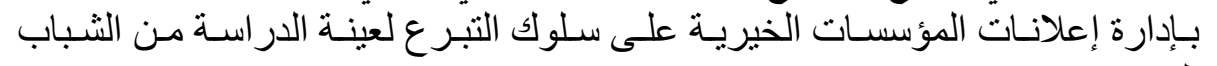

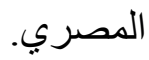


ولمعرفة ذلك تم استخدام أسلوب تحليل الانحدار المتعدد، والذي كانت نتائجه على النحو التالي:

جدول رقم (18) يوضح أثر العوامل المتعلقة بإدارة إعلانات المؤسسات الخيرية على سلوك التبرع لعينة الشباب المصري التصاري

\begin{tabular}{|c|c|c|c|c|c|c|c|c|c|c|}
\hline 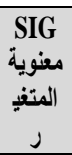 & قّيمة & $\begin{array}{c}\text { B } \\
\text { الاندارل }\end{array}$ & $\begin{array}{c}\text { (بيتّ) } \beta \\
\text { Standard } \\
\text { Coefficient } \\
\text { s }\end{array}$ & المستظقلة & $\begin{array}{c}\text { SIG } \\
\text { النمويةذ } \\
\text { جنوية }\end{array}$ & قيمة F & 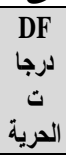 & المربعات & $\begin{array}{c}\mathbf{R}^{2} \\
\text { معامل } \\
\text { التـل } \\
1\end{array}$ & التبابع \\
\hline $\begin{array}{c}0.00 \\
0\end{array}$ & $\begin{array}{c}19.19 \\
2\end{array}$ & $\begin{array}{c}56.26 \\
5\end{array}$ & - & $\begin{array}{c}\text { الثابت } \\
\text { Constant) }\end{array}$ & \multirow{5}{*}{0.000} & \multirow{5}{*}{$\begin{array}{c}14.13 \\
8\end{array}$} & 4 & $\begin{array}{c}17388.89 \\
2\end{array}$ & \multirow{5}{*}{$\begin{array}{c}0.22 \\
5\end{array}$} & \multirow{5}{*}{ سلتوك } \\
\hline $\begin{array}{c}0.00 \\
0\end{array}$ & 4.499 & 0.210 & 0.301 & 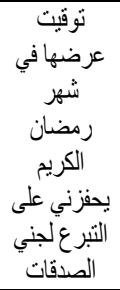 & & & 195 & $\begin{array}{c}59958.87 \\
2\end{array}$ & & \\
\hline $\begin{array}{c}0.00 \\
0\end{array}$ & 3.811 & 0.184 & 0.268 & الالإعلانات المتؤة بذات & & & \multirow{3}{*}{199} & \multirow{3}{*}{$\begin{array}{c}77347.76 \\
4\end{array}$} & & \\
\hline $\begin{array}{c}0.00 \\
6\end{array}$ & 2.755 & 0.129 & 0.183 & 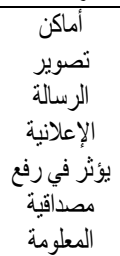 & & & & & & \\
\hline $\begin{array}{c}0.00 \\
9\end{array}$ & 2.656 & 0.114 & 0.188 & 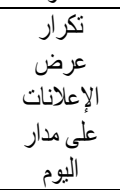 & & & & & & \\
\hline
\end{tabular}

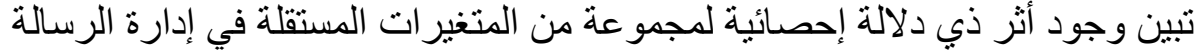

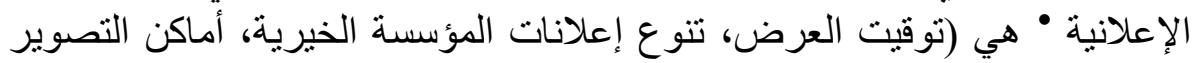

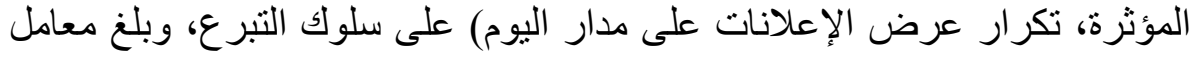


التحديد (225. = R ) )، و هذا يعني أن النموذج يفسر حوالي 22.5\% من التغييرات

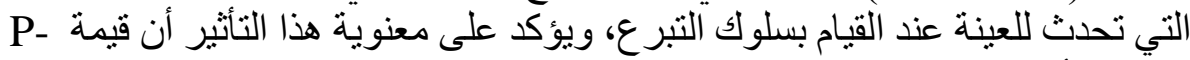

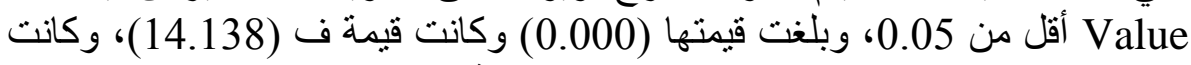
معادلة النموذج:

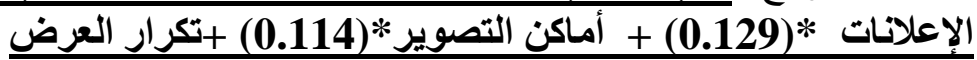
ويكثف الجدول السابق عن النقاط التالية:

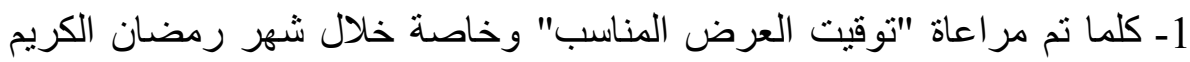

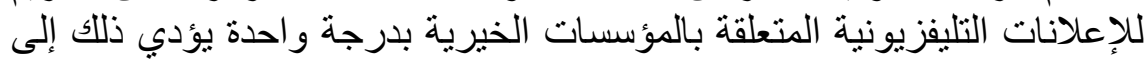

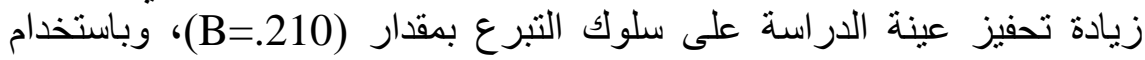
تحليل الارتباط بيرسون تبين وجود علاقة طالة طردية منوسطة القوة بين كلا

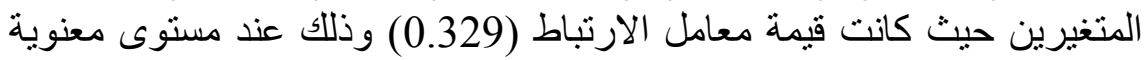

2- كلما تم تنويع الرسائل الإعلانية التليفزيونية المتعلقة بذات المؤسسة الخيرية أي

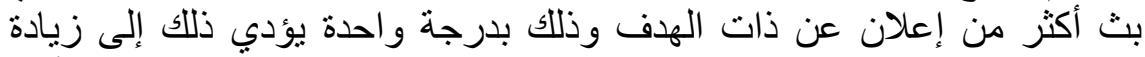

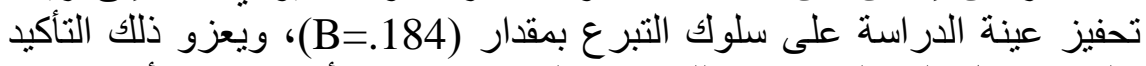

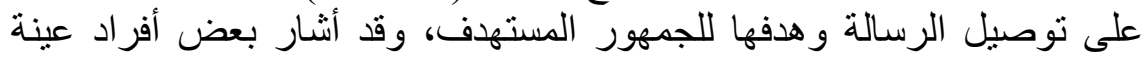

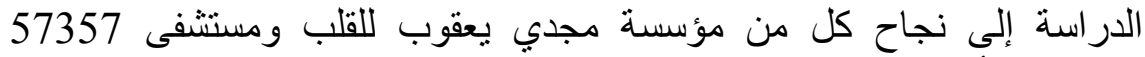

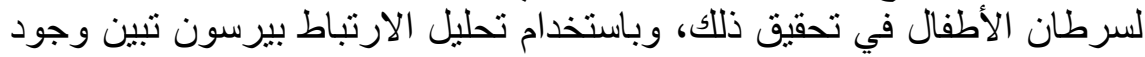

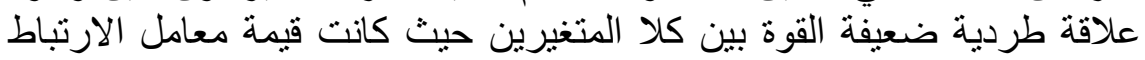
(0.283) وذللك عند مستوى معنوية (0.000).

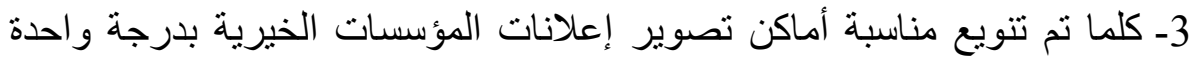

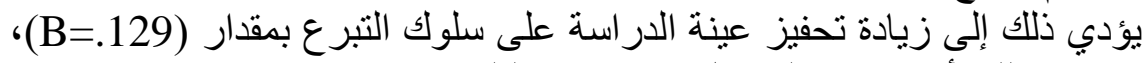

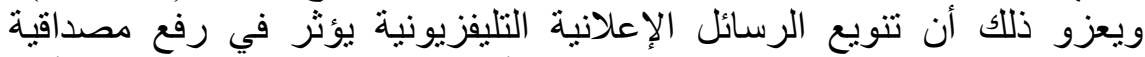

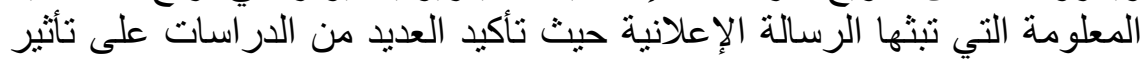

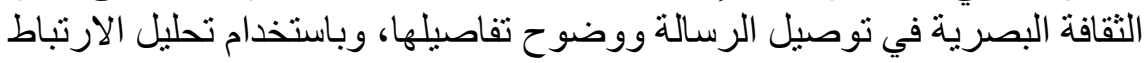

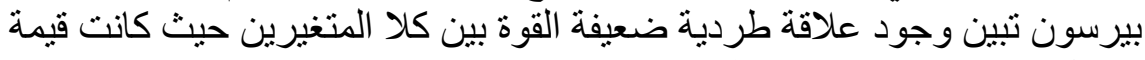
معامل الارتباط (0.295) وذللك عند مستوى معنوية (0.000).

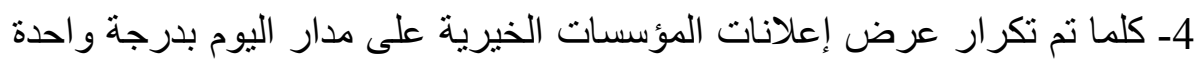

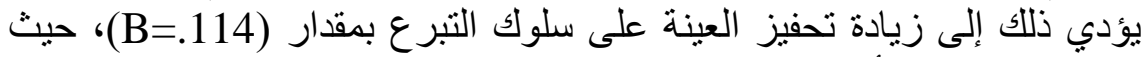

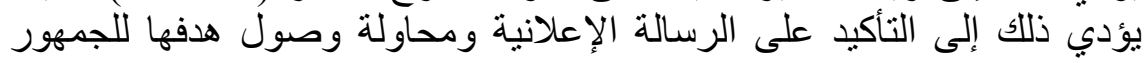

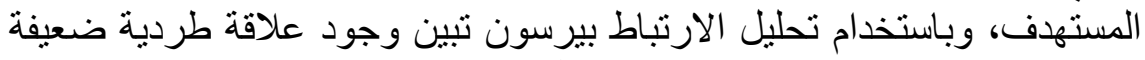

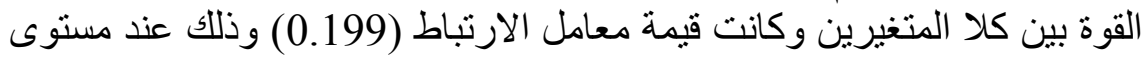

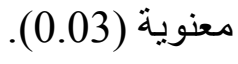


ويكثف الجدول السابق أن متغير "توقيت عرض الإعلانات في شهر رمضان

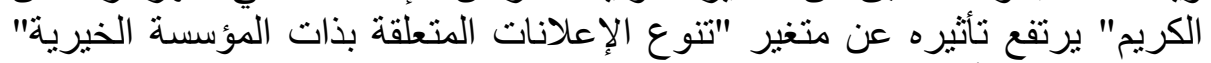

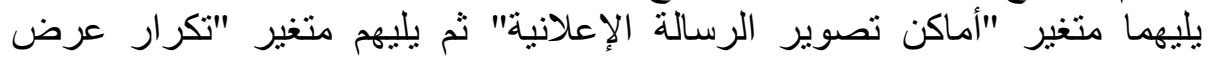
الإعلانات" حيث بلغت قيمة م للأول (0.301) وللثاني (0.268) وللثالث (0.188) وللابع (0.183).

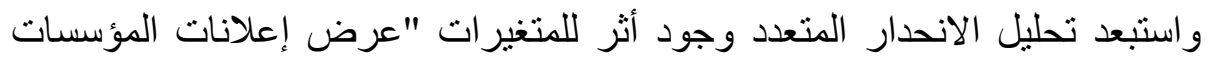

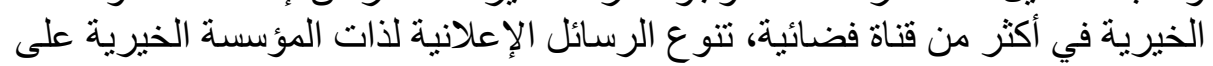

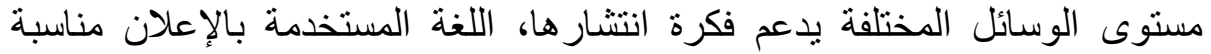

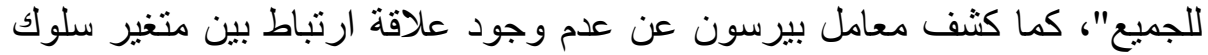

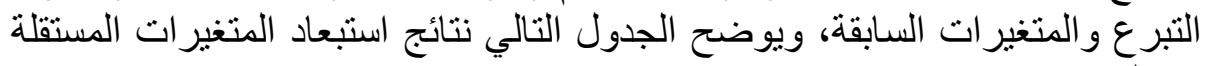

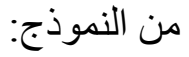

جدول رقم (19) نتائج استبعاد المتغيرات من النموذج باستخدام تحليل الاتحدار

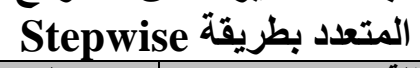

\begin{tabular}{|c|c|c|c|}
\hline المتغيرSIG & قيمة ت T & الانعدار B معل & المتغيرات المستقلة \\
\hline 0.063 & 1.868 & 0.134 & عرض إعلانات المؤسسات الخيرية في أكثر من قناة \\
\hline 0.860 & 0.176 & 0.013 & 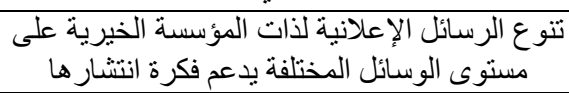 \\
\hline 0.348 & 0.940 & 0.067 & اللغة المستخدمة بالإعلان مناسبة للجميع \\
\hline
\end{tabular}

الفرض الفرعي الخامس المتفرع من الفرض الرئيسي الثاني: تؤثر العو امل المتعلقة

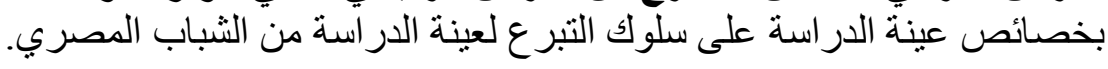

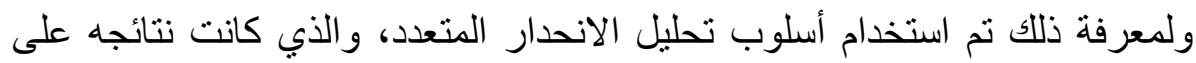
النحو التالي:

جدول رقم (20) يوضح أثر العوامل المتعلقة بخصائص عينة الدراسة على سلوك

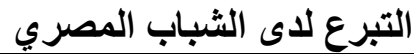

\begin{tabular}{|c|c|c|c|c|c|c|c|c|c|c|}
\hline منتوية & قتيمة & 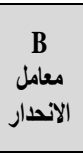 & $\begin{array}{c}\text { (بيتا } \beta \\
\beta \\
\text { Standard } \\
\text { Coefficient } \\
s\end{array}$ & المستقلة & $\begin{array}{l}\text { SIG } \\
\text { النموية } \\
\text { منوذ } \\
\end{array}$ & قيمة F & لرجا & المربعات & $\begin{array}{c}R^{2} \\
\text { معامل }\end{array}$ & التنابع \\
\hline $\begin{array}{c}0.00 \\
0\end{array}$ & $\begin{array}{c}8.71 \\
2\end{array}$ & $\begin{array}{c}33.92 \\
7\end{array}$ & - & $\begin{array}{c}\text { الثابت } \\
\text { Constant) }\end{array}$ & \multirow{3}{*}{0.000} & \multirow{3}{*}{$\begin{array}{c}17.96 \\
2\end{array}$} & 1 & 6433.174 & \multirow{3}{*}{$\begin{array}{c}0.08 \\
3\end{array}$} & \multirow{3}{*}{ سلتوك } \\
\hline \multirow{2}{*}{$\begin{array}{c}0.00 \\
0\end{array}$} & \multirow{2}{*}{$\begin{array}{c}4.23 \\
8\end{array}$} & \multirow{2}{*}{8.136} & \multirow{2}{*}{0.288} & \multirow{2}{*}{ السن } & & & 198 & $\begin{array}{c}70914.59 \\
0\end{array}$ & & \\
\hline & & & & & & & 199 & $\begin{array}{c}77347.76 \\
4\end{array}$ & & \\
\hline
\end{tabular}


تبين وجود أثر ذي دلالة إحصائية لمتغير السن فقط من بين المتغير ات الخاصة بعينة

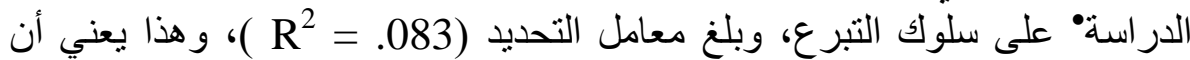

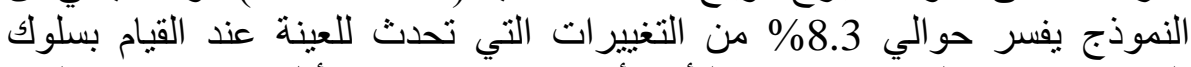
التبرع، ويؤكد على معنوية هذا التأثثر أن قيمة P- Value قيمتها (0.000) وكانت قيمة ف (17.962)، وكانت معادلة النموذج:

\section{$\underline{Y=33.927+(0.8 .136) * 2 ~ ا ل م ر ح ل ة ~ ا ل ع م ر ي ة ~}$}

ويكثف الجدول السابق عن النقاط التالية:

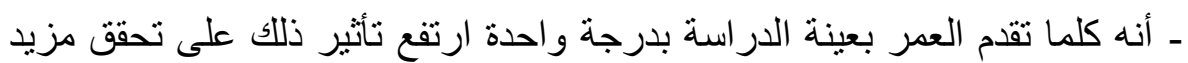

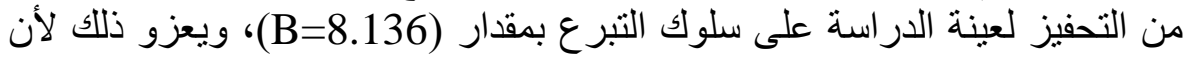

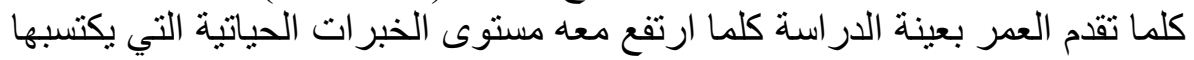

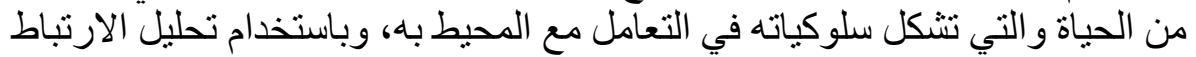
بيرسون تبين وجود علاقة طردية ضعيفة القوة بين كلا المتغيرين حيث كانت التيات قيمة معامل الارنباط (0.288) وذلك عند مستوى معنوية (0.000).

واستبعد تحليل الانحدار المتعدد وجود أثر لباقي المتغيرات المتعلقة بخصائص عينة

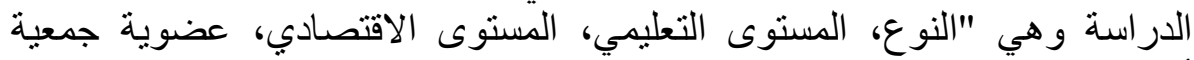

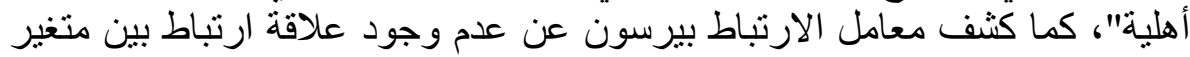

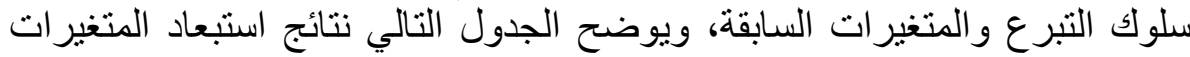

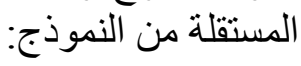

جدول رقم (21) نتائج استبعاد المتغيرات من النموذج باستخدام تحليل الانحدار

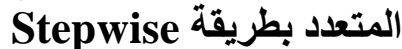

\begin{tabular}{|c|c|c|c|}
\hline المتغير معنوية & قيمة ت T T & Bمدل الاتحدار Bم & المتغيرات المستقلة \\
\hline 0.121 & 1.556 & 0.107 & 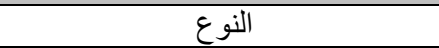 \\
\hline 0.257 & 1.136 & 0.078 & المستوى التعليمي \\
\hline 0.537 & 0.619 & 0.044 & المستوى الاقتصادي \\
\hline 0.265 & 1.118 & 0.077 & عضوية جمعية أهلية \\
\hline 0.496 & 0.683 & 0.047 & خبرة التعامل المباشر مع مؤسسة خيرية \\
\hline
\end{tabular}

الفرض الفرعي السادس المتفرع من الفرض الرئيسي الثاني: تؤُثر اتجاهـات عينة

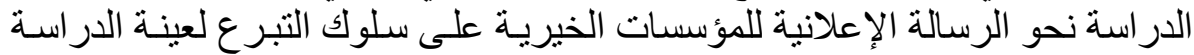
من الثباب المصري.

ولمعرفة ذلك تم استخدام أسلوب تحليل الانحدار البسيط، والذي كانت نتائجه على النحو التالي: - ne 
جدول رقم (22) يوضح تأثير اتجاهات عينة الدراسة نحو الرسالة الإعلانية للمؤسسات الخيرية على سلوك التبرع للشباب المصري التهري

\begin{tabular}{|c|c|c|c|c|c|c|c|}
\hline Sig. & F & $\begin{array}{c}\text { R } \\
\text { Square }\end{array}$ & $\begin{array}{c}\text { Mean } \\
\text { Square }\end{array}$ & df & $\begin{array}{c}\text { Sum of } \\
\text { Squares }\end{array}$ & Model & \\
\hline \multirow{2}{*}{0.000} & \multirow{2}{*}{9.512} & 0.285 & 289.590 & 191 & 55311.679 & Residual & \multirow{2}{*}{ E } \\
\cline { 4 - 7 } & & & 2754.511 & 8 & 22036.085 & Regression & \\
\cline { 4 - 6 } & & & 199 & 77347.764 & Total & \\
\hline
\end{tabular}

تبين وجود أثر ذي دلالة إحصائية لاتجاهات عينة الدراسة نحو إعلانات المؤسسات

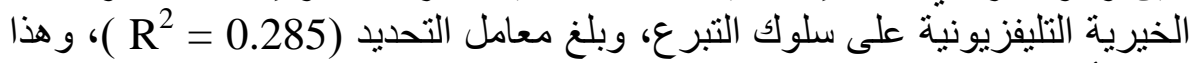

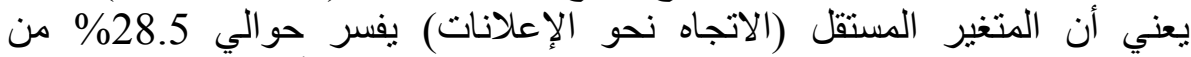

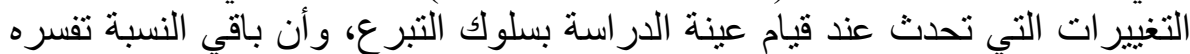
عوامل أخرى، ويؤكد على معنوية هذا التأثير أن قيمة

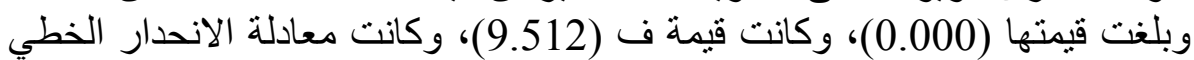

\section{الاتجاه نحو إعلانات المؤسسات الخيرية *}

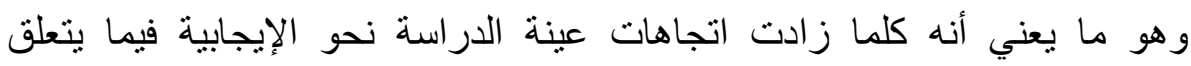

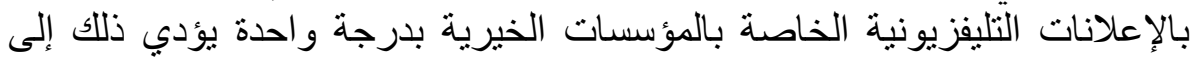

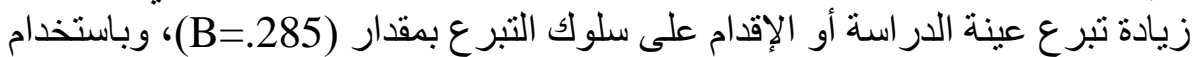
تحليل الارنباط بيرسون تبين وجود الإند علاقة طردية منوسطة القوة بين كلا المتغيرين

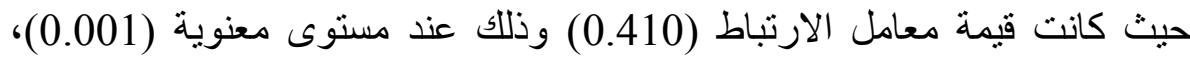
و هي النتيجة التي تتفق مع ما توصلت لهاته دراسة حسن الأن نيازي الصيفي أبو العلا

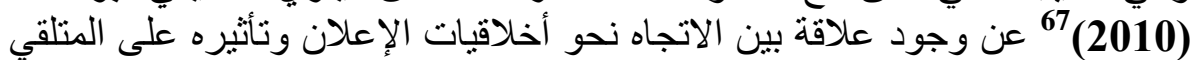

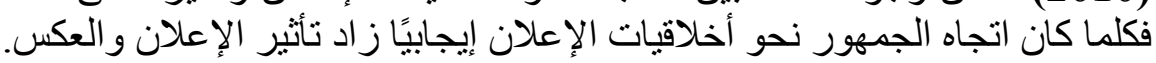

\section{النتائج العامة للاراسة:}

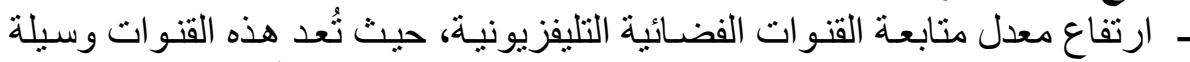

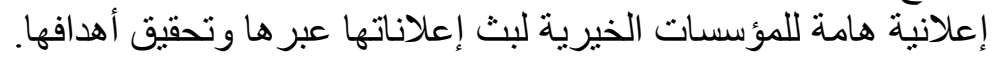

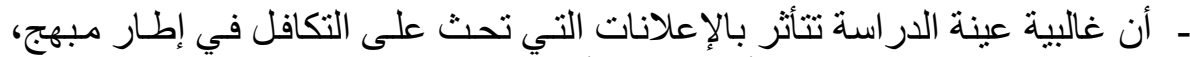

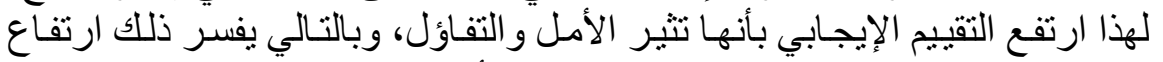

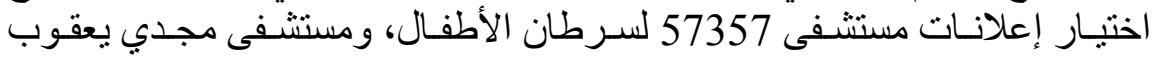

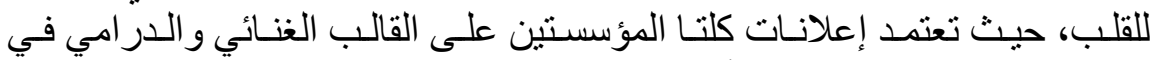

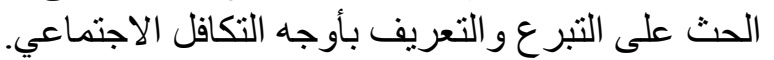

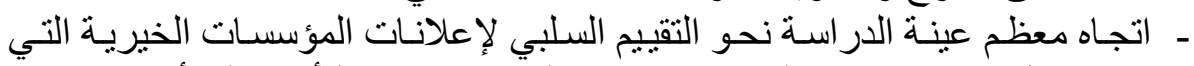
تبث خلال شهر رمضان الكريم، فجاء في المقدمة ارتفاع التأكيد على أنها "تتصف التصات 
بالابتز ازيــة و أقـرب للتســول"، تـلاه فـي وصـفهـا بأنهـا "تنتهــك حقـوق الإنســان وكر امته".

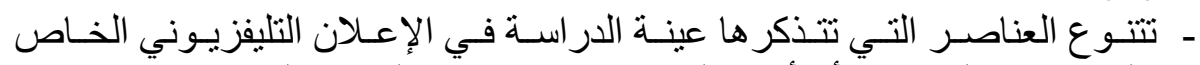

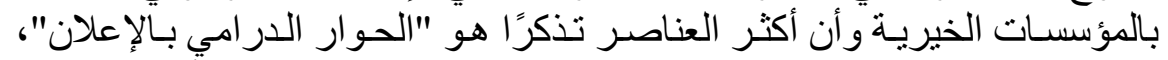

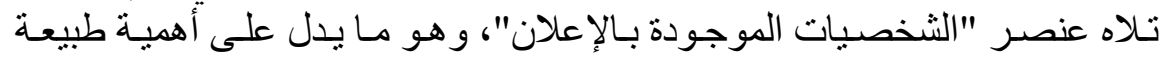

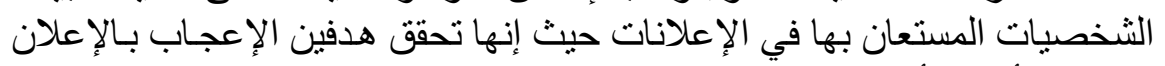

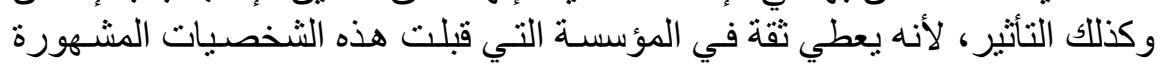

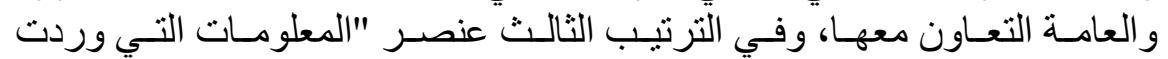

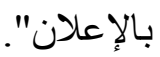

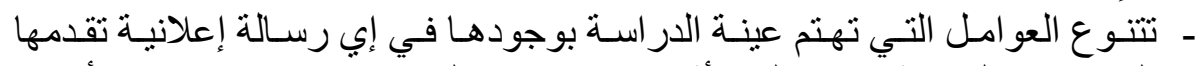

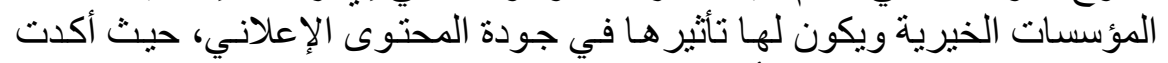

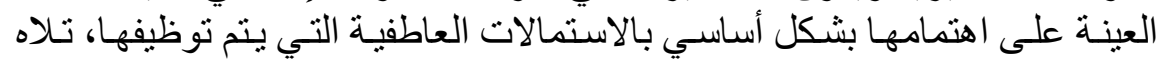

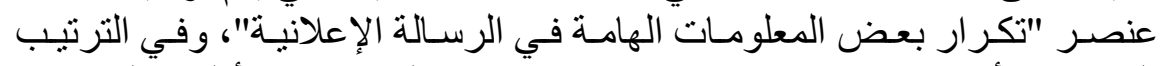

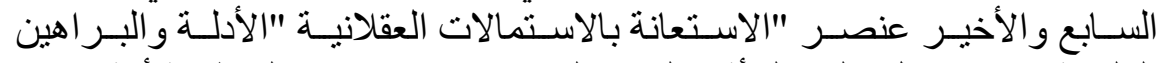

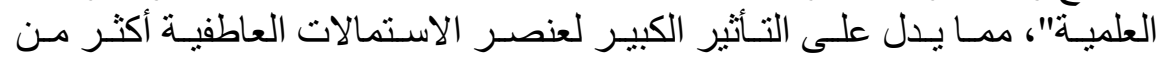

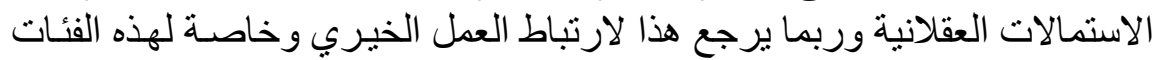

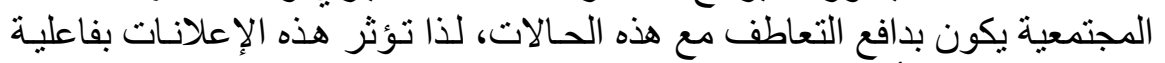

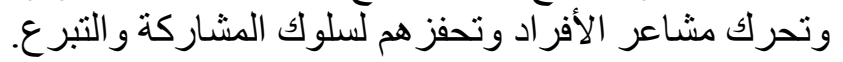

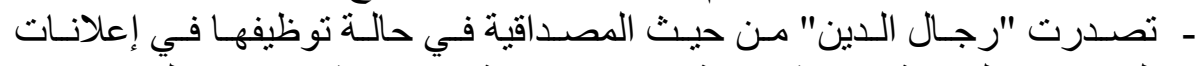

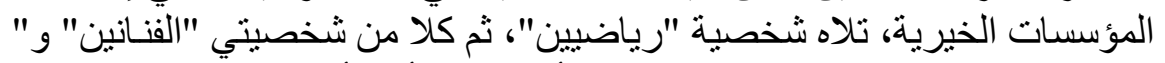

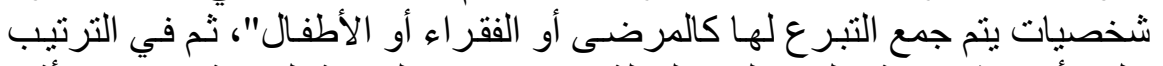

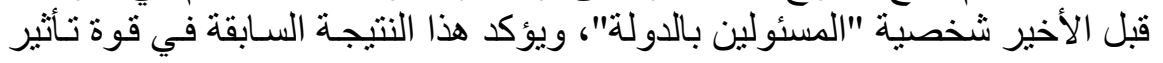

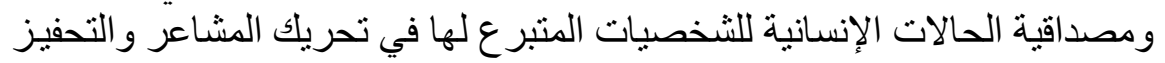
على سلوك التبرع.

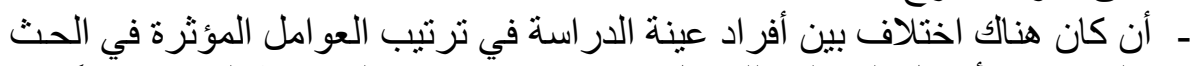

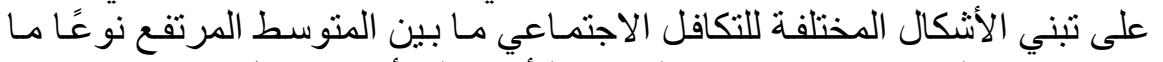

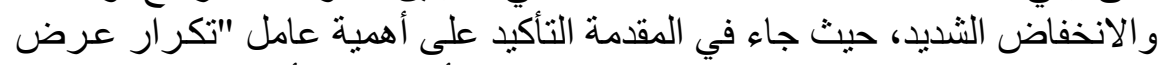

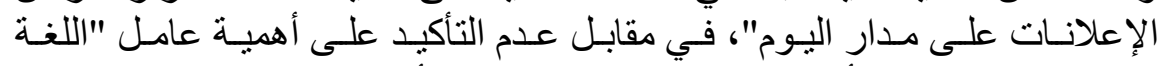

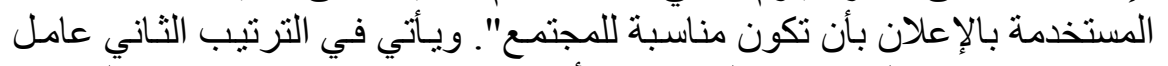

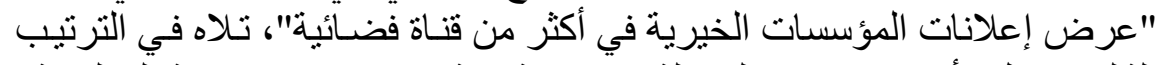

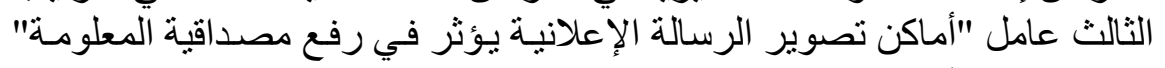

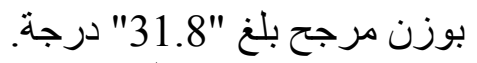

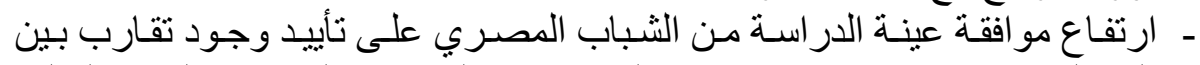

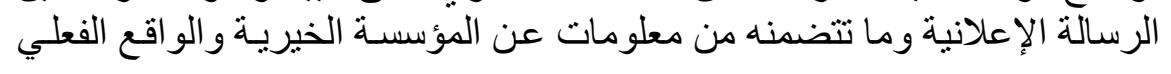




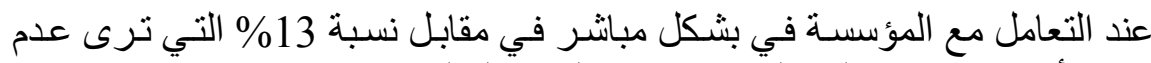

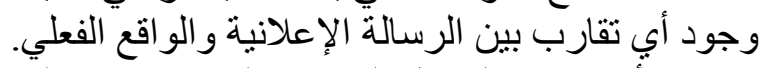

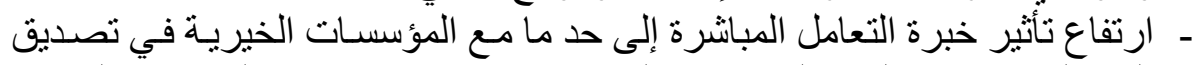

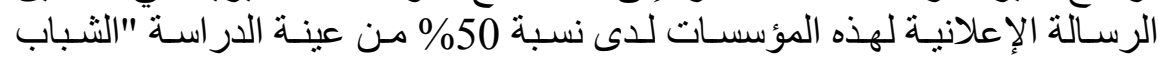

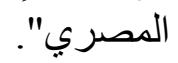

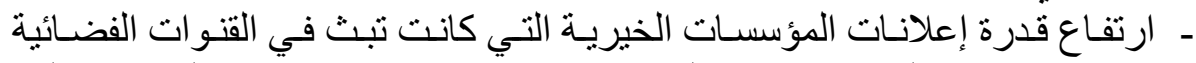

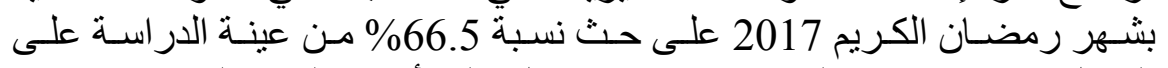

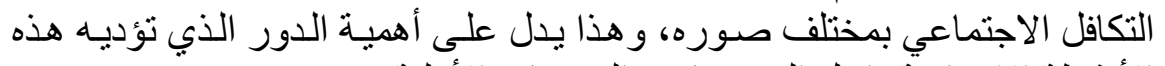

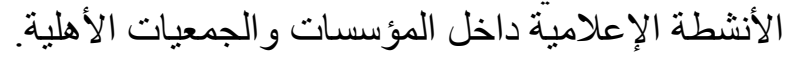

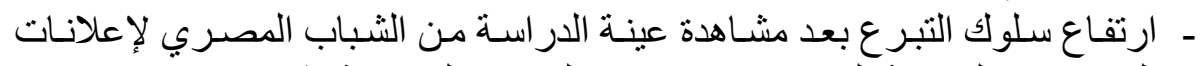

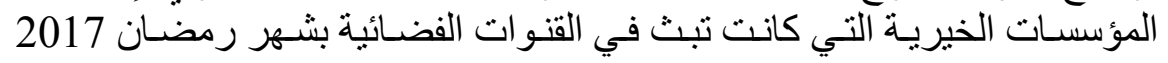

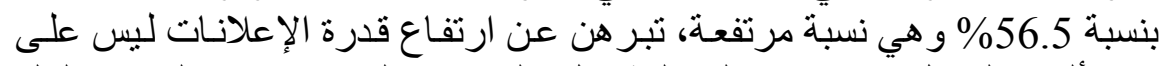

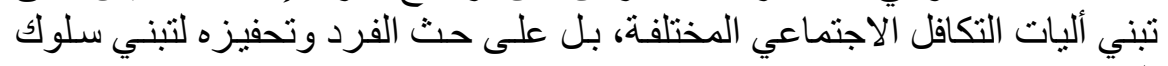
التبرع.

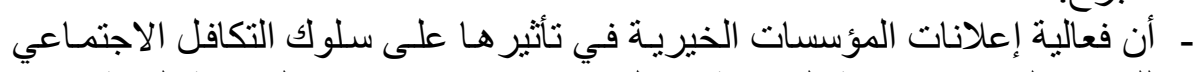

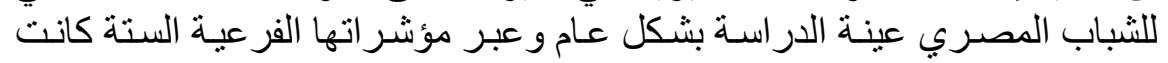

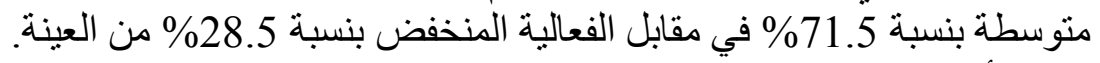

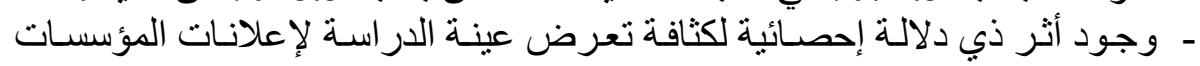

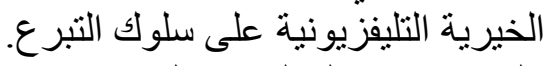

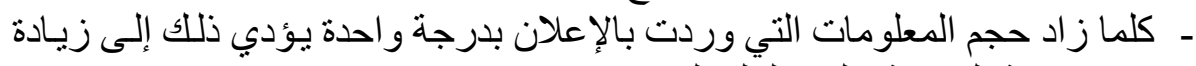

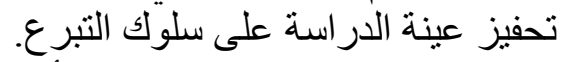

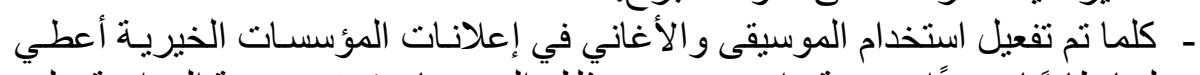

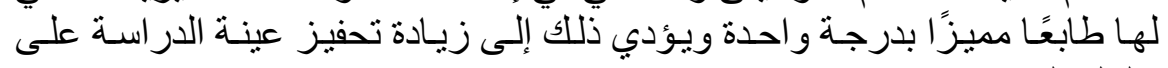

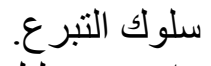

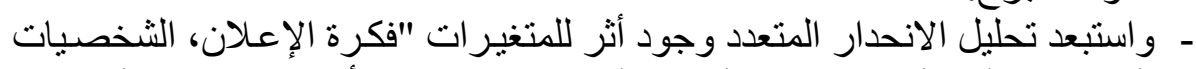

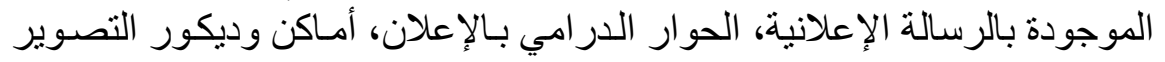

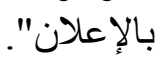

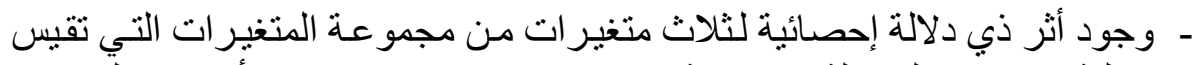

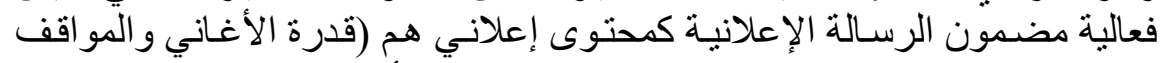

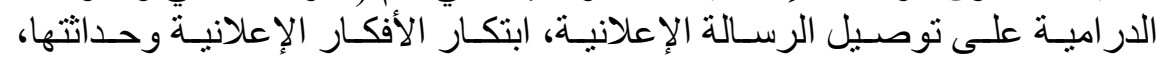

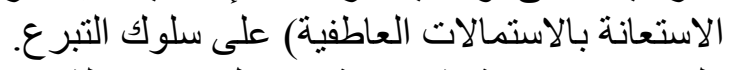

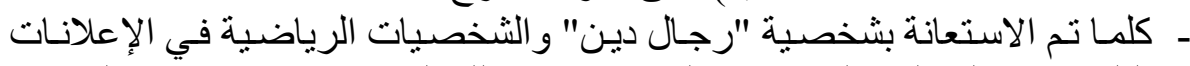

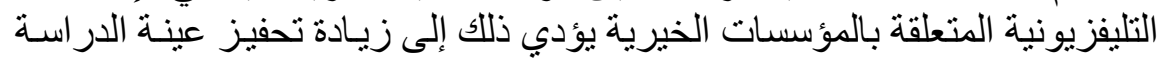
على سلوك التبرع. 


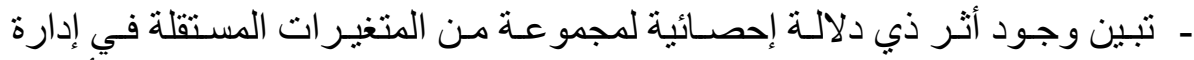

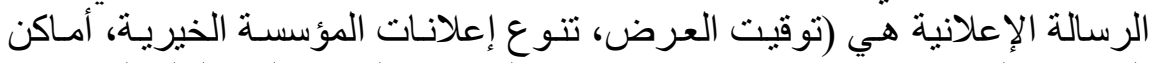

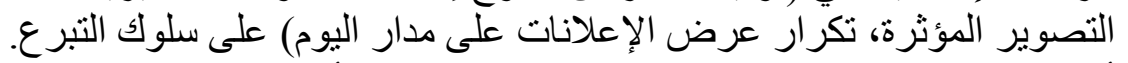

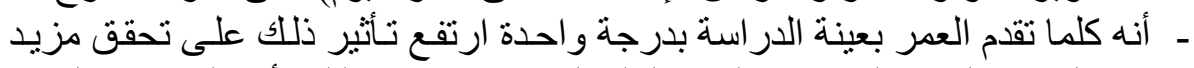

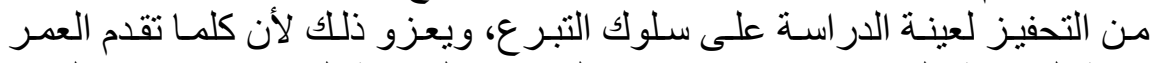

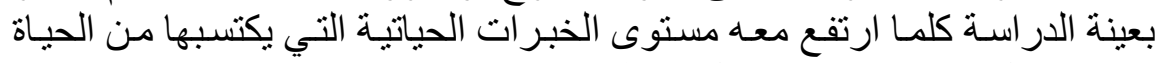

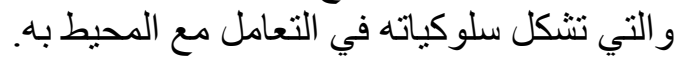

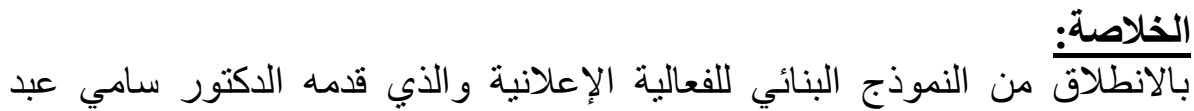

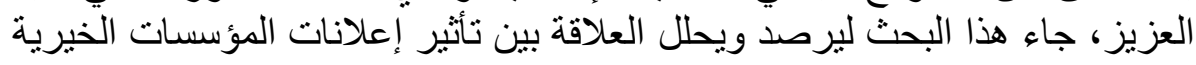

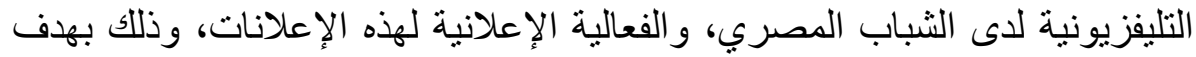

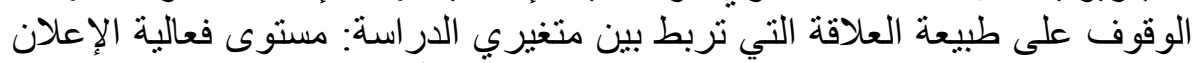

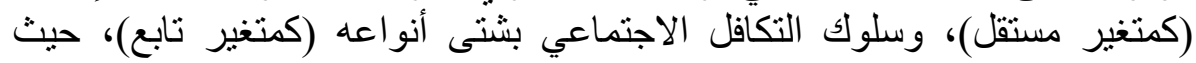
تستهدف الدراسة تقديم نموذج

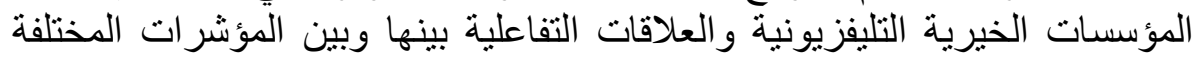

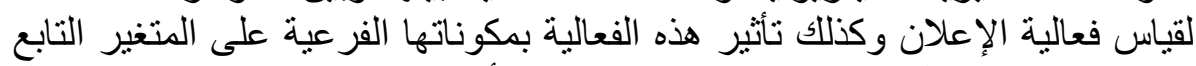

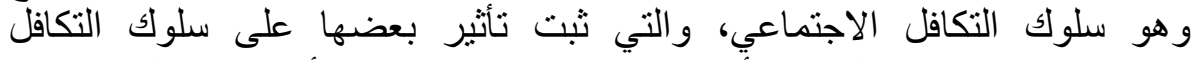

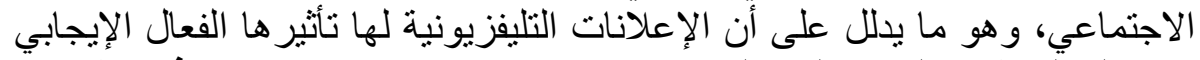

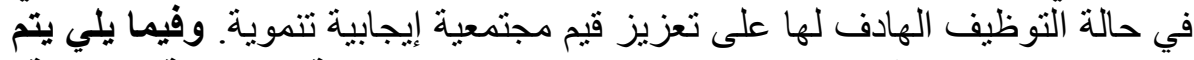

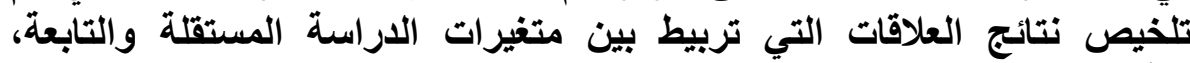

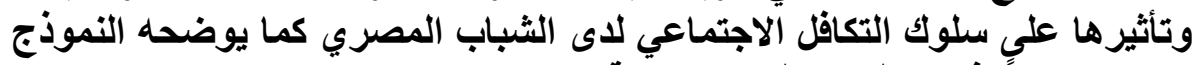
المقترح سابقًا في الإطار النظري للار الأئة:

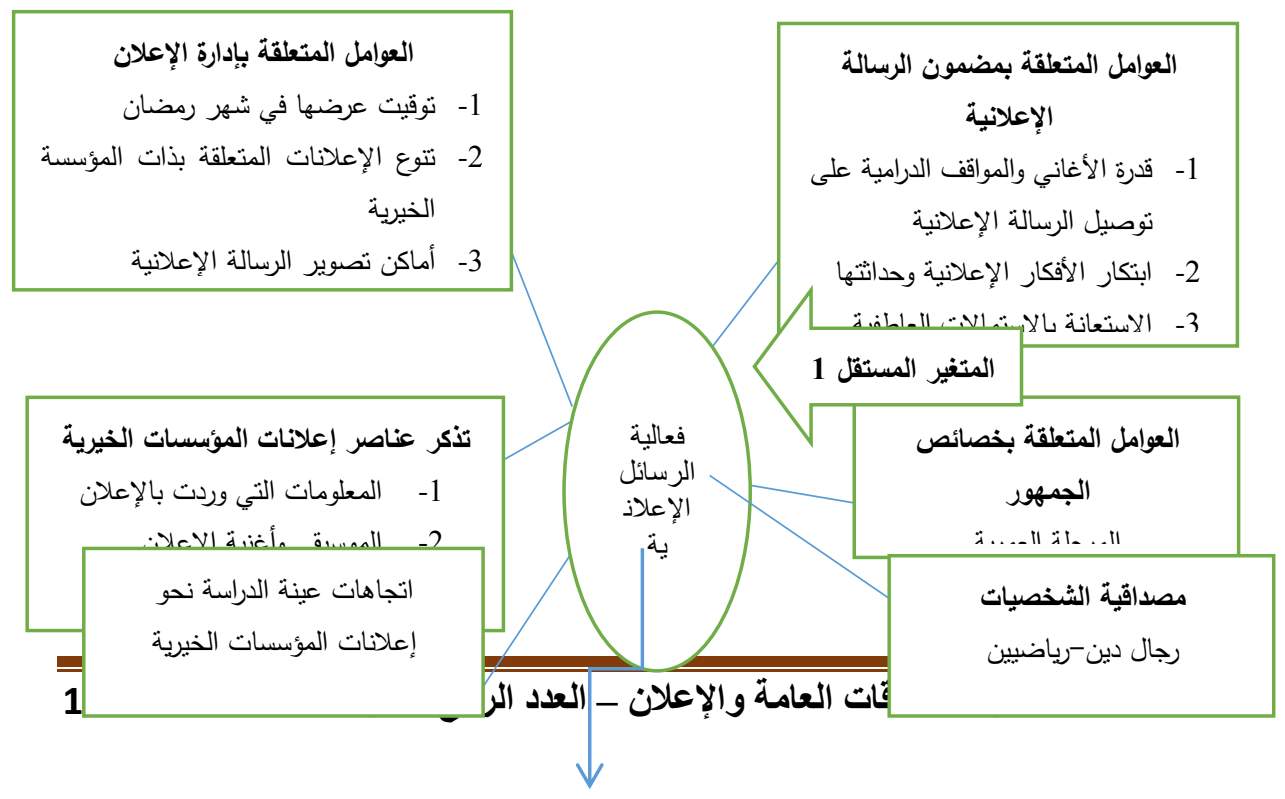




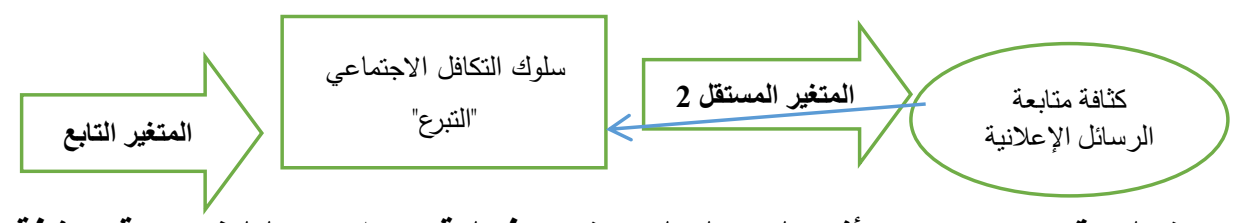

شكل رقم (18) نتائج تأثير العوامل التي تقيس فعالية الإعلانات التليفزيونية وكثافة التعرض لها على سلوك التبرع الته لأى الثباب المصري

\section{توصيات الدراسة:}

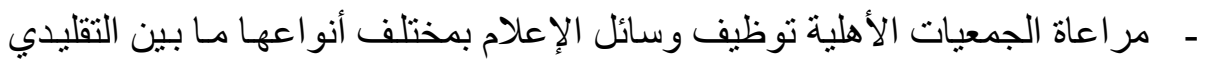

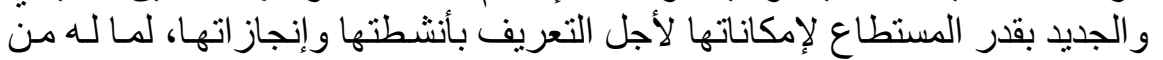

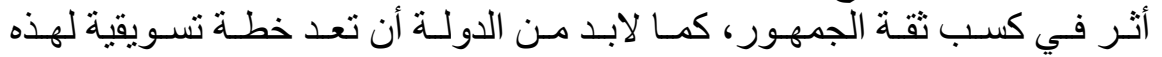
الجمعيات تساعدها في الاستفادة من إمكانـات الوسـائل الإعلاميـة المتاحـة مـع تقديم

$$
\text { دعم مالي. }
$$

تتظيم دور ات تدريبيـة للعـاملين بالمؤسسـات الخيريـة لتنميـة مهـار اتهم و إمكانـاتهم

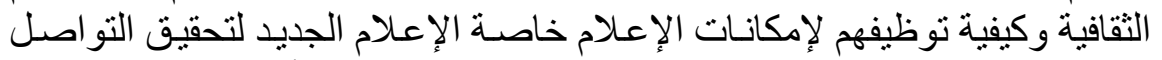

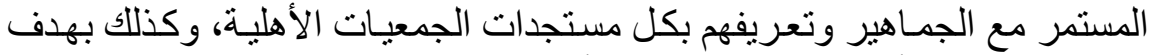

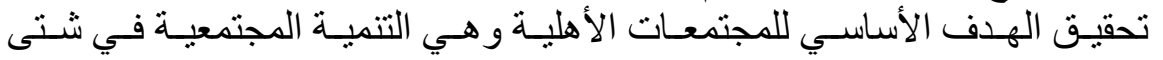
المجالات الحياتية.

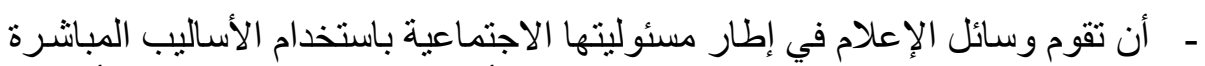

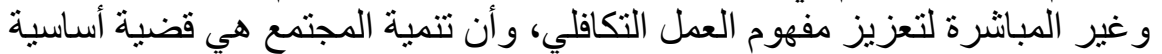

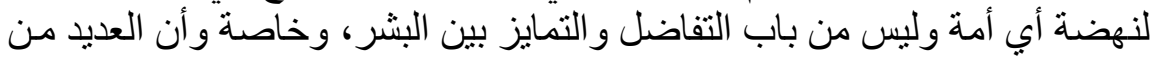

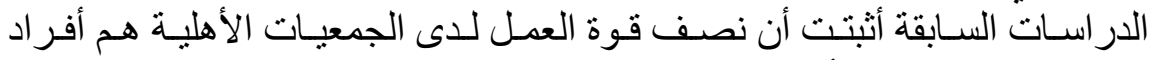
متطو عين مع اختلاف أنثكال التطوع لهن لهم.

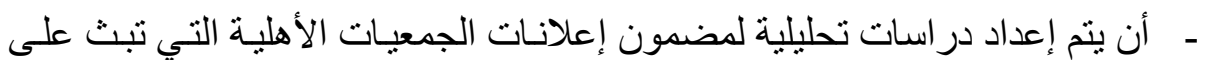

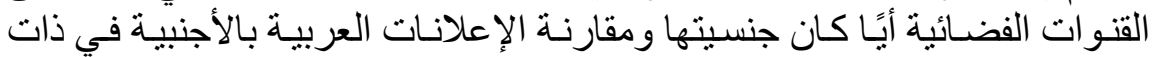

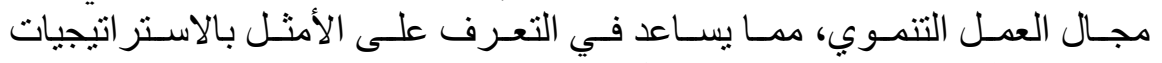
الاتصالية التي يتم تقديمها في الرسائل الإعلانية.

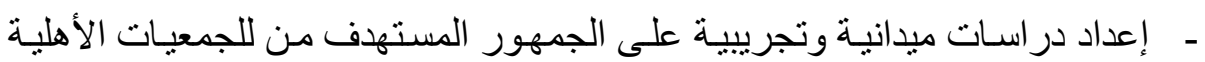

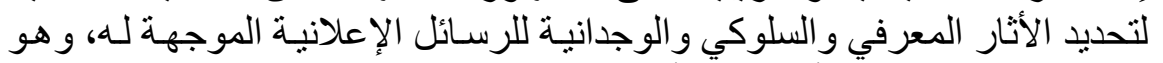
ما يساعد في التعرف الأمثل على أفضل الصياغات الصغل الإعلانية. 
تأثير عوامل الفعالية الإعلانية على سلوك التكافل الاجتماعي لاى الشباب المصري

- ت تنويع الأطر النظرية للار اسات المستهدفة لتقيم فعاليـة إعلانـات الجمعيـات الأهلية

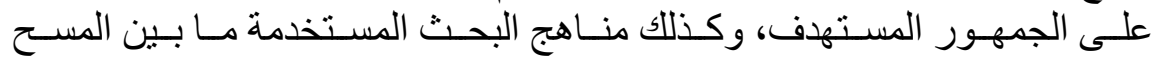
والتجريبي. 


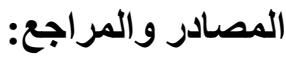

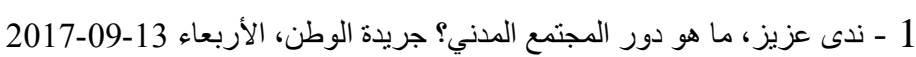

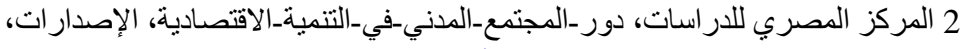

3 - علاء سالم، دور منظمات المجتمع المدني وخطط التنمية في مصر، ندوة بـ/20cpps.org/index.php/ar 2016/9/25، العدد

4 ـ الاتحاد العام للجمعيات و المؤسسات الأهلية. متاح على الر ابط التالي:

http://www.fngo.org.eg/NGO/News/View.aspx?ObjectID=9222

(5) خلف محمد البحيري. إعلانات الصحف والتربية المعلومانية لطلاب الجامعة: دراسة تحليلية ميدانية. في:

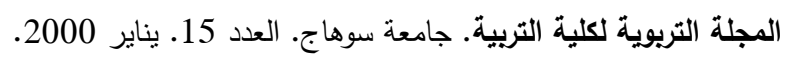

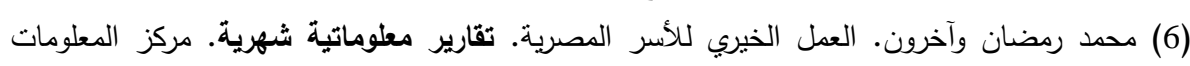

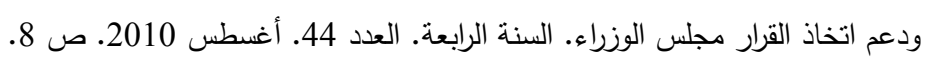

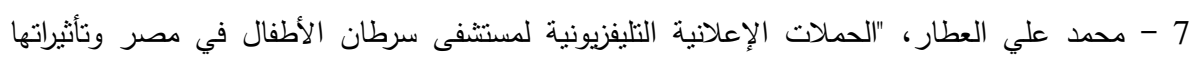

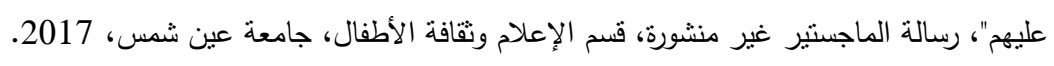

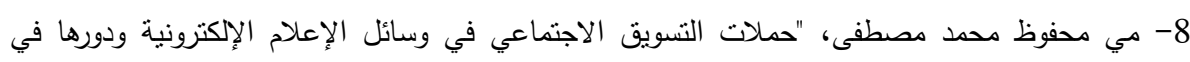

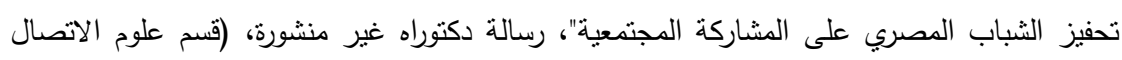

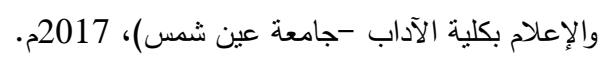

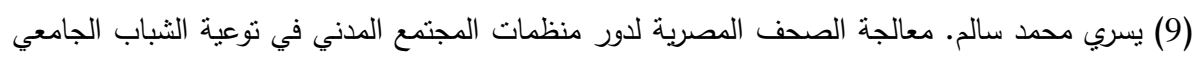
بحقوقهم: دراسة تحليلية وميدانية. رسالة دكتوراه غير منشورة. (جامعة المنصورة: كلية النربية النوعية.

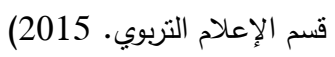

(10) ناهد شعبان محمد. دور الصحف في التسويق لأنشطة الجمعيات الأهلية: دراسة تحليلية مقارنة على العيل

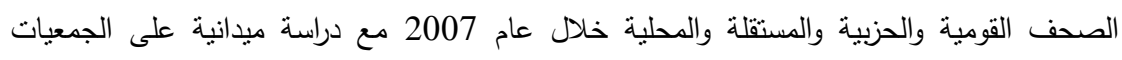
الأهلية بمحافظة سوهاج. رسالة ماجستير غير منشورة. (جامعة سوهاج: كلية الآداب. قسم الإعلام.

(11) محمد رمضان وآخرون. أوضاع الفقراء في مصر . تقرير شهري. مركز المعلومات ودعم اتخاذ القرار

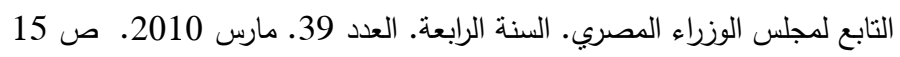

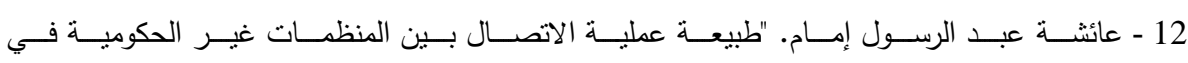

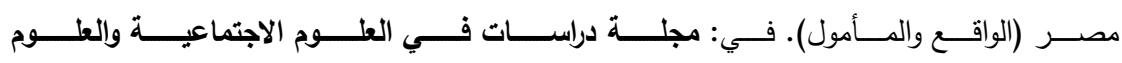

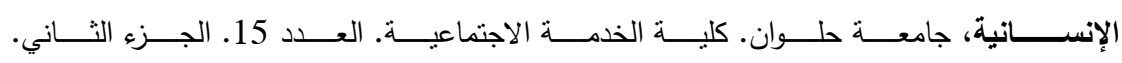

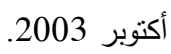




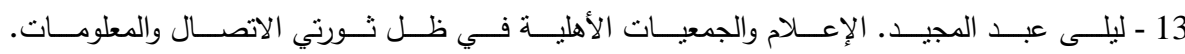

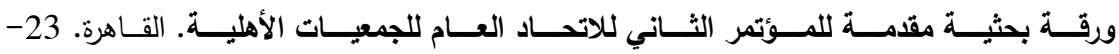

24

14-Zhang, Juyan. "Toward a Model of NGO Media Diplomacy in the Internet Age:

Case Study of 'The Washington Profile'" Paper presented at the annual meeting of the NCA 94th Annual Convention, TBA, San Diego, CA, Nov

20, 2008 .Available at: http:

//citation.allacademic.com/meta/p260309_index.html 2013-12-13

15- إيناس عبد الحميد الخريبي، الوظيفة الاتصالية لجمعيات تتمية المجتمع: دراسة ميدانية لعينة من جمعيات

تتمية المجتمع المحلي في الفترة من 1998-2000، رسالة ماجستير غير منشورة، (جامعة حلوان: كلية الآداب، قسم الإعلام، 2003).

16 - منى علي محمد عبد الرحمن. الأنثطة الاتصالية في مؤسسات المجتمع المدني: دراسة تطبيقية مقارنة

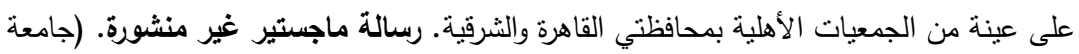

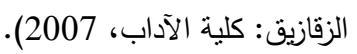

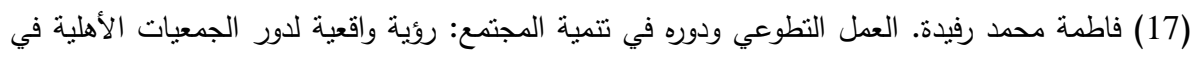

مدينة مصراته. مجلة كلية الآداب. جامعة مصراته. ليييا. العدد السادس.

.188

18 - محمد علي العطار ، "الحملات الإعلانية التليفزيونية لمستشفى سرطان الأطفال في مصر وتأثيراتها

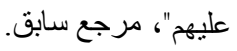

19 - سليمان صالح، الأمبود سمان ودوره في تحقيق علاقة متوازنة بين وسائل الإعلام والجمهور : دراسة

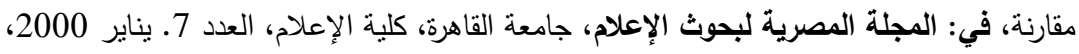

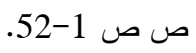

20- Bucy, Erickp. Living in the information age: Anew Media reader (Wadwortth:

Australia, United States, United Kingdom 2002) p. 289

(21) هبة نور الدين محمد. الإعلان التلفزيوني وأثره على نمط الاستهلاك الريفي. رسالة دكتوراه غير التهاي

منشورة. (جامعة عين شمس: كلية الزراعة. قسم المجتمع الريفي والإرشاد الزراعي. 2016).

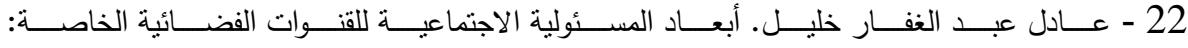

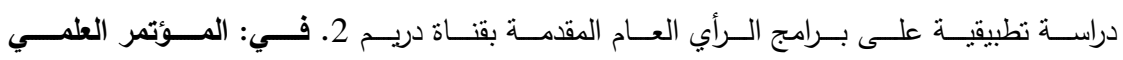

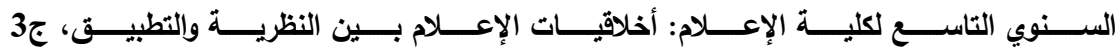

(القاهرة: كلية الإعلام، جامعة القاهرة، 2003) ص 751. 
(23) Al Anderson, H., An Empirical Investigation of What social Responsibility Theory Means, In. Journalism Quarterly, 1977, vol.54, p33 form: http://search.ebscohost.com/accessed on In: 28, May2011)

24 - Mcquail Dennis," Mass Communication Theory", 4th edition,(London: Sage publications, 2000) pp. 149-150

25 - Peter Bennett, Dictionary of Marketing Terms, (U.S.A: NTC publishing Group, 1995).

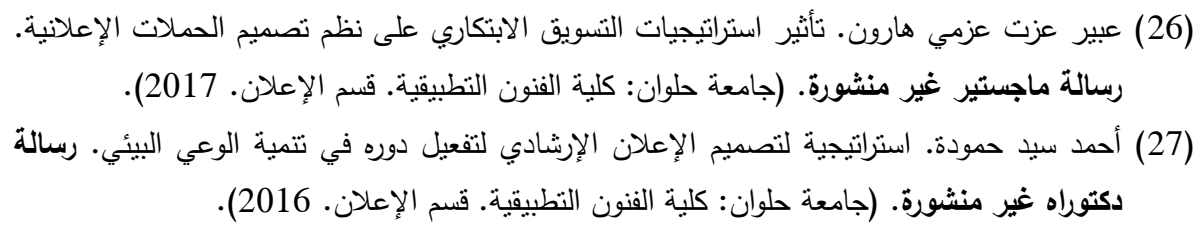

(28) Arthur-Mart. Trends in ethical advertising - a field study on the impact of the Declaration on the Conduce. In: Journal of current issue and research, Vol. 16, 2002. 
(34) عمر مقبول أحمد عبرين. استراتيجيات الإعلانات التليفزيونية الفضائية وأثرها على المستهلك في

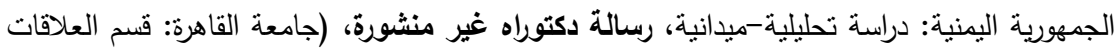

العامة والإعلان، 2009).

(35) حسن عماد مكاوي، ليلى حسين السيد. الاتصال ونظرياته المعاصرة. ط 6. (القاهرة: الدار المصرية

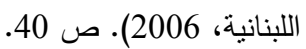

(36) عبد العزيز السيد عبد العزيز، مناهج البحث العلمي، (القاهرة: دار النهضة العربية للنشر، 2007)،

(37) محمد عبد الحميد. البحث العلمي في الاراسات الإعلامية. (القاهرة: عالم الكتب. 1997)، ص ص $.159-158$

(38) محمد رمضان وآخرون. العمل الخيري للأسر المصرية. تقارير معلوماتية شهرية. مركز المعلومات ودعم اتخاذ القرار مجلس الوزراء. السنة الرابعة. العدد 44. أغسطس ونس 2010. ص 8. (39) يسري محمد سالم. مرجع سابق. 2015.

(40) عاطف عدلي العبد. تصميم وتنفيذ لاستطلاعات ويحوث الرأي العام والإعلام: الأسس النظرية والنماذج التطبيقية. (القاهرة: دار الفكر العربي، 2002).

(41) فرج الكامل. بحوث الأعلام والرأي العام: تصميمها، وإجرائها، وتحليلها. ط1 (القاهرة: دار النشر

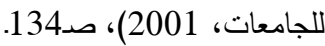

(42) بركات عبد العزيز. مقدمة في التحليل الإحصائي لبحوث الإعلام. ط1 (القاهرة: الدار المصرية اللبنانية. 2014). • تمثلت معادلة الانحدار الخطي البسيط: Y= A+ BX، وتفسير المعادلة كما يلي: - الرمز (y) يعبر عن المتغير التابع. - والرمز (X) يعبر عن المتغير المستقل.

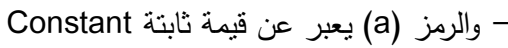
- يعبر عن ميل الانحدار y على المتغير المستقل. •تمثلت معادلة الانحدار الخطي المتعدد: e..... e كما يلي: - الرمز (y) - يعبر عن المتغير التابع. - والرمز (X1) يعبر عن المتغير المستقل الأول والذي يتعدد في حالة الانحدار المتعدد برمز (X2) و (X3) وهكذا. Constant يعبر عن قيمة ثابتة والرمز (a) - وا.ت - 
- والرمز (B1) يعبر عن ميل الانحدارy على المتغير المستقل الأول، والرمز (B2) يعبر عن ميل الانحدار ل على المتغير المستقل الثاني، وهكذا.

(43) جولي بالانت، ترجمة خالد العامري، التحليل الإحصائي باستخدام برامج "Spss"، ط2، (القاهرة: دار

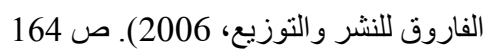

(44) آيات محمد عبد العاطي. تحليل الانحدار والارتباط الخطي المتعدد. (القاهرة: الجهاز المركزي للتعبئة

العامة والإحصاء. قطاع الإحصاءات السكانية والتعدادات. الإدارة المركزية للتدريب الإحصائي.

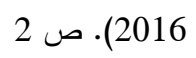

(45) غادة محمد عبد السلام. الارتباط والانحار الخطي البسيط. (القاهرة: الجهاز المركزي للتعبئة العامة

والإحصاء. قطاع الإحصاءات السكانية والتعدادات. الإدارة المركزية للنتريب الإحصائي. 2015).

2 ص 2

(46) إيمان سعد بسيوني بليح. تأثير الحملات الإعلانية الحكومية التلفزيونية على الجمهور المصري: دراسة

نطبيقة. رسالة ماجستير غير منشورة. (جامعة الزقازيق: كلية الآداب. قسم الإعلام. 2015).

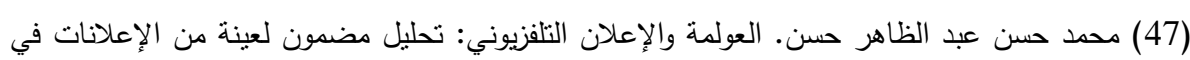

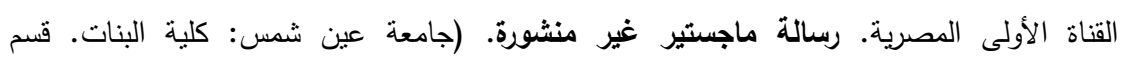

الاجنماع. 2008).

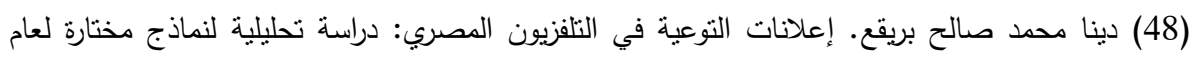

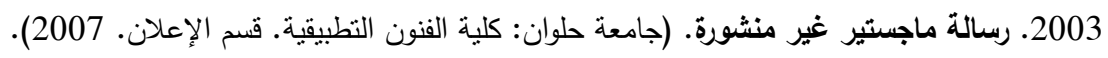

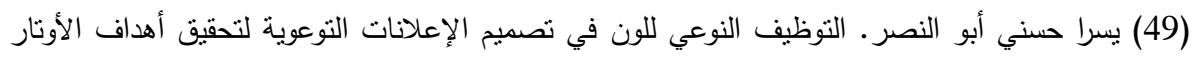

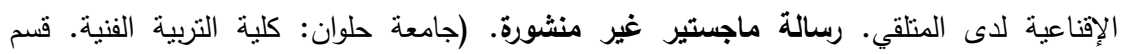

التصميمات الزخرفية. 2016).

(50) هبة نور الدين محمد. مرجع سابق. 2016.

(51) مسعود حسين التايب. أخلاقيات الإعلان في القنوات الفضائية العربية: دراسة تحليلية وصفية لقناتى

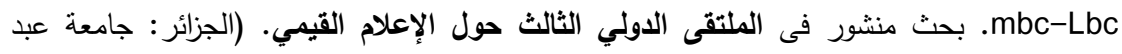

الحميد ابن باديس،10 - 11 مارس 2015).

(52) حسن نيازي الصيفي أبو العلا. أخلافيات الإعلان في الفضائيات العربية. رسالة دكتوراه غير منشورة.

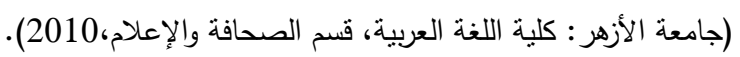

(53) منار محمد يحيي. توظيف الثخصيات الثهيرة في الإعلان لتحقيق الأهداف الاتصالية. رسالة

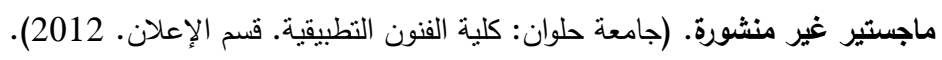

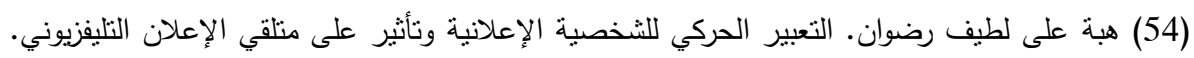

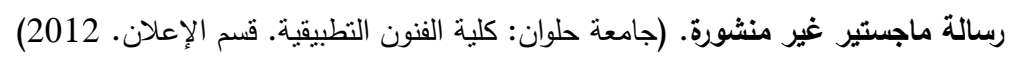




$$
\begin{aligned}
& \text { (55) نيفين محمد حسن محمد عبد العزيز. التأثير البصري في إعلان الواقع الافتراضي وأثره على الدنلقي. }
\end{aligned}
$$

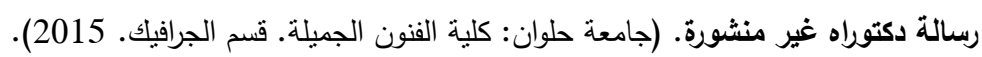

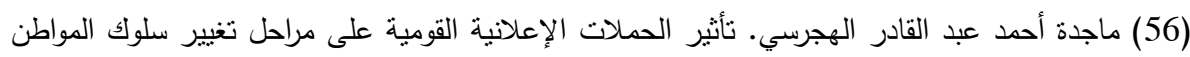

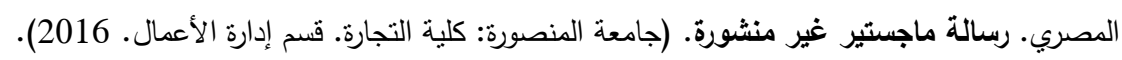

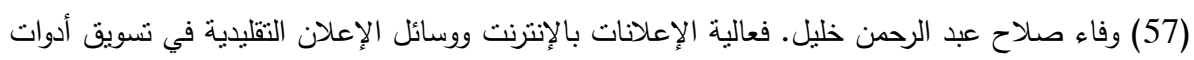

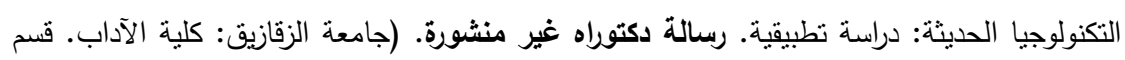

$$
\begin{aligned}
& \text { الإعلام. 2013). }
\end{aligned}
$$

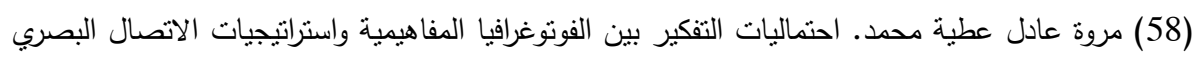

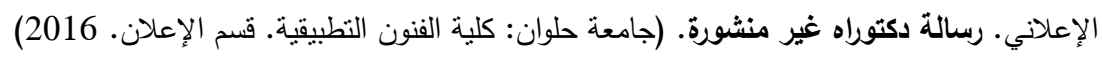

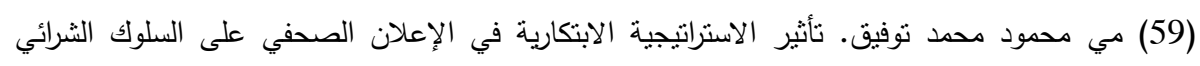

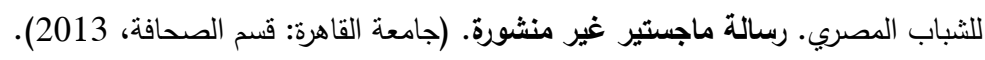

(60) Magdalena Tsoutsoump. Audience Reception of Charity Advertising: Making Sense, Interpreting and Decoding Advertisements That Focus on Human Suffering. London School of Economics and Political Science ('LSE'), 2013.

(2) Burt \& K Strongman. ,(2013), -CDB Use of images in Charity advertising: improving donations and compliance rates, http://www.google.com.eg/ cu.jp\%Fpapers\%2F168 1b.pdf\&ei=2QttU6S1Dev70gX4z4D4DQ.

(62) عاطف على أحمد عبد العال. دور الأنثطة الإعلامية المقدمة بالمؤسسات والجمعيات الأهلية في تثقيف المراهقين المصريين. رسالة ماجستير غير منشورة. (جامعة عين شمس: معهد الدراسات العليا للطفولة. قسم الإعلام وثقافة الأطفال. 2015) 63 - محمد سيد عتران. "الدور الاتصالي لمنظمات المجتمع المدني الخدمية في معالجة مشكلات الفقراء".

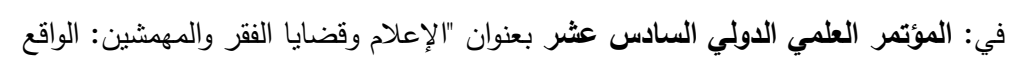

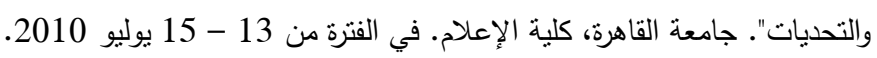

(4) Bendell, D. and Walker, L. and Curl, D, Business support approaches for charities and other non-profiles, in: International Journal Of Non Profit And Voluntary Sector Marketing. vol.6, 2001. P.172

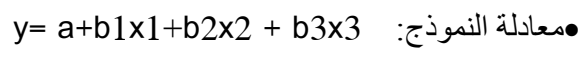

$$
\begin{aligned}
& 65 \text { - إيناس عبد الحميد الخريبي، مرجع سابق، } 2003 \text { معرد3 }
\end{aligned}
$$

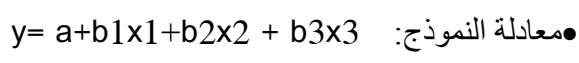


(66)David Hudson. Jennifer vanHeerde-Hudson. Niheer Dasandi. N. Susan Gaines. Emotional Pathways to Engagement with Global Poverty: An Experimental Analysis. paper was presented at the 2015 Annual Meeting of the American Political Science Association. April 24, 2016

$$
\begin{aligned}
& \text { •معادلة النموذج: } \\
& \text { •معادلة النموذج: }
\end{aligned}
$$

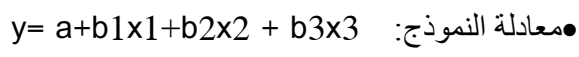

$$
\begin{aligned}
& 67 \text { - حسن نبازي الصيفي أبو العلا. مرجع سابق،2010 }
\end{aligned}
$$

